Prepared in cooperation with the Town of Framingham, Massachusetts

\title{
Simulation of Groundwater and Surface-Water Interaction and Effects of Pumping in a Complex Glacial-Sediment Aquifer, East Central Massachusetts
}

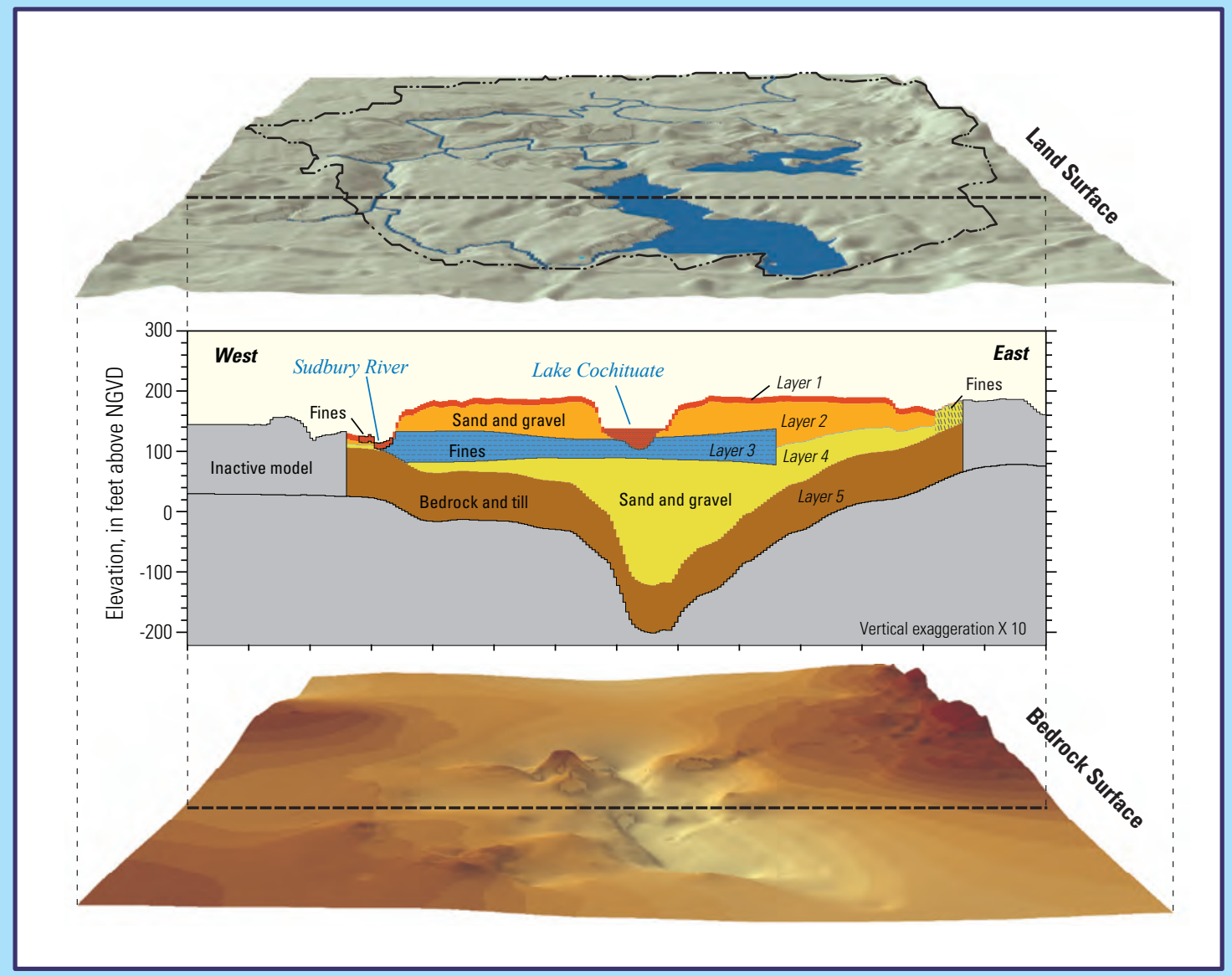

Scientific Investigations Report 2012-5172 
Cover. Oblique view of the land topography and bedrock surfaces, and a cross section of the model layers between the surfaces. 


\section{Simulation of Groundwater and Surface- Water Interaction and Effects of Pumping in a Complex Glacial-Sediment Aquifer, East Central Massachusetts}

By Jack R. Eggleston, Carl S. Carlson, Gillian M. Fairchild, and Phillip J. Zarriello

Prepared in cooperation with the Town of Framingham, Massachusetts

Scientific Investigations Report 2012-5172 


\title{
U.S. Department of the Interior \\ KEN SALAZAR, Secretary \\ U.S. Geological Survey \\ Marcia K. McNutt, Director
}

\author{
U.S. Geological Survey, Reston, Virginia: 2012
}

For more information on the USGS - the Federal source for science about the Earth, its natural and living resources, natural hazards, and the environment, visit http://www.usgs.gov or call 1-888-ASK-USGS.

For an overview of USGS information products, including maps, imagery, and publications, visit http://www.usgs.gov/pubprod

To order this and other USGS information products, visit http://store.usgs.gov

Any use of trade, firm, or product names is for descriptive purposes only and does not imply endorsement by the U.S. Government.

Although this information product, for the most part, is in the public domain, it also may contain copyrighted materials as noted in the text. Permission to reproduce copyrighted items must be secured from the copyright owner.

Suggested citation:

Eggleston, J.R., Carlson, C.S., Fairchild, G.M., and Zarriello, P.J., 2012, Simulation of groundwater and surface-water interaction and effects of pumping in a complex glacial-sediment aquifer, east central Massachusetts: U.S. Geological Survey Scientific Investigations Report 2012-5172, 48 p. (Also available at http://pubs.usgs.gov/sir/2012/5172/.) 


\section{Acknowledgments}

A stakeholder interest group assembled for the study provided feedback and guided selection of model scenarios that were examined by the U.S. Geological Survey. Members of the stakeholder interest group include representatives from the towns of Framingham and Wayland, Massachusetts Water Resources Authority (MWRA), Massachusetts Department of Environmental Protection and Department of Conservation and Recreation, Massachusetts Executive Office of Environmental Affairs, U.S. Fish and Wildlife Service, U.S. Environmental Protection Agency, National Park Service, Organization for the Assabet River, Water Supply Citizens Advisory Committee, and SuAsCo (Sudbury-Assabet-Concord) Watershed Community Council. A separate technical advisory committee provided scientific oversight and technical guidance to the study and included the following non-USGS members: David Ahlfeld (University of Massachusetts), Grant Garven (Tufts University), and Daniel Nvule (MWRA). The authors gratefully acknowledge the guidance from the stakeholders' interest group and the technical advisory committee.

Rich Niswonger of the USGS provided valuable assistance in development of the MODFLOWNWT model, and Janet Stone and Byron Stone of the USGS substantially improved our understanding of glacial sedimentology at the site. The authors also extend special thanks to Peter Newton of Bristol Engineering Advisors, Inc., for his involvement in various aspects of the study ranging from sharing his knowledge of the study area to collecting field information used in the study. 
THIS PAGE INTENTIONALLY LEFT BLANK 


\section{Contents}

Acknowledgments ..................................................................................................................ii

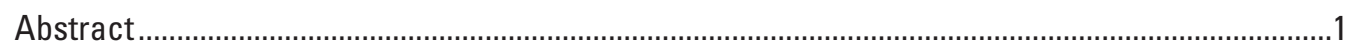

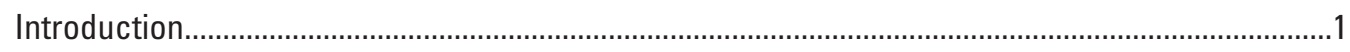

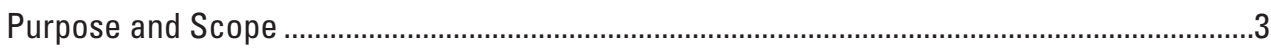

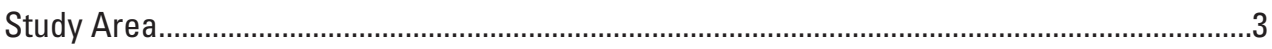

Previous Investigations.....................................................................................................

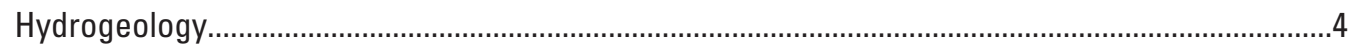

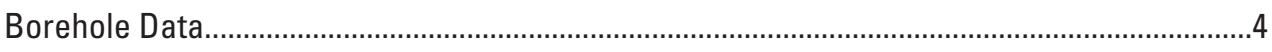

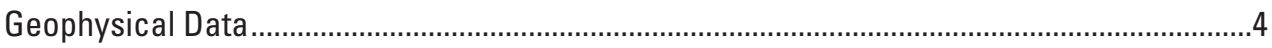

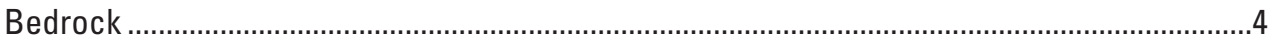

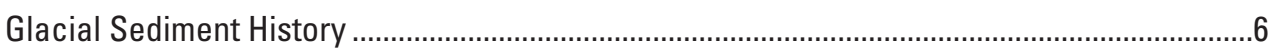

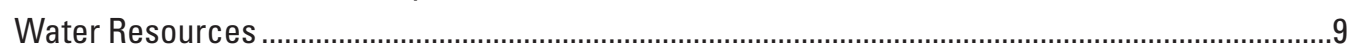

Surface-Water Features.............................................................................................

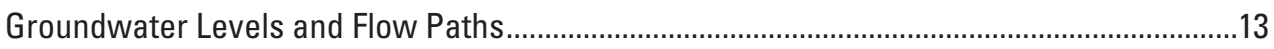

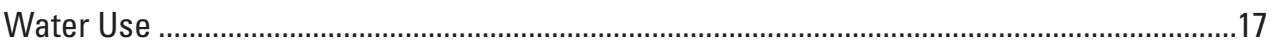

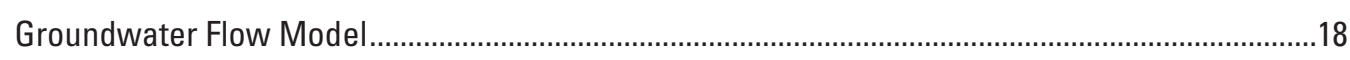

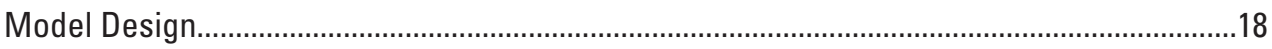

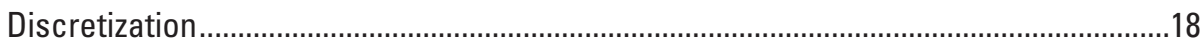

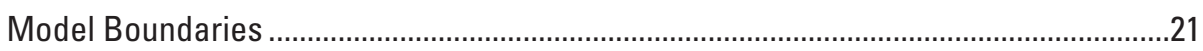

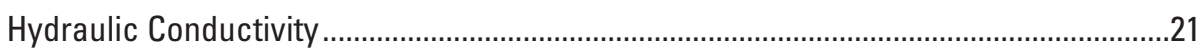

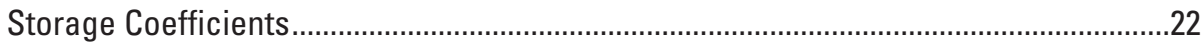

Streams

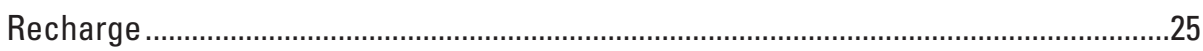

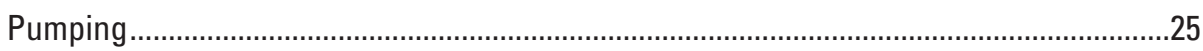

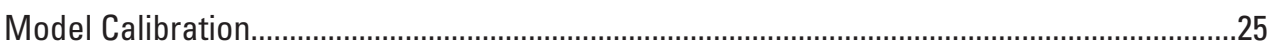

Steady-State Calibration ........................................................................................25

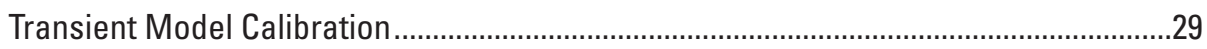

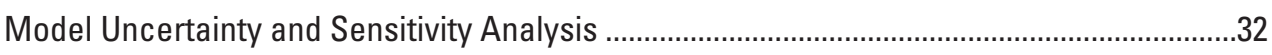

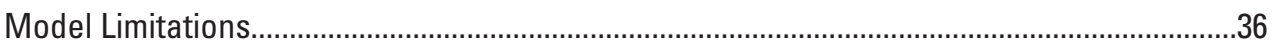

Simulated Aquifer and Streamflow Response ……..............................................................

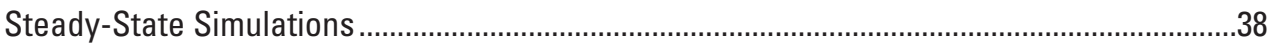

Transient Model Simulations ....................................................................................................

Evaluation of Pumping Strategies to Reduce Low-Flow Stresses ........................................40

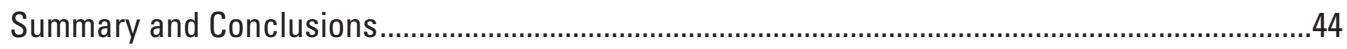

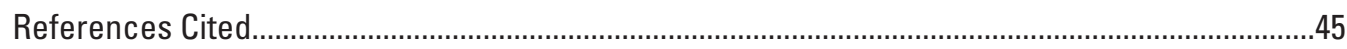




\section{Figures}

1. Map showing glacial-sediment aquifer study area in east central Massachusetts ........2

2. Map showing well borings to bedrock, bedrock outcrops, passive seismic points, and seismic lines used to develop the hydrogeologic framework and bedrock surface topography, east central Massachusetts

3. Graphs showing passive seismic $A$, response resonance frequency at known bedrock depths and $B$, estimated and observed bedrock depths, east central Massachusetts.

4. Map showing thickness of sediments above the bedrock surface in the study area, east central Massachusetts

5. Map showing locations of glacial-sediment deposits in the study area, east central Massachusetts.

6. Hydrogeologic cross sections running north-south $\left(A-A^{\prime}\right.$ and $\left.B-B^{\prime}\right)$ and east-west ( $C-C^{\prime}$ and $\left.D-D^{\prime}\right)$ through the study area, east central Massachusetts .10

7. Map showing surface-water features and interpolated groundwater table elevations in the study area, east central Massachusetts

8. Photograph of Pod Meadow Pond showing open water along the southern shore in February 2011, Framingham, Massachusetts

9. Map showing active model area and boundary conditions, east central Massachusetts

10. Maps showing variability of hydraulic conductivity values of groundwater-model layers 1-4 used in the calibrated model, east central Massachusetts.

11. Vertical cross sections of groundwater model layers and hydraulic conductivity values running $A$, north-south and $B$, east-west, east central Massachusetts

12. Maps showing model cells in layers $1-4$ that dry in the calibrated steady-state model, east central Massachusetts

13. Graph showing observed and steady-state simulated groundwater levels, east central Massachusetts

14. Map showing simulated steady-state groundwater levels and errors, east central Massachusetts

15. Map showing wells used for transient model calibration of a glacial-sediment aquifer model in east central Massachusetts

16. Simulated and observed groundwater hydrographs, under current conditions and no pumping at the Birch Road wells, east central Massachusetts

17. Graph showing transient simulation of a 2006 aquifer test made with a daily time step compared to groundwater observations, east central Massachusetts

18. Map showing baseflow reduction (streamflow depletion) in stream-channel segments in response to simulated pumping at the Birch Road wells at a constant rate of 4.9 cubic feet per second (3.17 million gallons per day), east central Massachusetts.

19. Graph showing simulated transient monthly water budget under current average monthly conditions (no pumping of Birch Road wells), east central Massachusetts.....40

20. Graph showing simulated streamflow response of the Sudbury River after 1 month of pumping the Birch Road wells at 4.9 cubic feet per second ( 3.17 million gallons per day), east central Massachusetts

21. Graph showing simulated monthly streamflows in the Sudbury River at the model exit under five hypothetical pumping scenarios for the Birch Road wells, east central Massachusetts 
22. Graph showing simulated streamflow along the Sudbury River for the month of September under average recharge rates and various pumping durations at the

Birch Road wells, east central Massachusetts.

23. Graph showing percent reduction in Sudbury River simulated streamflow at the model exit in response to pumping under average and dry recharge conditions, east central Massachusetts

\section{Tables}

1. Discharge measurements at the outflows from Pod Meadow Pond and Dudley

Pond, east central Massachusetts

2. Borehole and groundwater observation wells used in the study, east central Massachusetts.

3. Average groundwater withdrawal rates from Wayland production wells, 1996-2000 and 2002-2006, Wayland, Massachusetts.

4. Hydraulic conductivity of aquifer material and storage coefficients by layer in the calibrated model, east central Massachusetts.

5. Stream segments and properties in the groundwater flow model, east central Massachusetts.

6. Monthly recharge rates used in the transient groundwater flow model.

7. MODFLOW-NWT input file variable values for NWT package for transient simulations of current conditions (scenario 4)

8. Hydrologic characteristics and observed and simulated water levels of Pod Meadow Pond, Dudley Pond, and Lake Cochituate, east central Massachusetts .........26

9. Simulated flows between Pod Meadow Pond, Dudley Pond, and Lake Cochituate and the aquifer, east central Massachusetts

10. Observed and simulated water levels and drawdowns from aquifer test of the Birch Road wells, east central Massachusetts...

11. Model simulations used to determine sensitivity of induced recharge from Lake Cochituate and pumping response times to hydraulic parameter values, east central Massachusetts.

12. Changes in induced recharge from Lake Cochituate and streamflow response times resulting from changes in hydraulic parameter values, east central Massachusetts.

13. Groundwater model scenarios used to evaluate the aquifer and streamflow response to hypothetical withdrawals at the Birch Road wells, east central Massachusetts.

14. Steady-state simulated water budgets with and without hypothetical Birch Road well withdrawals, east central Massachusetts

15. Simulated monthly flow in the Sudbury River under different hypothetical pumping scenarios for the Birch Road wells, east central Massachusetts. 


\section{Conversion Factors, Datum, and Abbreviations}

Inch/Pound to SI

\begin{tabular}{lcl}
\hline \multicolumn{1}{c}{ Multiply } & By & \multicolumn{1}{c}{ To obtain } \\
\hline foot $(\mathrm{ft})$ & Length & \\
mile (mi) & 0.3048 & meter $(\mathrm{m})$ \\
inch (in.) & 1.609 & kilometer $(\mathrm{km})$ \\
\hline & 2.54 & centimeter $(\mathrm{cm})$ \\
\hline square mile $\left(\mathrm{mi}^{2}\right)$ & Area & \\
\hline & 2.590 & square kilometer $\left(\mathrm{km}^{2}\right)$ \\
\hline cubic foot per day $\left(\mathrm{ft}^{3} / \mathrm{d}\right)$ & Flow rate & \\
cubic foot per second $\left(\mathrm{ft}{ }^{3} / \mathrm{s}\right)$ & 0.00001157 & cubic foot per second $\left(\mathrm{ft}^{3} / \mathrm{sec}^{2}\right)$ \\
million gallons per day $(\mathrm{Mgal} / \mathrm{d})$ & 0.6463 & million gallons per day $(\mathrm{Mgal} / \mathrm{d})$ \\
\hline
\end{tabular}

Vertical coordinate information is referenced to the North American Vertical Datum of 1988 (NAVD 88).

Horizontal coordinate information is referenced to the North American Datum of 1983 (NAD 83).

'Elevation', as used in this report, refers to distance above the vertical datum (NAVD 88).

\section{Abbreviations}

$\begin{array}{ll}\text { EIR } & \text { Environmental Impact Report } \\ \text { MassDEP } & \text { Massachusetts Department of Environmental Protection } \\ \text { MassDCR } & \text { Massachusetts Department of Conservation and Recreation } \\ \text { MEPA } & \text { Massachusetts Environmental Policy Act } \\ \text { MODFLOW-NWT } & \text { MODular Groundwater FLOW Model with NeWTonian Solver } \\ \text { MWRA } & \text { Massachusetts Water Resources Authority } \\ \text { NOAA } & \text { National Oceanic and Atmospheric Administration } \\ \text { NPS } & \text { National Park Service } \\ \text { NWIS } & \text { National Water Information System } \\ \text { Ss } & \text { Specific storage } \\ \text { Sy } & \text { Specific yield } \\ \text { USFWS } & \text { U.S. Fish and Wildlife Service } \\ \text { USEPA } & \text { U.S. Environmental Protection Agency } \\ \text { USGS } & \text { U.S. Geological Survey }\end{array}$




\title{
Simulation of Groundwater and Surface-Water Interaction and Effects of Pumping in a Complex Glacial-Sediment Aquifer, East Central Massachusetts
}

\author{
By John R. Eggleston, Carl S. Carlson, Gillian M. Fairchild, and Phillip J. Zarriello
}

\section{Abstract}

The effects of groundwater pumping on surface-water features were evaluated by use of a numerical groundwater model developed for a complex glacial-sediment aquifer in northeastern Framingham, Massachusetts, and parts of surrounding towns. The aquifer is composed of sand, gravel, silt, and clay glacial-fill sediments up to 270 feet thick over an irregular fractured bedrock surface. Surface-water bodies, including Cochituate Brook, the Sudbury River, Lake Cochituate, Dudley Pond, and adjoining wetlands, are in hydraulic connection with the aquifer and can be affected by groundwater withdrawals.

Groundwater and surface-water interaction was simulated with MODFLOW-NWT under current conditions and a variety of hypothetical pumping conditions. Simulations of hypothetical pumping at reactivated water supply wells indicate that captured groundwater would decrease baseflow to the Sudbury River and induce recharge from Lake Cochituate. Under constant (steady-state) pumping, induced groundwater recharge from Lake Cochituate was equal to about 32 percent of the simulated pumping rate, and flow downstream in the Sudbury River decreased at the same rate as pumping. However, surface water responded quickly to pumping stresses. When pumping was simulated for 1 month and then stopped, streamflow depletions decreased by about 80 percent within 2 months and by about 90 percent within about 4 months. The fast surface water response to groundwater pumping offers the potential to substantially reduce streamflow depletions during periods of low flow, which are of greatest concern to the ecological integrity of the river. Results indicate that streamflow depletion during September, typically the month of lowest flow, can be reduced by 29 percent by lowering the maximum pumping rates to near zero during September. Lowering pumping rates for 3 months (July through September) reduces streamflow depletion during September by 79 percent as compared to constant pumping. These results demonstrate that a seasonal or streamflow-based groundwater pumping schedule can reduce the effects of pumping during periods of low flow.

\section{Introduction}

Glacial-sediment aquifers are an important source of water to communities in the northeastern United States. However, groundwater withdrawals from these aquifers are of growing concern because of their potential effects on surface-water resources, particularly streamflows. In the past, groundwater withdrawal limits were based on aquifer tests that determined the potential yield from wells with little regard to the effects of pumping on surface waters in hydraulic connection to the aquifer. More recent approaches to determining acceptable groundwater withdrawal rates include evaluating the long-term consequences of pumping on surface water resources and related ecosystems (Gleeson and others, 2011). The potential effects of groundwater withdrawals on surfacewater features recently gained attention when the Town of Framingham (fig. 1) sought to reactivate production wells (the Birch Road wells) that previously provided a local water supply from 1939 until about 1979. The wells were discontinued because of high iron and manganese concentrations and the availability of an alternative regional water supply.

In 2009, in accordance with the Massachusetts Environmental Policy Act (MEPA), the Town of Framingham filed an Environmental Impact Report (EIR) to reactivate the wells (SEA Consultants, Inc., 2009). Letters of concern over the well reactivation were submitted during the MEPA process by the National Park Service (NPS), the U.S. Fish and Wildlife Service (USFWS), the U.S. Environmental Protection Agency (USEPA), and the Office of the Solicitor for the U.S. Department of the Interior that specifically addresses Federal interests in the Sudbury River and the downstream Concord River corridors. Federal agency concerns were raised because the Sudbury River, which is near the proposed pumping wells, is designated by Congress as "Wild and Scenic," requiring special resource protection. In addition, the river corridor includes the Great Meadows National Wildlife Refuge and the Minute Man National Historical Park. Of these, the Great Meadows National Wildlife Refuge is of particular concern because of its proximity to the Birch Road wells and its primary purpose to protect river and wetland habitats 


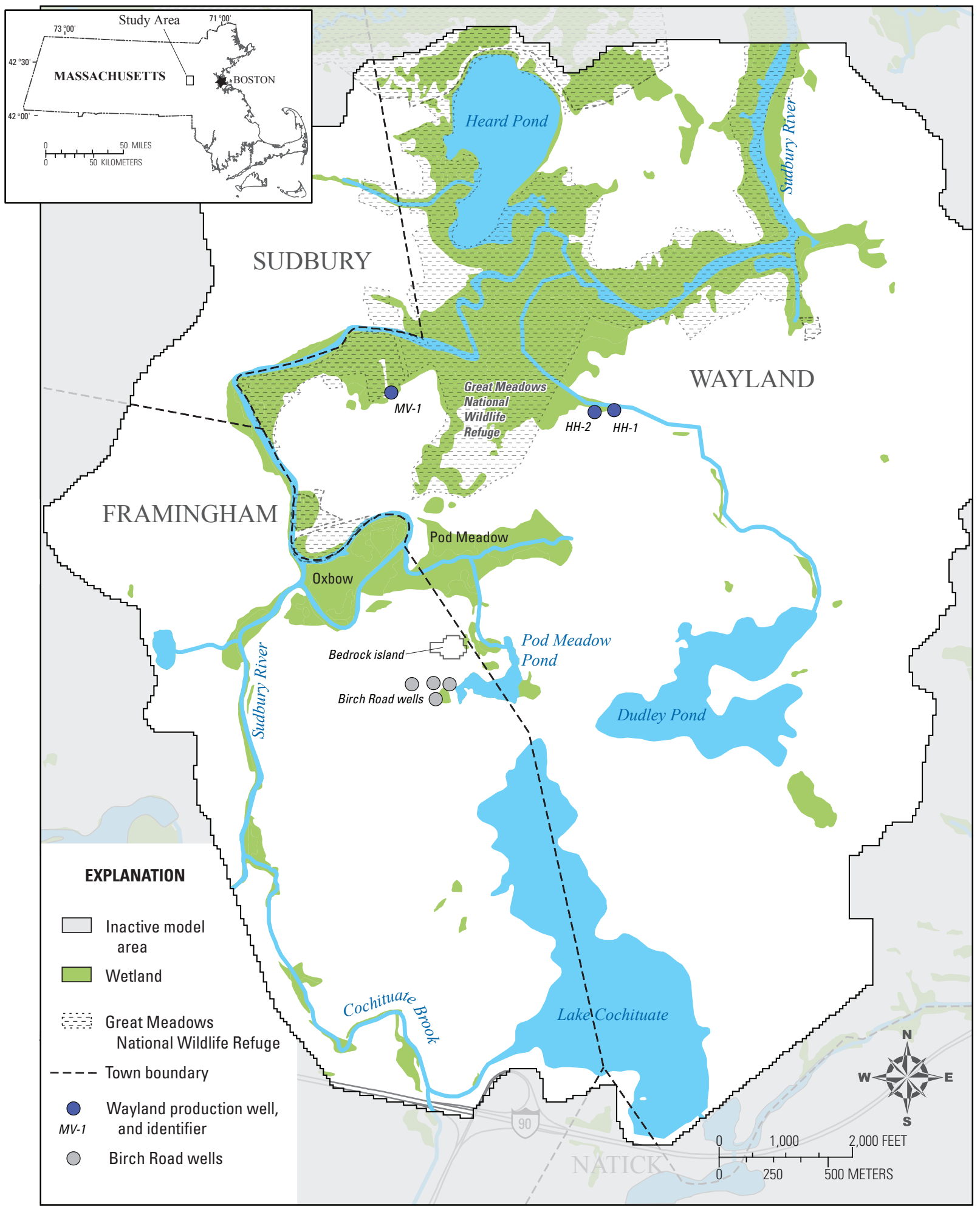

Base from U.S. Geological Survey and Massachusetts Geographic Information System data sources,

Massachusetts State Plane Coordinate System, Mainland Zone

Figure 1. Glacial-sediment aquifer study area in east central Massachusetts. 
for migratory birds, fish, and other wildlife. In addition, environmental concerns were expressed in the MEPA review by state agencies, municipal agencies, and environmental interest groups, particularly about the effects of pumping on nearby Lake Cochituate, a state recreational resource.

The Sudbury River is considered stressed, particularly in its headwater reaches during low-flow periods, by development pressures and by numerous groundwater and surfacewater withdrawals that affect streamflows (Zarriello and others, 2010). Concern about potential impacts of additional groundwater withdrawals on surface-water resources and aquatic ecology has led to a need for better understanding of the hydrologic system in the area of the proposed pumping. The purpose of this study by the U.S. Geological Survey (USGS), made in cooperation with the Town of Framingham, is to contribute to that understanding by presenting a compilation of existing and new hydrogeologic data and a new groundwater simulation model that was used to assess interactions between groundwater and surface water. The purpose of the groundwater model is to simulate present and hypothetical pumping conditions and to assess the potential to manage groundwater pumping to minimize its effect on nearby surface-water features. Hydraulic connections between surface water and aquifers are a growing concern across the country, and the techniques used in this study contribute to balancing the competing demands of water-supply needs with naturalresource protection, particularly in glacial-sediment aquifers in the northeastern United States.

\section{Purpose and Scope}

This report describes the development and calibration of a MODFLOW-NWT (Niswonger and others, 2011) groundwater model of the aquifer surrounding the Birch Road well site in Framingham, Massachusetts. The report also describes use of the model to simulate interaction between groundwater and surface-water features in the area under present conditions and scenarios of potential pumping from the Birch Road wells. The scenarios include alternative pumping rates and schedules that could reduce the effects of additional groundwater withdrawals on streams during low flows when the effects of withdrawals are most pronounced.

\section{Study Area}

The study area is 16 miles (mi) west of Boston in east central Massachusetts (fig. 1). The active groundwater model area covers about 6.1 square miles $\left(\mathrm{mi}^{2}\right)$ surrounding the Birch Road wells in the towns of Framingham $\left(1.7 \mathrm{mi}^{2}\right)$, Wayland $\left(4.0 \mathrm{mi}^{2}\right)$, Sudbury $\left(0.4 \mathrm{mi}^{2}\right)$, and Natick $\left(0.01 \mathrm{mi}^{2}\right)$.

The Sudbury River is the primary surface-water drainage feature, entering the study area from the southwest and discharging to the northeast. The Great Meadows National Wildlife Refuge (fig. 1) includes lands adjacent to the Sudbury River north of the oxbow and wetland areas in the northern part of the study area, although most of the refuge is to the north of the study area. Lake Cochituate is the largest water body in the study area and has a $17.5 \mathrm{mi}^{2}$ watershed that is largely to the south and west of the study area. Lake Cochituate drains to the Sudbury River through the $1.4 \mathrm{mi}$ long Cochituate Brook. Additional surface-water bodies include Dudley Pond, Pod Meadow Pond, and Heard Pond, which drain to the Sudbury River.

The aquifer is a complex mix of stratified glacially deposited sediments, including meltwater deltaic deposits and proglacial lake deposits that range in texture from clay to coarse gravel and boulders. Most of these deposits are medium to fine sands, which are the primary aquifer deposits.

\section{Previous Investigations}

The hydrology of the Lake Cochituate area was described by Gay (1985). Surficial geology of the study area was first described by Nelson $(1974 b$, c) for the Framingham and Natick quadrangles and later updated by Stone and Stone (2006). Bedrock geology was described by Nelson (1974a, 1975) and updated by Zen and others (1983). Pond-aquifer interaction for the South Pond part of Lake Cochituate (south of the area shown in fig. 1) was investigated by Friesz and Church (2001). A hydrologic watershed model of the Sudbury and Assabet River basins was developed by Zarriello and others (2010) to simulate effects of water use and land use.

A variety of engineering consulting reports were published leading up to construction of the Massachusetts Water Resources Authority (MWRA) Metrowest watersupply tunnel that passes beneath the study area (Balsam Environmental Consultants 1986, 1987, and 1992). Seismic data were collected between 1989 and 1994 by GZA GeoEnvironmental, Inc. (1995). Aquifer characteristics, aquifer tests, and a one-layer groundwater model for the Birch Road well area were described by SEA Consultants, Inc., $(1992,2008)$ to evaluate reactivation of the Birch Road wells. Other observation wells and aquifer characteristics were described during investigations of nearby groundwater contamination (Sovereign Consulting, Inc., 2009; URS Corporation, 2003; IEP, Inc., 1983; Haley \& Aldrich, 1996).

The Assabet-Sudbury River Basin study (Zarriello and others, 2010) includes end-member simulations of the effect of constant withdrawals from the Birch Road wells on river flow and Lake Cochituate water levels under assumed contribution or depletion of water from different surface-water sources. Hypothetical pumping was simulated at a constant rate of 6.65 cubic feet per second $\left(\mathrm{ft}^{3} / \mathrm{s}\right)$, with water coming from Lake Cochituate, the Sudbury River, or combinations of these sources to determine changes in lake level and river flow. Simulation results indicated that reactivation of the Birch Road wells could cause flows in the Sudbury River and Cochituate Brook to be "substantially affected during periods of low flow" (Zarriello and others, 2010). The authors note that "if pumping rates were varied, the effects on lake stage 
and flow could be mitigated if withdrawals were decreased at the appropriate times and by the appropriate amounts." The current study looks at that possibility in greater detail.

\section{Hydrogeology}

Land surface elevations in the study area range from about 300 feet ( $\mathrm{ft}$ ) on the eastern margin to about $115 \mathrm{ft}$ at the northeast outlet of the Sudbury River. Glacial-sediment deposits with complex stratification blanket a highly variable bedrock surface and fill a deep bedrock valley that underlies the north-south axis of Lake Cochituate. An understanding of the regional stratigraphic framework, geotechnical sediment classifications, and geologic depositional processes responsible for aquifer structure helps to appropriately represent the aquifer system in a groundwater flow model.

\section{Borehole Data}

Borehole data were compiled from consultant reports (Balsam Environmental Consultants, 1986, 1987, and 1992; GZA GeoEnvironmental, Inc., 1995; Haley \& Aldrich, 1996; SEA Consultants, Inc., 1992, 2008; Sovereign Consulting, Inc., 2009; URS Corporation, 2003; and Bristol Engineering Advisors, Inc., 2011), USGS reports (Gay, 1981, 1985), and well construction reports kept at the USGS office in Northborough, Mass. Sedimentary logs and corresponding well construction records were available for 162 boreholes in the study area. These logs helped to establish details of the glacial sediment history and were used to define elevations and characteristics of hydrogeologic layers in the model.

\section{Geophysical Data}

Geophysical data were compiled from previous studies and were collected during this study (fig. 2) to establish depth to bedrock. Seismic data were collected between 1989 and 1994 by the MWRA as part of a study for construction of a water-supply tunnel that passes beneath the study area (GZA GeoEnvironmental, Inc., 1995). Depths to bedrock data were determined by seismic refraction methods along the seismic lines shown in figure 2 .

Passive seismic methods were used to measure depth to bedrock at 32 sites (fig. 2) where no borehole data were available and at 7 calibration sites where depths to bedrock were known. Passive seismic technology uses ambient ground vibrations caused by ocean waves, rainfall, wind, and anthropogenic activities to determine the thickness of unconsolidated sediments overlying bedrock (Ibs-von Seht and Wohlenberg, 1999; Lane and others, 2008). A three-component seismometer was used in this study to record the resonance frequency from ground vibrations, and a spectral analysis was made to obtain resonance frequencies related to the sediment thickness using equation 1.

$$
Z=a f_{r 0}^{b}
$$

where

$\begin{array}{cc}Z & \text { is the depth to bedrock at a location, in feet; } \\ f_{r 0} & \text { is the fundamental resonance frequency, in } \\ & \text { hertz; and } \\ a \text { and } b & \text { are constants determined by a nonlinear } \\ & \text { regression of data acquired at sites with } \\ \text { known depths to bedrock. }\end{array}$

Values for $a$ (359.29) and $b(-1.1979)$ were determined from the data collected at the seven control sites in the study area with known depths to bedrock (fig. 3A). The depths computed from equation 1 at the control sites generally better matched depths at higher resonance frequencies (shallower depths to bedrock) than at sites with lower resonance frequencies (deeper depths to bedrock). Depths to bedrock at the deeper control points in the study therefore were computed from calibrated coefficients $(a=297.24$ and $b=1.00)$ determined for Cape Cod (John Lane, U.S. Geological Survey, written commun., 2011), where depths to bedrock are generally deeper and more closely matched depths than those computed from locally derived coefficients. Depths to bedrock were therefore determined at sites with resonance frequencies greater than about 2.5 hertz (depths less than about $120 \mathrm{ft}$ ) from locally derived coefficients and resonance frequencies less than about 2.5 hertz (depths greater than $120 \mathrm{ft}$ ) from coefficients derived for Cape Cod (fig. 3B). Of the 32 passive seismic sites without known bedrock depths, 19 had depths greater than $120 \mathrm{ft}$, and 14 had depths less than $120 \mathrm{ft}$.

\section{Bedrock}

The study area is underlain by crystalline bedrock that crops out in places along the study area boundaries, predominantly on the east side, and at one location in the middle of the study area (fig. 4). To represent the bedrock surface as accurately as possible, the borehole and geophysical data described above were combined to produce a gridded bedrock surface elevation map. The bedrock elevation map was derived from compiled bedrock elevation data including (1) 120 boreholes, (2) 103 points from the MWRA seismic data profile lines, (3) 32 passive seismic points collected for this study, and (4) 2,383 control points. The control points were locations of bedrock outcrop and points from hand drawn contours of the deep bedrock valley by Janet R. Stone (U.S. Geological Survey, written commun., May 2011) identified to better constrain the automated interpolation of the bedrock surface. Some control points beyond the boundaries of the study area were used to improve surface interpolation at the edges of the study area where data were more sparse. The bedrock grid was set equal to the size of the groundwater model cells (50 square feet $\left(\mathrm{ft}^{2}\right)$ ) so that each grid value represented the elevation of the center of a model cell. 


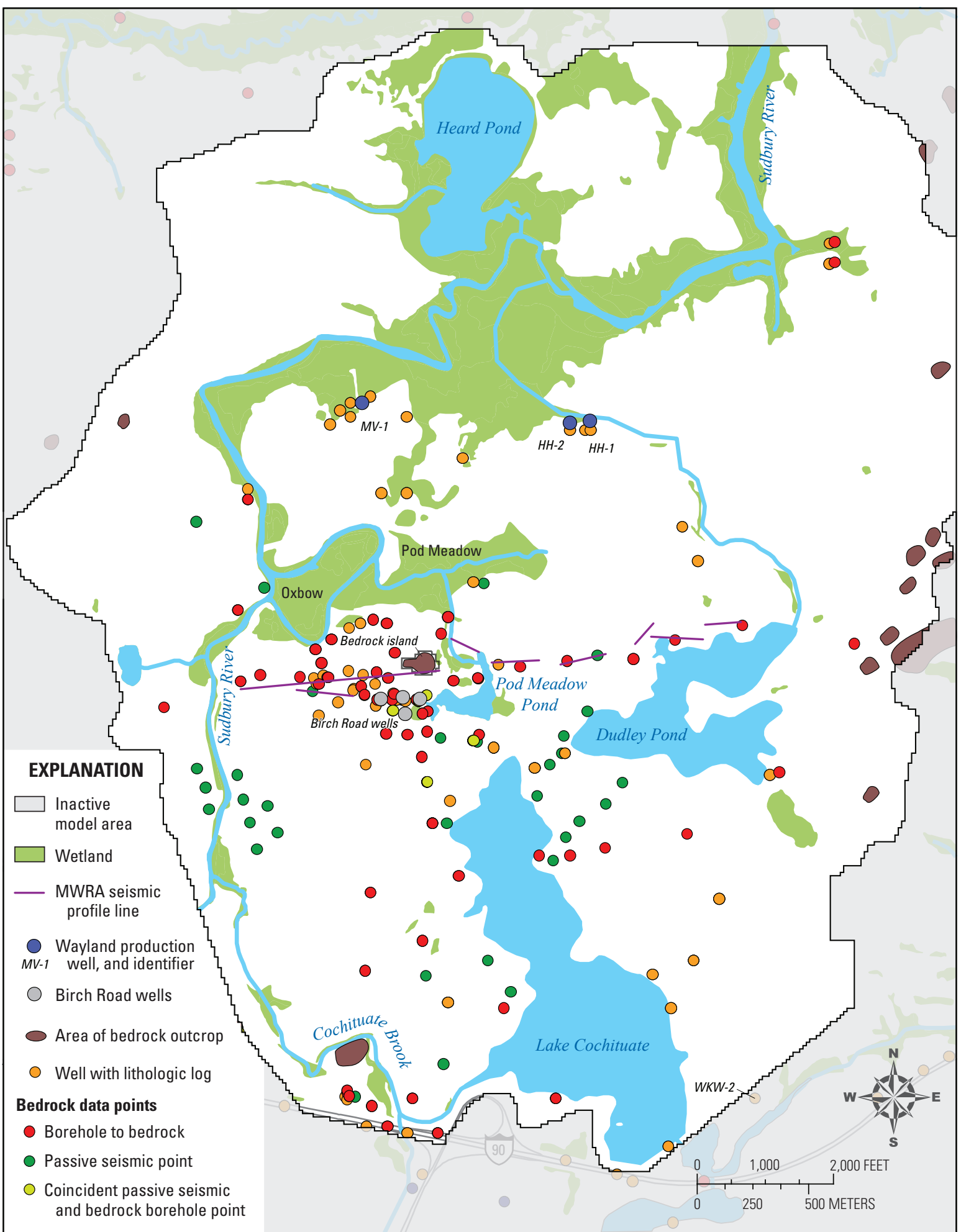

Base from U.S. Geological Survey and Massachusetts Geographic Information System data sources, Massachusetts State Plane Coordinate System, Mainland Zone

Figure 2. Well borings to bedrock, bedrock outcrops, passive seismic points, and seismic lines used to develop the hydrogeologic framework and bedrock surface topography, east central Massachusetts. 


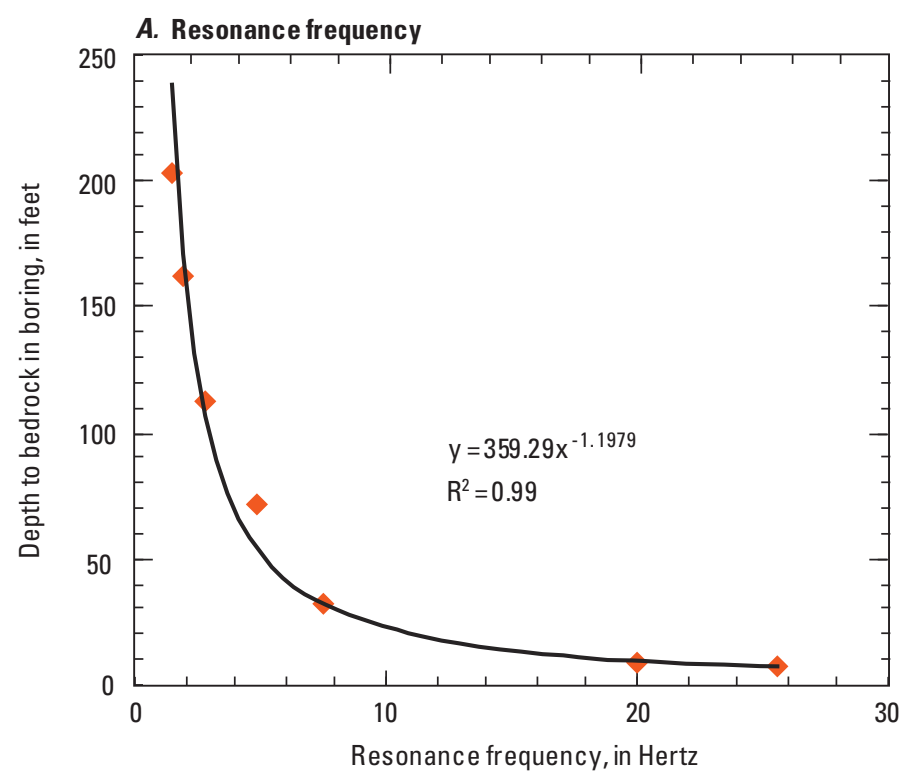

B. Estimated depth to bedrock

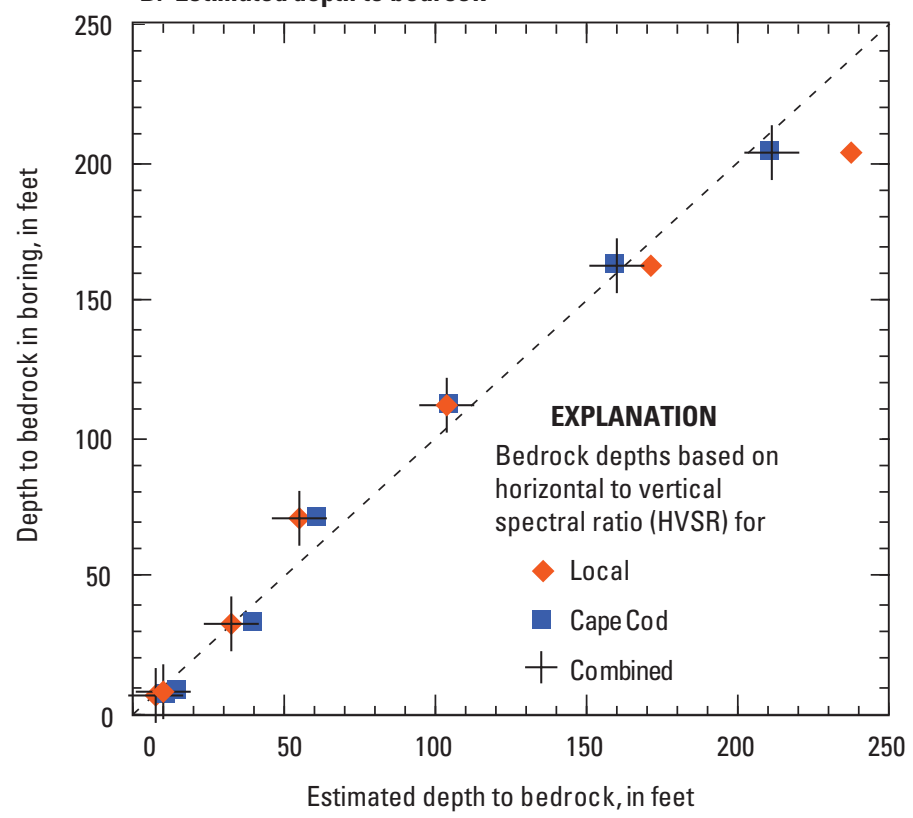

Figure 3. Passive seismic $A$, response resonance frequency at known bedrock depths and $B$, estimated and observed bedrock depths, east central Massachusetts.

Elevation of the bedrock surface is highly variable with a deep bedrock valley following the north-south axis of Lake Cochituate. Bedrock surface elevations range from outcrops at about $300 \mathrm{ft}$ on the east side of the study area to $-118 \mathrm{ft}$ at the bottom of the bedrock valley under Lake Cochituate (fig. 4). An isolated bedrock outcrop referred to as the "bedrock island" rises to an elevation of $165 \mathrm{ft}$ just north of the Birch Road wells and drops steeply eastward to an elevation of about $-40 \mathrm{ft}$. The bedrock valley generally continues to rise to the north of the bedrock island, but few data are available to confirm the bedrock topography in this area. Bedrock topography likely determines groundwater flow patterns in the study area because bedrock is much less permeable than the overlying glacial deposits.

Nelson (1974a, 1975) and Goldsmith (1991) present two somewhat different interpretations of bedrock lithology in the study area. Nelson $(1974 a, 1975)$ indicated that bedrock underlying the study area is composed of three units: (1) the Cherry Brook Formation west of Lake Cochituate and west and north of Dudley Pond, (2) the Westboro Quartzite east of Dudley Pond, and (3) the Dedham Granodiorite east of Lake Cochituate. Goldsmith (1991) presented bedrock as two units: (1) quartzite and (2) metavolcanic rocks overlapping somewhat with Nelson's units. All the bedrock is thought to be relatively impermeable, although the upper bedrock surface is considered more fractured and permeable because of weathering and glacial movement. The upper bedrock in other parts of Massachusetts has been shown to have an active groundwater flow system that serves as a source of water to wells (Boutt and others, 2010; Mabee and others, 2002; and Hanson and Simcox, 1994). Groundwater flow through the bedrock of the study area was documented during construction of a watersupply tunnel at depths of 200-500 ft below land surface. Groundwater flow rates were weakly correlated with observed lineaments (Mabee and others, 2002), and therefore lineaments were not represented in the model. In addition, groundwater levels in the glacial sediments and streamflow data do not indicate that the hydraulic properties of the bedrock affect shallow groundwater flow.

\section{Glacial Sediment History}

Overlying the bedrock in most of the study area are stratified glacial deposits laid down in the last stages of glacial Lake Charles during the retreat of the Wisconsin ice sheet (Clapp, 1904). A thin layer (generally 1-10 ft thick) of low-permeability glacial till lies immediately over bedrock in most areas. Thicker till deposits form several drumlin hills on the east and west sides of the study area (figs. 4, 5). Sediments blanket till and bedrock over most of the study area and are interpreted as glacial meltwater deltaic deposits (Stone and Stone, 2006), similar to those recognized and mapped in many places in New England (Koteff and Pessl, 1981). As the glacier retreated to the north and northwest, it periodically paused and deposited gravel and sand at its terminus. Three glacial sediment morphosequences (fig. 5), identified by areas of stratified sediments contained between landforms and ice margins, have been documented in the study area (Stone and Stone, 2006; Janet Stone, U.S. Geological Survey, written commun., 2011). Generally, meltwater sediment deposits were finer grained where they settled in glacial Lake Charles away from the ice margin and coarser grained where they settled near the ice margin or mouth of the meltwater streams. 


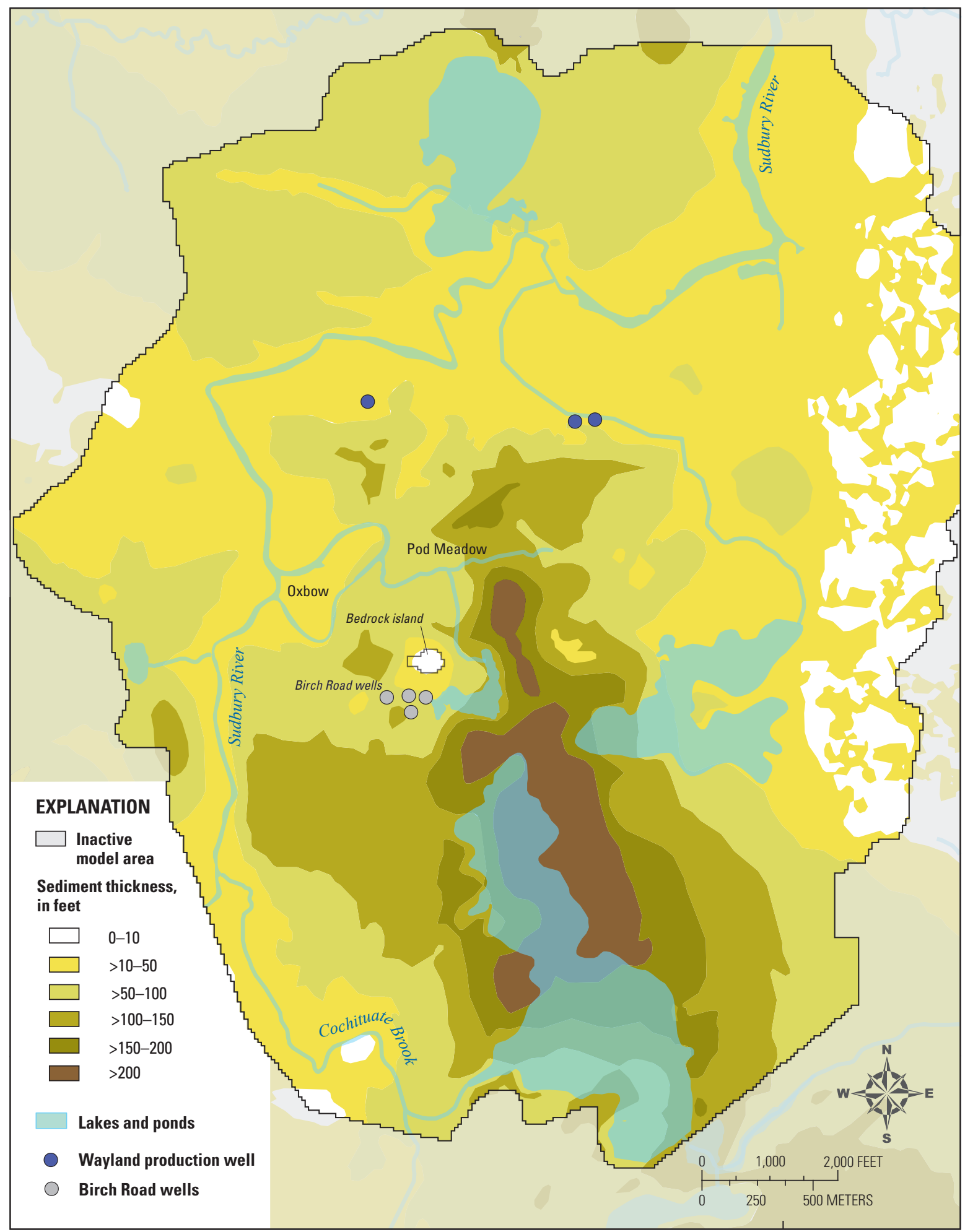

Base from U.S. Geological Survey and Massachusetts Geographic Information System data sources, Massachusetts State Plane Coordinate System, Mainland Zone

Figure 4. Thickness of sediments above the bedrock surface in the study area, east central Massachusetts. 


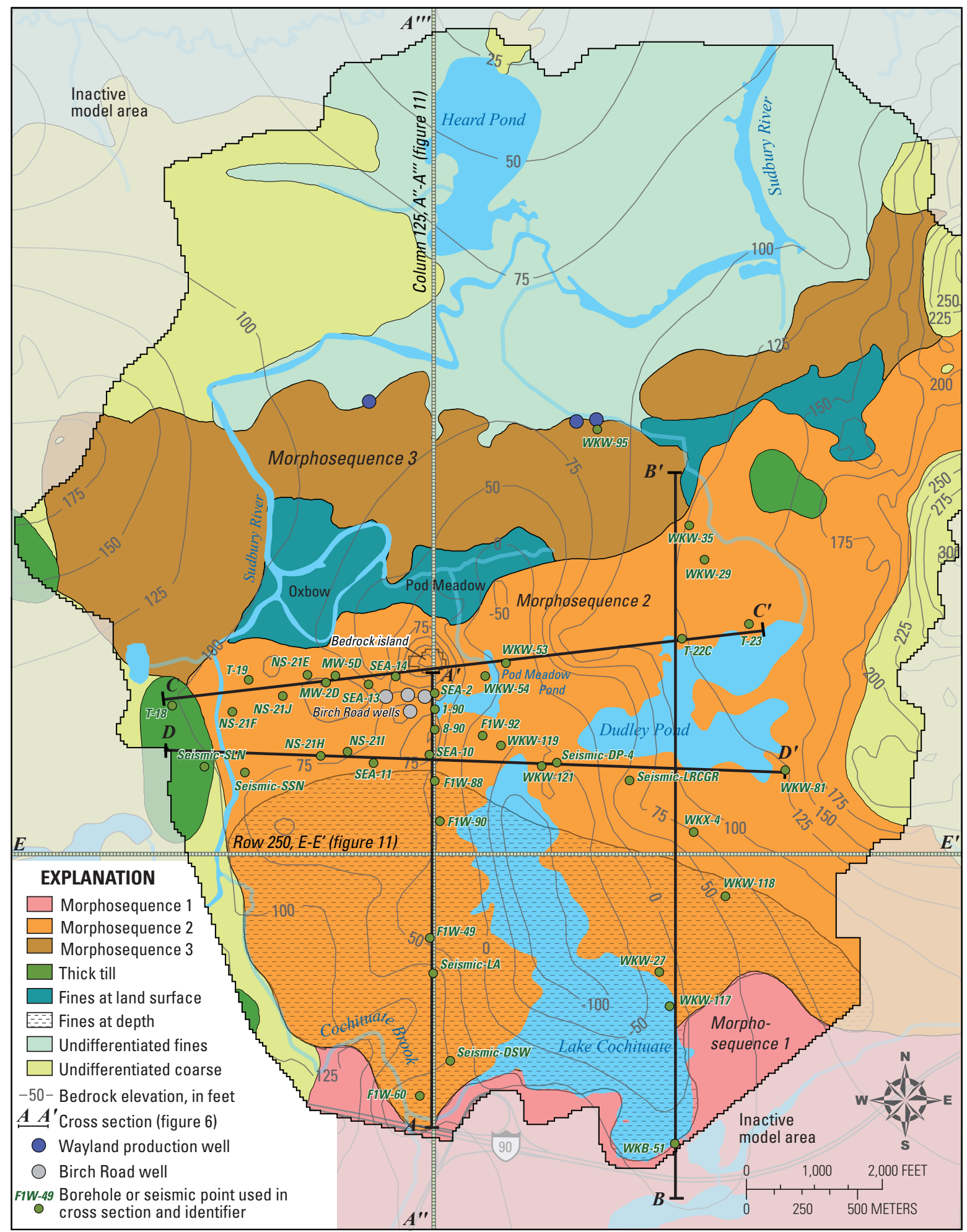

Base from U.S. Geological Survey and Massachusetts Geographic Information System data sources, Massachusetts State Plane Coordinate System, Mainland Zone

Modified from Stone and Stone, 2006 Bedrock elevation in NAVD 88

Figure 5. Locations of glacial-sediment deposits in the study area, east central Massachusetts. 
The sand and gravel deltaic deposits are interspersed with lower permeability fine-grained lacustrine deposits that are generally a mix of fine sands, silts, and clays (shown in light blue on fig. 5). Along geologic cross sections $\mathrm{A}-\mathrm{A}^{\prime}$ and $\mathrm{B}-\mathrm{B}^{\prime}$, extensive fine deposits are generally present below $140 \mathrm{ft}$ in elevation in the southernmost parts of the sections and are mostly overlain by more permeable coarse-grain deposits except where they underlie Lake Cochituate (fig. 6A). Extensive fine deposits also are found in the northern part of the study area to the north of cross-section lines A-A' and B-B'. Few borehole logs are available from this area to characterize these sediments, but those that do exist indicate that the fines consist of silty organic sediments, which may extend from the land surface to bedrock. The fine deposits in the middle part of the study area near the Birch Road wells are less extensive and slightly coarser (fine silts and silts) as indicated in crosssection lines $\mathrm{C}-\mathrm{C}^{\prime}$ and $\mathrm{D}-\mathrm{D}^{\prime}$ (fig. 6B). Contacts between sediments were determined from well logs and from a theoretical understanding of the morphosequences in which they were deposited. However, the positions of boundaries are highly variable and poorly known in most locations.

Beneath kettle depressions such as Dudley Pond, Lake Cochituate, and Pod Meadow Pond, the sediments collapsed as the ice blocks beneath them melted. The high water-surface elevation of Dudley Pond (153 ft) relative to the elevations of nearby Lake Cochituate (138.5 ft) and Pod Meadow Pond $(125.8 \mathrm{ft})$ is difficult to explain. Permeable sand and gravel deposits between the two sets of ponds should result in groundwater flow causing the level of Dudley Pond to drop closer to the level of Lake Cochituate. The reason these ponds can maintain such a high hydraulic gradient may lie at the bottom of the ponds. Sediment cores collected as part of an eutrophication study of Dudley Pond by the Town of Wayland (IEP, Inc., 1983) indicated a layer of bottom muck sediments up to $14 \mathrm{ft}$ thick. This muck layer, referred to as gyttja, is partially decayed organic material that settles out of the water column though time and has a black gel-like consistency. These deposits are an impediment to seepage losses from the pond to the aquifer and a likely explanation for why Dudley Pond exists and why the surface level does not substantially drop during the late summer when inflows to the pond are typically small. Similar deposits are believed to underlie parts of northern Lake Cochituate (dark blue in sections B- $\mathrm{B}^{\prime}, \mathrm{C}-\mathrm{C}^{\prime}$, and $\mathrm{D}-\mathrm{D}^{\prime}$, figs. $6 \mathrm{~A}$ and $\mathrm{B}$ ) as evidenced by up to $12 \mathrm{ft}$ of gyttja deposits determined from ground-penetrating radar surveys of the South Pond of Lake Cochituate (Friesz and Church, 2001).

\section{Water Resources}

Surface water generally is in hydraulic connection with groundwater in the study area. Both surface water and groundwater are supplied by abundant precipitation, with average annual precipitation in 2004-09 measuring about 50 inches (in) at nearby Natick, Mass. (National Oceanic and Atmospheric Administration (NOAA) station USC00195175).

\section{Surface-Water Features}

The major surface-water features in the study area include the Sudbury River to the west and north, the northernmost pond of Lake Cochituate to the south, Cochituate Brook to the southwest, Dudley Pond to the east, and Pod Meadow Pond (fig. 7). The shallow and permeable aquifer system is generally in close hydraulic connection with the abundant surface-water features in the study area, but the connection may be locally constrained by gyttja deposits in lakes and ponds as previously described.

Lake Cochituate consists of four ponds (only the northernmost is shown in fig. 7) connected by shallow, narrow waterways that form a relatively long south-north trending lake. Total drainage area at the lake outlet is $17.5 \mathrm{mi}^{2}$. The lake is a series of kettle ponds formed following the last glacial retreat. Of these four connected ponds, only the northernmost pond - hereafter called "Lake Cochituate"-is in the study area. This part of the lake has a $0.31 \mathrm{mi}^{2}$ surface area and drains to the westward-flowing Cochituate Brook that connects to the northeastward-flowing Sudbury River. Streamflow in Cochituate Brook (fig. 7) was monitored by the USGS (01098500) from October 1977 to June 1979 and from August 2010 through June 2012. Daily mean flow for this entire period was $34.9 \mathrm{ft}^{3} / \mathrm{s}$. Lake Cochituate stage has been continuously monitored by the USGS (01098499) since August 2010, during which time the lake level varied by $2.1 \mathrm{ft}$ through December 2011 and was lowest during parts of the summer when levels dropped below the crest of the outlet spillway. Flow and stage data collected by the USGS are maintained in the National Water Information System (NWIS), which is available at http://waterdata.usgs.gov/nwis.

Other ponds in the study area include Dudley Pond northeast of Lake Cochituate, Pod Meadow Pond north of Lake Cochituate, and Heard Pond in the north-central part of the study area (fig. 7). Heard Pond was not explicitly modeled because of its distance from the Birch Road wells and location on the opposite side of the Sudbury River. Dudley Pond, also a kettle pond, has a surface area of $0.14 \mathrm{mi}^{2}$ and a total drainage area of $0.58 \mathrm{mi}^{2}$ measured at its outlet. Pod Meadow Pond has a surface area of $0.01 \mathrm{mi}^{2}$ and a drainage area of $0.23 \mathrm{mi}^{2}$. Early topographic maps show Pod Meadow Pond as a wetland that was likely modified by sand and gravel excavations in the early to mid-20th century.

Outflows from Pod Meadow Pond and Dudley Pond (fig. 7) were measured monthly starting in March 2011 to provide data for groundwater model calibration. The quality of streamflow measurement data was generally considered good to fair, but was poor (as defined by Kennedy, 1983) at the lowest flows because of low stream depth and velocity. Drainage areas at the outflow measurement sites to Pod Meadow Pond and Dudley Pond are 0.23 and $0.58 \mathrm{mi}^{2}$, respectively; however, discharge measurements (table 1) averaged nearly the same at the two sites except for the November 2011 measurements at Pod Meadow Pond outlet, which were affected by a beaver dam that caused water to 

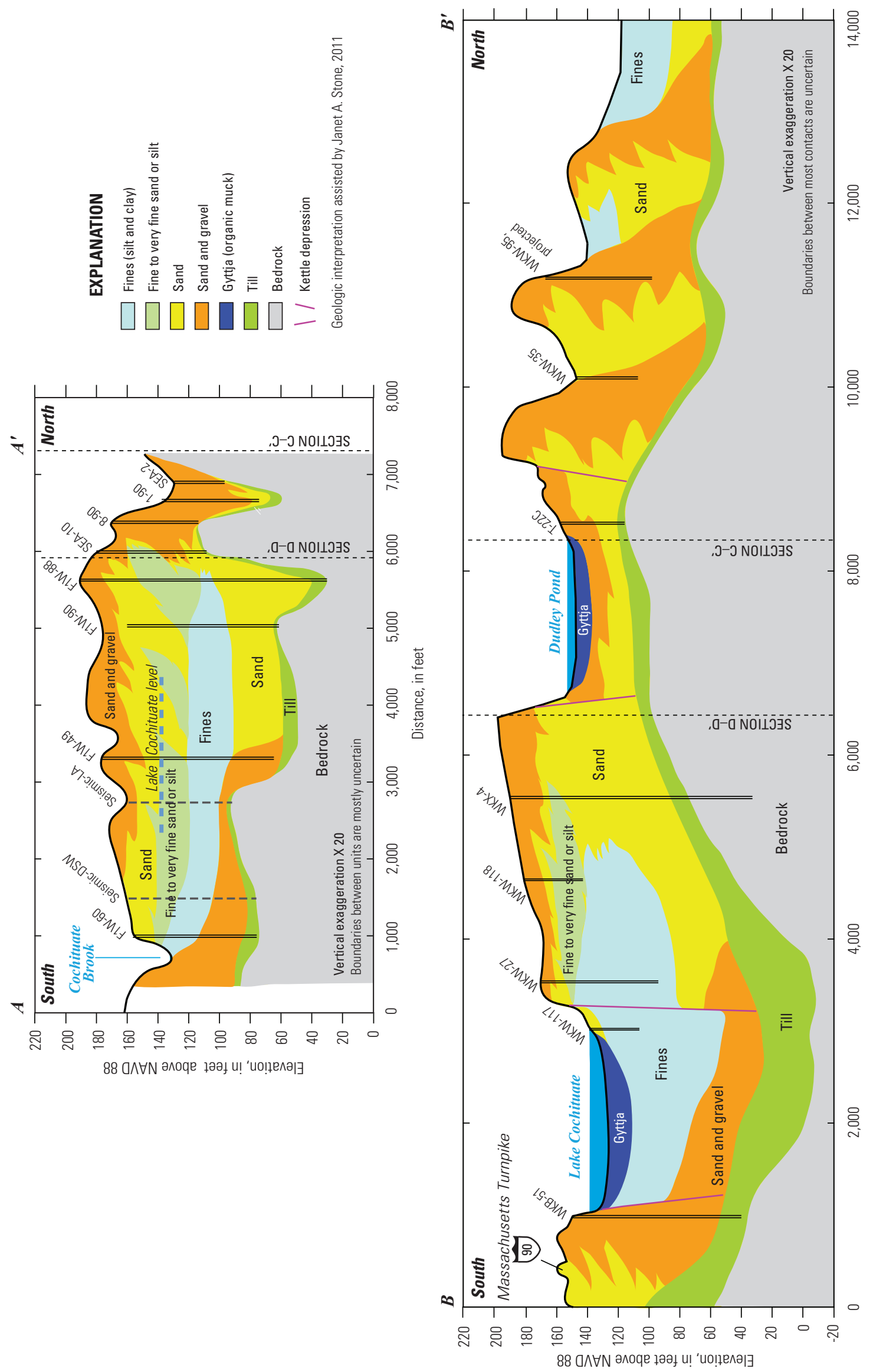

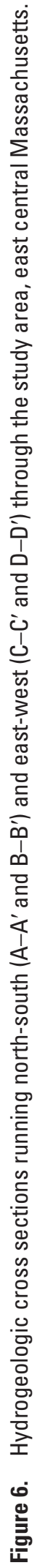



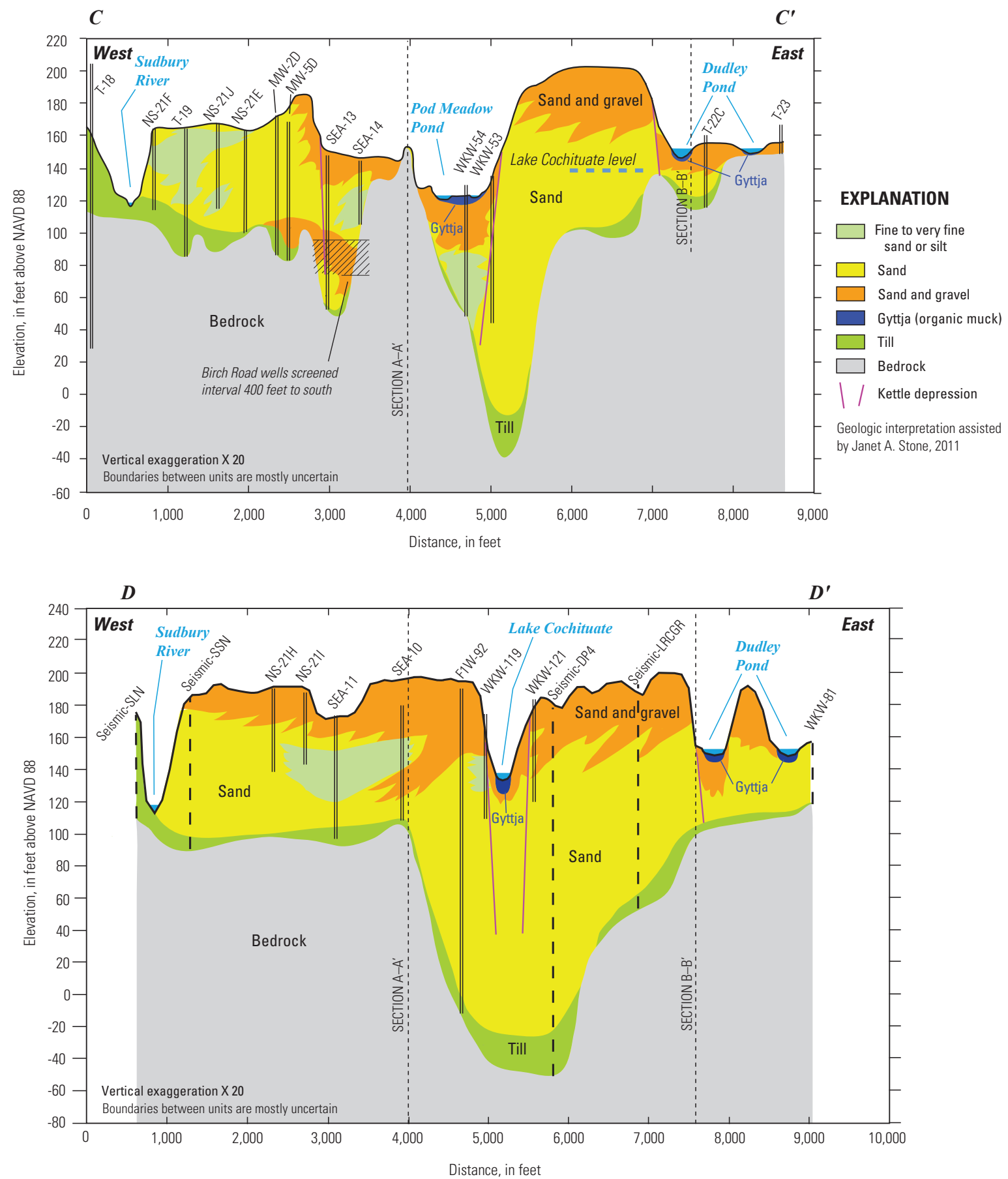

Figure 6. Hydrogeologic cross sections running north-south $\left(A-A^{\prime}\right.$ and $\left.B-B^{\prime}\right)$ and east-west $\left(C-C^{\prime}\right.$ and $\left.D-D^{\prime}\right)$ through the study area, east central Massachusetts. - Continued 


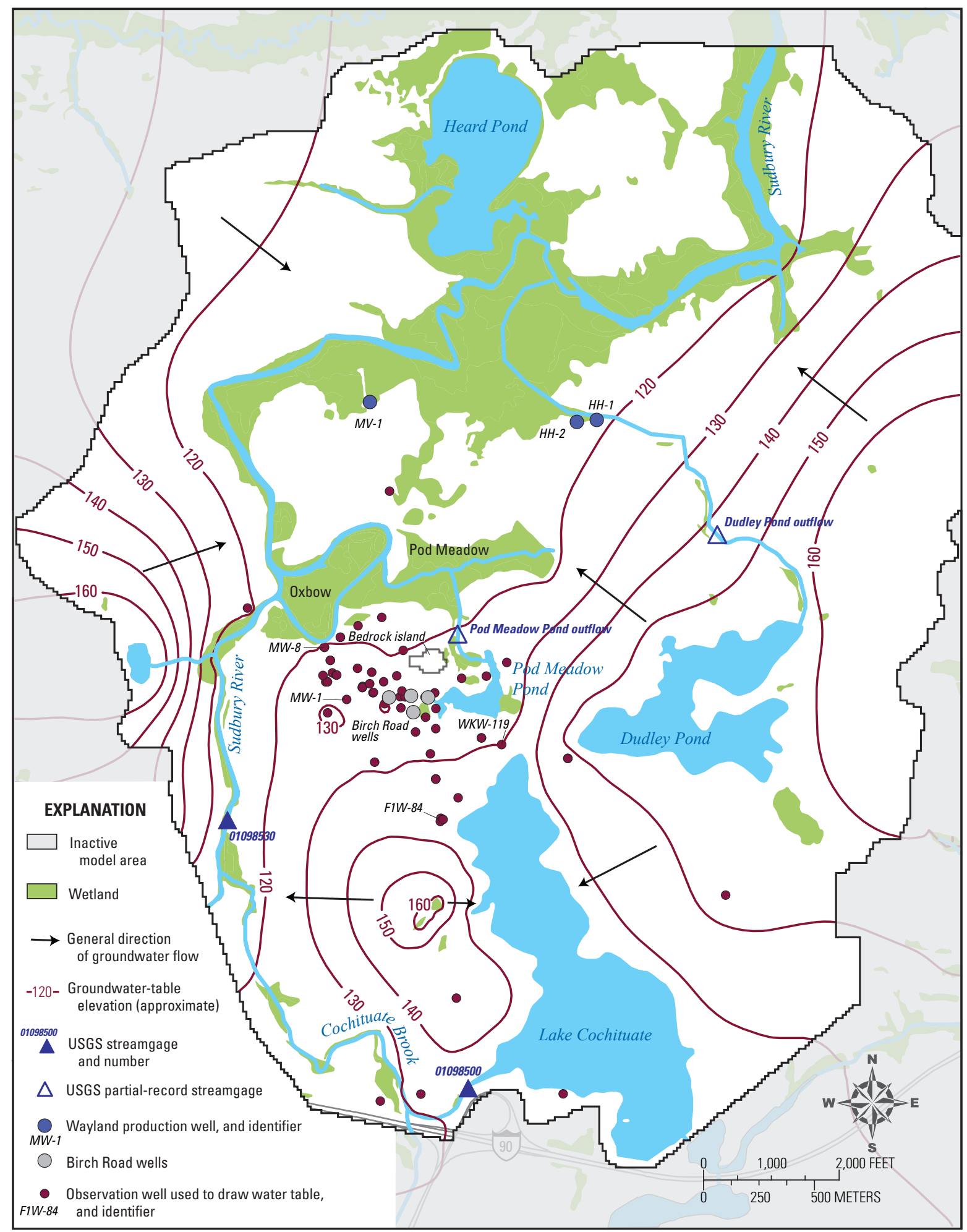

Base from U.S. Geological Survey and Massachusetts Geographic Information System data sources, Massachusetts State Plane Coordinate System, Mainland Zone

Figure 7. Surface-water features and interpolated groundwater table elevations in the study area, east central Massachusetts. 
Table 1. Discharge measurements at the outflows from Pod Meadow Pond and Dudley Pond, east central Massachusetts.

\begin{tabular}{|c|c|c|}
\hline \multirow[t]{2}{*}{ Date } & \multicolumn{2}{|c|}{$\begin{array}{c}\text { Discharge } \\
\text { (cubic feet per second) }\end{array}$} \\
\hline & Pod Meadow Pond & Dudley Pond \\
\hline $03-23-2011$ & 1.18 & 1.71 \\
\hline 05-09-2011 & 0.79 & 1.21 \\
\hline 06-14-2011 & 0.65 & 0.52 \\
\hline $07-12-2011$ & 0.43 & 0.08 \\
\hline 08-01-2011 & 0.54 & 0.00 \\
\hline 09-12-2011 & 0.74 & 0.61 \\
\hline $10-07-2011$ & 0.45 & 0.53 \\
\hline $11-10-2011$ & $0.14^{1}$ & $0.91^{2}$ \\
\hline $11-29-2011$ & $0.12^{1}$ & 0.79 \\
\hline $12-14-2011$ & 0.58 & 1.03 \\
\hline 01-09-2012 & 0.86 & 1.30 \\
\hline 02-08-2012 & 0.68 & 0.92 \\
\hline 03-08-2012 & 0.75 & 0.75 \\
\hline Mean & 0.70 & 0.79 \\
\hline Standard deviation & 0.21 & 0.52 \\
\hline
\end{tabular}

${ }^{1}$ Discharge affected by beaver dam that was impounding water; values excluded from mean and standard deviation.

${ }^{2}$ Measurement made on 11-08-2011.

pool upstream of the measurement site. Discharge from Pod Meadow Pond also was relatively consistent, ranging from 0.43 to $1.18 \mathrm{ft}^{3} / \mathrm{s}$, compared to the outflow from Dudley Pond, which ranged from 0 to $1.71 \mathrm{ft}^{3} / \mathrm{s}$. The relatively high and consistent outflow from Pod Meadow Pond, which has a small contributing area relative to Dudley Pond, suggests a larger groundwater discharge to Pod Meadow Pond than to Dudley Pond. This higher outflow is also evident from anecdotal reports that the southwestern part of Pod Meadow Pond does not freeze, which was confirmed during site visits in the winter of 2010-11 (fig. 8) when both Lake Cochituate and Dudley Pond were completely frozen and part of Pod Meadow Pond was not, indicating discharge of relatively warm groundwater. Factors that could contribute to the groundwater discharge at Pod Meadow Pond include its low topographic position, removal of surface material and lowered topography as a result of past mining activities, occurrence of high permeability sand and gravel, proximity to Lake Cochituate and related steep hydraulic gradient to the lake, increasing bedrock elevation forcing groundwater flow upward, and the pond's position just north of the edge of the extensive layer of low-permeability fine-grained sediments.

Extensive wetlands exist adjacent to the Sudbury River and other streams in the northern part of the study area. Pod
Meadow Pond drains north into the Pod Meadow wetland, which then drains into the oxbow on the Sudbury River. Just north of the oxbow, the Sudbury River meanders through extensive wetlands that are part of the Great Meadows National Wildlife Refuge (fig. 1).

The Sudbury River flows from the southwest toward the northeast through the study area and is the primary drainage feature that likely receives all groundwater discharge from the study area aquifer, either directly or indirectly from numerous tributaries. The drainage area of the Sudbury River is about $85 \mathrm{mi}^{2}$ at its entrance to the study area and about $111 \mathrm{mi}^{2}$ at its exit from the study area. Groundwater levels indicate that there is little or no groundwater crossing beneath the river. Flow in the Sudbury River near the southwestern boundary of the study area has been continuously monitored at Saxonville (01098530) since October 1979. Mean daily flow at Saxonville from October 1979 through September 2009 was $205 \mathrm{ft}^{3} / \mathrm{s}$ with monthly mean flows ranging from $71 \mathrm{ft}^{3} / \mathrm{s}$ in September to $384 \mathrm{ft}^{3} / \mathrm{s}$ in April.

\section{Groundwater Levels and Flow Paths}

Groundwater level measurements collected in and near the study area for a variety of purposes were compiled for this study. Groundwater levels were obtained from NWIS or compiled from previous site investigations (Balsam, 1987, 1992; SEA, 1992, 2008). Additional groundwater observations were also made during this study (Peter Newton, Bristol Engineering Advisors, Inc., written commun., 2011). The complete set of groundwater level observations (table 2) spans the period from 1931 through 2011. Water levels from individual observation wells span shorter periods, were obtained over a wide range of hydroclimatic conditions, and may not represent the long-term average.

Water levels from observation wells and surface elevations of water bodies were used to develop a water-table map (fig. 7), which was manually interpolated and contoured. The water-table map indicates that regional groundwater flow is towards the Sudbury River. Groundwater discharges to the eastern boundary of Lake Cochituate from both the deep and shallow aquifer, but along the western lake boundary, groundwater flow in the shallow aquifer is towards the lake while groundwater flow in the deeper aquifer is away from the lake towards the Sudbury River. To the west of Lake Cochituate, water levels in shallow wells have been measured as much as $20 \mathrm{ft}$ higher than water levels in deep wells. The lowpermeability lacustrine deposits in this area may cause locally perched water table conditions, hydraulically separating the upper and lower parts of the aquifer (fig. 6A). Groundwater levels from vertically paired wells in other parts of the study area (not shown in fig. 7) indicate little difference between shallow and deep parts of the aquifer, indicating that the aquifer is unconfined, and that deep and shallow levels of the aquifer are probably hydraulically well connected. 


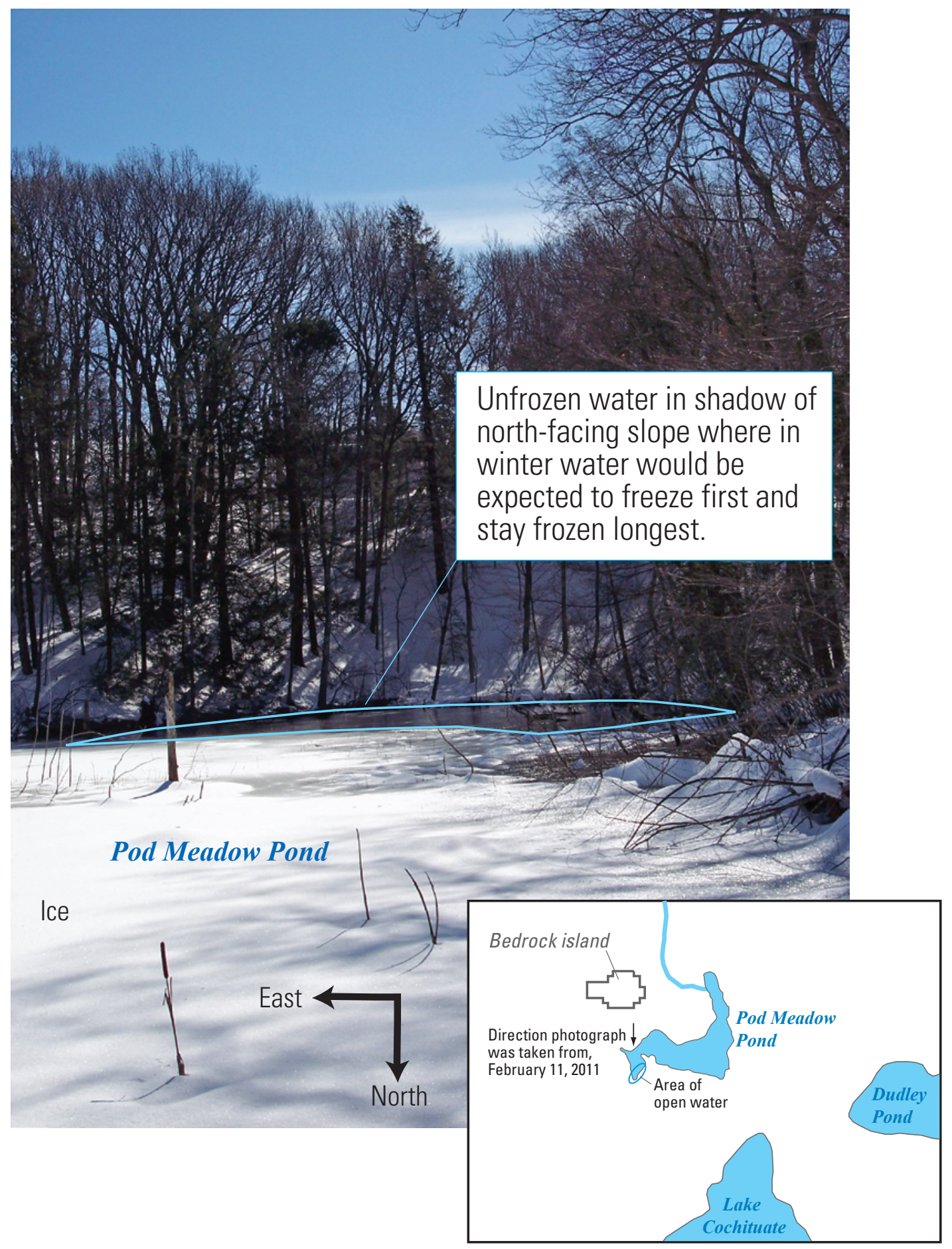

Figure 8. Pod Meadow Pond showing open water along the southern shore in February 2011, Framingham, Massachusetts. 
Table 2. Borehole and groundwater observation wells used in the study, east central Massachusetts.

[Well locations shown in figures 7 and 15; Elevation in North American Vertical Datum 1988; SS, used to calibrate steady-state model; TR, used to calibrate transient model; LI, used to determine lithology; WL, water level(s) used to develop model; WS, water-supply well; --, no data available. Data sources are: 1, SEA Consultants, Inc. (1992); 2, SEA Consultants, Inc., (2008); 3, Gay (1985); 4, Gay (1981); 5, Balsam (1987, volume I); 6, Balsam (1987, volume II); 7, Balsam (1992, volume I); 8, Balsam (1992, volume II); 9, Sovereign Consulting, Inc. (2009); 11, U.S. Geological Survey files in Northborough, Mass. (accessed 2011); 13, National Water Information System (NWIS) online at http://waterdata.usgs.gov/nwis; 15, Wayland Wellhead Protection Committee and Bruce W. Young (2011)]

\begin{tabular}{|c|c|c|c|c|c|c|c|c|c|c|c|c|}
\hline \multirow{2}{*}{$\begin{array}{l}\text { Well } \\
\text { identifier }\end{array}$} & \multirow{2}{*}{$\begin{array}{l}\text { Data } \\
\text { source }\end{array}$} & \multirow[t]{2}{*}{ Longitude } & \multirow[t]{2}{*}{ Latitude } & \multirow{2}{*}{$\begin{array}{l}\text { Land } \\
\text { surface } \\
\text { elevation } \\
\text { (feet) }\end{array}$} & \multirow{2}{*}{$\begin{array}{l}\text { Hole } \\
\text { depth } \\
\text { (feet) }\end{array}$} & \multirow{2}{*}{$\begin{array}{c}\text { Bedrock } \\
\text { eleva- } \\
\text { tion } \\
\text { (feet) }\end{array}$} & \multicolumn{2}{|c|}{$\begin{array}{l}\text { Screen elevation } \\
\text { (feet) }\end{array}$} & \multirow{2}{*}{$\begin{array}{c}\text { Screen } \\
\text { model } \\
\text { layer }\end{array}$} & \multicolumn{3}{|c|}{$\begin{array}{l}\text { Water-level observations } \\
\text { (feet) }\end{array}$} \\
\hline & & & & & & & Top & Bottom & & Count & Average & Application \\
\hline $1-90$ & 1 & -71.3858 & 42.3301 & 136.0 & 63.0 & -- & 83.0 & 78.0 & 4 & 1 & 125.4 & SS, LI \\
\hline $2-90$ & 1 & -71.3864 & 42.3305 & 135.5 & 79.0 & 56.5 & 82.5 & 77.5 & 4 & 1 & 125.5 & SS, LI \\
\hline $3-90$ & 1 & -71.3872 & 42.3306 & 145.1 & 74.0 & -- & 94.1 & 89.1 & 4 & 4 & 127.3 & SS, LI \\
\hline $5-90$ & 1 & -71.3878 & 42.3306 & 131.9 & 76.0 & 55.9 & 78.9 & 73.9 & 4 & 4 & 127.7 & SS, LI \\
\hline $7-90$ & 1 & -71.3876 & 42.3324 & 145.6 & 48.0 & 97.6 & 102.7 & 97.7 & 4 & 4 & 120.0 & SS, TR, LI \\
\hline $8-90$ & 1 & -71.3858 & 42.3293 & 172.3 & 56.0 & 116.3 & 88.3 & 83.3 & 4 & 4 & 127.2 & SS, LI \\
\hline F1W-41 & 3 & -71.3864 & 42.3297 & 135.0 & 61.1 & -- & 90.0 & 72.0 & 4 & 1 & 128.9 & SS, MD \\
\hline F1W-42 & 3 & -71.3875 & 42.3306 & 142.0 & 62.3 & -- & 76.6 & 61.6 & 4 & 1 & 128.2 & $\mathrm{SS}, \mathrm{MD}$ \\
\hline F1W-43 & 3 & -71.3886 & 42.3303 & 135.0 & 60.2 & 76.0 & 89.3 & 71.3 & 4 & 1 & 130.9 & $\mathrm{SS}, \mathrm{MD}$ \\
\hline F1W-60 & 4 & -71.3867 & 42.3144 & 138.0 & 80.1 & 57.8 & 62.8 & 57.8 & 4 & 1 & 137.3 & SS, LI \\
\hline F1W-64 & 11 & -71.3961 & 42.3342 & 125.0 & 23.8 & 101.2 & 125.0 & 120.0 & 1 & 1 & 122.1 & SS, LI \\
\hline F1W-74 & 5 & -71.3789 & 42.3144 & 140.0 & 71.0 & 69.0 & 95.0 & 90.0 & 4 & 1 & 138.2 & SS, LI \\
\hline F1W-84 & 3 & -71.3856 & 42.3256 & 139.5 & 18.0 & -- & 127.5 & 124.5 & 2 & 16 & 137.5 & SS, TR \\
\hline F1W-85 & 3 & -71.3847 & 42.3183 & 173.0 & 37.0 & -- & 149.0 & 146.0 & 2 & 19 & 149.9 & WL, LI \\
\hline F1W-87 & 3 & -71.3858 & 42.3272 & 193.4 & 65.0 & -- & 134.4 & 131.4 & 2 & 49 & 149.6 & WL \\
\hline F1W-88 & 3 & -71.3858 & 42.3272 & 193.3 & 163.0 & 30.3 & 104.8 & 101.8 & 4 & 11 & 127.6 & SS, LI \\
\hline F1W-89 & 3 & -71.3858 & 42.3272 & 193.3 & 163.0 & 30.3 & 55.6 & 52.6 & 4 & 8 & 127.6 & SS, TR, LI \\
\hline F1W-90 & 3 & -71.3856 & 42.3256 & 142.7 & 101.0 & 45.7 & 71.7 & 68.7 & 4 & 8 & 133.1 & SS, LI \\
\hline F1W-91 & 3 & -71.3856 & 42.3256 & 142.8 & 101.0 & 45.8 & 47.8 & 44.8 & 4 & 8 & 134.0 & SS, TR, LI \\
\hline F1W-92 & 13 & -71.3889 & 42.3142 & 191.2 & 203.0 & -11.8 & 120.0 & 117.0 & 2 & 9 & 127.2 & SS, TR, LI \\
\hline F1W-93 & 13 & -71.3833 & 42.3289 & 191.2 & 203.0 & -- & 73.3 & 70.3 & 4 & 10 & 127.2 & SS, TR \\
\hline F1W-94 & 4 & -71.3833 & 42.3289 & 191.2 & 203.0 & -11.8 & 20.5 & 17.5 & 4 & 9 & 127.1 & SS, LI \\
\hline HH-1 & 15 & -- & -- & 125.9 & 42.0 & -- & -- & -- & 4 & -- & -- & WS \\
\hline HН-2 & 15 & -- & -- & 125.7 & 47.0 & -- & -- & -- & 4 & -- & -- & WS \\
\hline MV-1 & 15 & -- & -- & 124.5 & 80.0 & -- & -- & -- & 4 & -- & -- & WS \\
\hline MW-1 & 6 & -71.3907 & 42.3305 & 176.5 & 60.5 & -- & 128.5 & 118.5 & 4 & 12 & 127.1 & SS, TR, LI \\
\hline MW-10 & 6 & -71.3916 & 42.3320 & 162.4 & 49.0 & -- & 124.4 & 114.4 & 2 & 11 & 121.1 & SS, LI \\
\hline MW-11 & 6 & -71.3916 & 42.3320 & 162.9 & 81.5 & 81.4 & 89.9 & 84.9 & 4 & 12 & 124.6 & SS, LI \\
\hline MW-12 & 6 & -71.3901 & 42.3334 & 123.1 & 16.5 & -- & 119.1 & 109.1 & $1-2$ & 9 & 118.3 & SS, LI \\
\hline MW-13 & 6 & -71.3898 & 42.3310 & 171.6 & 54.0 & -- & 129.6 & 119.6 & $3-4$ & 7 & 127.6 & SS, TR, LI \\
\hline MW-14 & 6 & -71.3898 & 42.3309 & 171.4 & 60.0 & -- & 121.4 & 111.4 & 4 & 4 & 127.8 & SS, LI \\
\hline MW-14R & 6 & -71.3898 & 42.3309 & 171.4 & 60.0 & -- & 121.4 & 111.4 & 4 & 2 & 126.9 & SS, LI \\
\hline MW-15 & 8 & -71.3893 & 42.3307 & 143.0 & 20.0 & -- & 133.0 & 123.0 & 2 & 2 & 127.0 & SS, LI \\
\hline MW-15D & 8 & -71.3892 & 42.3307 & 143.0 & 87.0 & -- & 75.0 & 65.0 & 4 & 2 & 127.3 & SS, LI \\
\hline MW-16 & 8 & -71.3887 & 42.3312 & 142.8 & 26.5 & -- & 137.8 & 117.8 & 2 & 2 & 130.2 & SS, LI \\
\hline MW-2 & 6 & -71.3918 & 42.3312 & 172.6 & 55.5 & -- & 127.6 & 117.6 & 4 & 12 & 126.5 & SS, LI \\
\hline MW-2B & 6 & -71.3918 & 42.3312 & 172.7 & 55.0 & -- & 129.7 & 119.7 & $3-4$ & 11 & 126.9 & SS, LI \\
\hline MW-2D & 6 & -71.3917 & 42.3312 & 172.4 & 86.5 & 85.9 & 110.4 & 100.4 & 4 & 6 & 126.1 & SS, LI \\
\hline MW-3 & 6 & -71.3920 & 42.3314 & 169.3 & 55.5 & -- & 125.3 & 115.3 & 4 & 12 & 128.2 & SS, TR, LI \\
\hline MW-4 & 6 & -71.3915 & 42.3315 & 167.0 & 45.5 & -- & 133.0 & 123.0 & $3-4$ & 12 & 124.4 & SS, LI \\
\hline
\end{tabular}


Table 2. Borehole and groundwater observation wells used in the study, east central Massachusetts.—Continued

[Well locations shown in figures 7 and 15; Elevation in North American Vertical Datum 1988; SS, used to calibrate steady-state model; TR, used to calibrate transient model; LI, used to determine lithology; WL, water level(s) used to develop model; WS, water-supply well; --, no data available. Data sources are: 1, SEA Consultants, Inc. (1992); 2, SEA Consultants, Inc., (2008); 3, Gay (1985); 4, Gay (1981); 5, Balsam (1987, volume I); 6, Balsam (1987, volume II); 7, Balsam (1992, volume I); 8, Balsam (1992, volume II); 9, Sovereign Consulting, Inc. (2009); 11, U.S. Geological Survey files in Northborough, Mass. (accessed 2011); 13, National Water Information System (NWIS) online at http://waterdata.usgs.gov/nwis; 15, Wayland Wellhead Protection Committee and Bruce W. Young (2011)]

\begin{tabular}{|c|c|c|c|c|c|c|c|c|c|c|c|c|}
\hline \multirow{2}{*}{$\begin{array}{l}\text { Well } \\
\text { identifier }\end{array}$} & \multirow{2}{*}{$\begin{array}{c}\text { Data } \\
\text { source }\end{array}$} & \multirow[t]{2}{*}{ Longitude } & \multirow[t]{2}{*}{ Latitude } & \multirow{2}{*}{$\begin{array}{l}\text { Land } \\
\text { surface } \\
\text { elevation } \\
\text { (feet) }\end{array}$} & \multirow{2}{*}{$\begin{array}{l}\text { Hole } \\
\text { depth } \\
\text { (feet) }\end{array}$} & \multirow{2}{*}{$\begin{array}{c}\text { Bedrock } \\
\text { eleva- } \\
\text { tion } \\
\text { (feet) }\end{array}$} & \multicolumn{2}{|c|}{$\begin{array}{l}\text { Screen elevation } \\
\text { (feet) }\end{array}$} & \multirow{2}{*}{$\begin{array}{c}\text { Screen } \\
\text { model } \\
\text { layer }\end{array}$} & \multicolumn{3}{|c|}{$\begin{array}{l}\text { Water-level observations } \\
\text { (feet) }\end{array}$} \\
\hline & & & & & & & Top & Bottom & & Count & Average & Application \\
\hline MW-5 & 6 & -71.3913 & 42.3315 & 169.4 & 55.5 & -- & 125.4 & 115.4 & 4 & 12 & 125.7 & SS, LI \\
\hline MW-5D & 8 & -71.3912 & 42.3314 & 169.4 & 89.0 & 82.9 & 101.4 & 91.4 & 4 & 2 & 126.2 & SS, LI \\
\hline MW-6 & 6 & -71.3917 & 42.3299 & 176.3 & 55.5 & -- & 132.3 & 122.3 & 4 & 2 & 131.9 & SS, LI \\
\hline MW-7 & 6 & -71.3901 & 42.3317 & 173.1 & 60.5 & -- & 124.1 & 114.1 & $3-4$ & 11 & 131.0 & SS, LI \\
\hline MW-8 & 6 & -71.3919 & 42.3326 & 129.7 & 19.0 & -- & 121.7 & 111.7 & $1-2$ & 12 & 120.6 & SS, TR, LI \\
\hline MW-8D & 6 & -71.3919 & 42.3326 & 129.6 & 56.0 & 73.6 & 84.6 & 74.6 & 4 & 6 & 121.7 & SS, TR, LI \\
\hline MW-9 & 6 & -71.3910 & 42.3330 & 125.3 & 18.5 & -- & 121.3 & 111.3 & $1-2$ & 12 & 117.9 & SS, LI \\
\hline MW-9D & 6 & -71.3910 & 42.3330 & 125.5 & 62.5 & 65.0 & 77.5 & 67.5 & 4 & 4 & 119.8 & SS, LI \\
\hline SEA-10 & 2 & -71.3861 & 42.3282 & 180.6 & 72.0 & 108.6 & 114.6 & 109.6 & 4 & 3 & 127.9 & SS, TR, LI \\
\hline SEA-11 & 2 & -71.3892 & 42.3279 & 174.2 & 77.0 & -- & 102.2 & 97.2 & 4 & 3 & 129.6 & SS, TR, LI \\
\hline SEA-12 & 2 & -71.3893 & 42.3316 & 161.2 & 85.0 & -- & 81.2 & 76.2 & 4 & 3 & 121.8 & SS, LI \\
\hline SEA-13 & 2 & -71.3894 & 42.3311 & 155.6 & 95.5 & 60.1 & 93.6 & 88.6 & 4 & 3 & 127.8 & SS, LI \\
\hline SEA-14 & 2 & -71.3880 & 42.3314 & 144.8 & 39.5 & 105.3 & 110.3 & 105.3 & 4 & 3 & 121.9 & SS, LI \\
\hline SEA-15 & 2 & -71.3888 & 42.3338 & 122.0 & 98.0 & -- & 58.0 & 53.0 & 4 & 3 & 117.6 & SS, TR, LI \\
\hline SEA-16 & 2 & -71.3846 & 42.3265 & 186.2 & 123.5 & -- & 94.2 & 89.2 & 4 & 3 & 131.7 & SS, LI \\
\hline SEA-17 & 2 & -71.3884 & 42.3305 & 139.0 & 60.0 & -- & 84.0 & 79.0 & 4 & 3 & 127.8 & SS, LI \\
\hline SEA-18 & 2 & -71.3869 & 42.3291 & 149.0 & 59.0 & 90.0 & 95.0 & 90.0 & 4 & 3 & 127.7 & SS, LI \\
\hline SEA-2 & 2 & -71.3859 & 42.3307 & 128.7 & 32.5 & -- & 101.2 & 96.2 & 4 & 3 & 125.6 & SS, LI \\
\hline SEA-3 & 2 & -71.3844 & 42.3313 & 124.0 & 77.0 & -- & 65.0 & 60.0 & 4 & 3 & 122.4 & SS, TR, LI \\
\hline SEA-4 & 2 & -71.3870 & 42.3300 & 143.3 & 80.0 & -- & 68.3 & 63.3 & 4 & 3 & 127.6 & SS, TR, LI \\
\hline SEA-7 & 2 & -71.3877 & 42.3308 & 134.2 & 74.0 & -- & 69.2 & 64.2 & 4 & 3 & 127.9 & SS, LI \\
\hline SEA-8 & 2 & -71.3863 & 42.3305 & 138.3 & 71.0 & 67.3 & 72.3 & 67.3 & 4 & 3 & 127.0 & SS, LI \\
\hline SEA-9 & 2 & -71.3877 & 42.3301 & 139.0 & 112.0 & -- & 39.0 & 34.0 & 4 & 3 & 127.8 & SS, LI \\
\hline TW-1 & 2 & -71.3870 & 42.3299 & 143.3 & 78.0 & -- & 84.3 & 69.3 & 4 & -- & -- & WS, LI \\
\hline TW-2 & 2 & -71.3884 & 42.3305 & 139.0 & 61.0 & -- & 89.0 & 79.0 & 4 & -- & -- & WS, LI \\
\hline TW-3 & 2 & -71.3872 & 42.3306 & 134.2 & 73.0 & -- & 79.2 & 64.2 & 4 & -- & -- & WS, LI \\
\hline TW-4 & 2 & -71.3863 & 42.3305 & 138.3 & 67.2 & -- & 86.1 & 71.1 & 4 & -- & -- & WS, LI \\
\hline WKW-117 & 4 & -71.3730 & 42.3181 & 138.4 & 32.0 & -- & 136.9 & 136.7 & 1 & 14 & 137.6 & SS, LI \\
\hline WKW-118 & 3 & -71.3700 & 42.3225 & 181.0 & 38.0 & -- & 147.5 & 144.5 & 3 & 23 & 153.6 & WL, LI \\
\hline WKW-119 & 3 & -71.3822 & 42.3286 & 175.1 & 65.0 & -- & 117.5 & 114.5 & 2 & 16 & 129.7 & $\mathrm{SS}, \mathrm{TR}, \mathrm{LI}$ \\
\hline WKW-120 & 3 & -71.3714 & 42.3200 & 175.7 & 49.0 & -- & 158.7 & 155.7 & -- & 16 & 165.5 & WL, LI \\
\hline WKW-123 & 3 & -71.3786 & 42.3281 & 150.2 & 100.0 & -- & 53.2 & 50.2 & 4 & 12 & 138.9 & SS, TR, LI \\
\hline WKW-124 & 3 & -71.3786 & 42.3281 & 150.2 & 100.0 & -- & 128.9 & 125.9 & 2 & 12 & 144.2 & TR, LI \\
\hline WKW-2 & 13 & -71.3681 & 42.3144 & 153.8 & 37.5 & -- & 122.8 & 120.8 & -- & -- & -- & LI \\
\hline WKW-27 & 4 & -71.3736 & 42.3194 & 155.0 & 76.5 & -- & 88.6 & 78.6 & -- & 1 & 149.0 & WL, LI \\
\hline WKW-30 & 13 & -71.3883 & 42.3389 & 120.0 & 50.0 & -- & 80.0 & 75.0 & 4 & 1 & 118.8 & SS, LI \\
\hline WKW-52 & 13 & -71.3894 & 42.3425 & 118.0 & 61.5 & -- & 65.0 & 60.0 & 4 & 1 & 117.0 & SS, LI \\
\hline WKW-53 & 11 & -71.3819 & 42.3319 & 135.0 & 91.0 & 44.0 & 54.0 & 49.0 & 2 & 1 & 127.0 & SS, LI \\
\hline WKW-54 & 4 & -71.3831 & 42.3314 & 130.0 & 82.0 & 48.0 & 58.0 & 53.0 & 4 & 1 & 128.0 & SS, LI \\
\hline
\end{tabular}


Subsets of the groundwater-level data were used in model calibration. Groundwater level observations from 65 wells were used in calibrating the steady-state groundwater model. Twelve of these 65 wells have a single measurement, and the remaining have a median of 3 measurements spanning a median period of 30 days. Wells with more than 3 observations had a median difference between the minimum and maximum observations of $2.2 \mathrm{ft}$. Groundwater level observations from 13 wells were used in calibrating the transient groundwater model. A set of groundwater level observations collected during a 2006 aquifer test (SEA Consultants, Inc., 2008) also was used for calibrating both the steady-state and transient models. Many observation wells were excluded from the model calibration because of uncertainty about well locations, land-surface elevations, well depths, or screened intervals.

\section{Water Use}

A permit from the Massachusetts Department of Environmental Protection (MassDEP) is required for all public water-supply withdrawals and for large nonpotablewater withdrawals (industrial and agricultural, for example). The Town of Wayland has the only permitted groundwater withdrawals in the study area and pumps water from three production wells north of the Birch Road well site near the Sudbury River (MassDEP numbers 3315000-03G; -04G; $-05 \mathrm{G}$, labeled HH-1, HH-2, and MV-1, respectively, in fig. 7). These three wells have an average annual combined withdrawal of $1.40 \mathrm{ft}^{3} / \mathrm{s}$, equal to 0.90 million gallons per day (Mgal/d). Monthly average withdrawals peak in July with seasonal high withdrawals from May through September that are 9 to 34 percent greater than the annual average (table 3 ) based on records from 1996-2000 and 2002-2006.

From 1939 to 1979, the Town of Framingham operated wells at the Birch Road site for municipal water supply (fig. 7). The production wells consisted of a cluster of three wells about 1,400 ft north of Lake Cochituate and about $600 \mathrm{ft}$ southeast of the Sudbury River. The wells had a combined pumping capacity of $5.3 \mathrm{ft}^{3} / \mathrm{s}(3.5 \mathrm{Mgal} / \mathrm{d})$ but were likely pumped at a rate closer to $4.9 \mathrm{ft}^{3} / \mathrm{s}$ (SEA Consultants, Inc., 1992). The wells were operated intermittently during the midto late 1970s because of high iron and manganese concentrations, and their use was eventually discontinued in 1979. The town currently obtains all of its water from MWRA from sources outside of the study area. Four large-diameter wells (Birch Road wells, fig. 7) that were installed for aquifer tests in 2005 may become the supply wells for future withdrawals and are treated as such in this study.

Lake Cochituate was the first large drinking-water supply for the City of Boston; the system operated from 1848 through 1951, when it was finally abandoned because of declining quality and the availability of other water sources (http://www.mwra.state.ma.us/04water/html/hist2.htm). Use of Lake Cochituate had been in decline since the early 1900s as new water-supply sources came on line. In 1947, the lake was transferred to the State, and it is now managed by the
Table 3. Average groundwater withdrawal rates from Wayland production wells, 1996-2000 and 2002-2006, Wayland, Massachusetts.

\begin{tabular}{lllll}
\hline \multirow{2}{*}{ Month } & \multicolumn{4}{c}{$\begin{array}{c}\text { Pumping rate } \\
\text { (cubic feet per second) }\end{array}$} \\
\cline { 2 - 5 } & HH-1 & HH-2 & MW-1 & Total \\
\hline Jan. & 0.30 & 0.80 & 0.05 & 1.15 \\
Feb. & 0.46 & 0.60 & 0.09 & 1.15 \\
Mar. & 0.32 & 0.66 & 0.12 & 1.10 \\
Apr. & 0.41 & 0.71 & 0.16 & 1.29 \\
May & 0.56 & 0.78 & 0.18 & 1.52 \\
June & 0.67 & 0.91 & 0.25 & 1.83 \\
July & 0.72 & 0.87 & 0.29 & 1.87 \\
Aug. & 0.58 & 0.87 & 0.24 & 1.69 \\
Sep. & 0.52 & 0.96 & 0.19 & 1.66 \\
Oct. & 0.36 & 0.72 & 0.10 & 1.19 \\
Nov. & 0.40 & 0.55 & 0.16 & 1.11 \\
Dec. & 0.36 & 0.70 & 0.13 & 1.19 \\
\hline Average & 0.47 & 0.76 & 0.16 & 1.40 \\
\hline
\end{tabular}

Massachusetts Department of Conservation and Recreation (MassDCR), 2006). State and local municipalities maintain parks and boat access at several points along the lake for recreational purposes.

Wastewater discharge in the study area varies by town. The towns of Framingham and Natick export wastewater to the MRWA regional wastewater system, which discharges outside of the study area. The towns of Wayland and Sudbury are on private septic systems within the study area and return wastewater locally to the groundwater system.

In the basin upstream of the study area are numerous groundwater and surface-water withdrawals that affect streamflow. Zarriello and others (2010) reported 6 production wells upstream of the study area with total average annual withdrawals of about $4.5 \mathrm{ft}^{3} / \mathrm{s}$ from 1993 to 2003 in the Town of Natick. In the same publication, 24 production wells and 7 surface-water withdrawals were reported to have operated from 1993 to 2003 with a combined annual average withdrawal of about $5.3 \mathrm{ft}^{3} / \mathrm{s}$. The effects of these withdrawals are included implicitly in the groundwater model through specified stream inflows and are particularly evident during periods of low flow.

The operation of surface-water reservoirs upstream of the study area also affects streamflow and can further decrease low-flows during summer months. Three reservoirs in the Sudbury Reservoir system are the largest of these and are actively managed by the MWRA as an emergency supply. Three additional former supply reservoirs farther upstream in the basin are managed by the MassDCR. The operation of these reservoirs, particularly during periods of low flow, can cause large percentage changes in streamflow at the Sudbury River at Saxonville (01098530). 


\section{Groundwater Flow Model}

A numerical groundwater flow model of the aquifer based on MODFLOW-NWT (Niswonger and others, 2011) was developed to represent hydrogeologic conditions and simulate groundwater flow and interaction with surface waters in the study area. MODFLOW-NWT is a finite-difference groundwater modeling software package that is the best available tool for simulating aquifers subject to model cells drying. The groundwater model was developed from our current understanding of the hydrogeology of the study area as part of a multiphase study to address questions about the effects, and the potential to mitigate the effects, of pumping on surfacewater resources, and to identify further needs for data collection and model refinements.

\section{Model Design}

The numerical groundwater model was designed to simulate the complex aquifer system and the interaction of the aquifer with lakes and streams. The model was initially constructed by using MODFLOW-2000 software (Harbaugh and others, 2000) and was later converted to MODFLOW-NWT to prevent numerical instabilities caused by drying and rewetting of model cells. Cell drying is a common problem with models of shallow unconfined glacial-sediment aquifers (DeSimone and others, 2002; Masterson and others, 2009). Numerical instabilities can prevent the model from reaching a solution with acceptably small numerical errors. MODFLOW-NWT uses a numerical formulation that, unlike MODFLOW-2000, keeps aquifer cells active after they are dewatered. In this study, we refer to dewatered cells as "dry cells" with the understanding that they are still active and, in transient simulations, can become wet again.

The model was initially calibrated to long-term steadystate conditions that represent average annual conditions in the study area. After an acceptable steady-state calibration, the model was modified to simulate transient, or unsteady, conditions. Under steady-state simulations, stresses such as recharge from precipitation, groundwater withdrawals, and flow to or from water bodies remained constant, but under transient simulations, these stresses could change in time. The transient model was constructed to represent average monthly conditions, as represented by the observed groundwater levels spanning the period 1931 through 2011.

\section{Discretization}

The total model area (fig. 9) of $9.0 \mathrm{mi}^{2}$ was spatially discretized by a uniform grid of square cells, $50 \mathrm{ft}$ on each side, spanning 360 rows (north-south direction) and 280 columns (east-west direction). This grid size was chosen so that water levels affected by the pumping and the steep bedrock topography near pumping wells could be accurately simulated. The model boundary positions were chosen to correspond with natural no-flow boundaries (no appreciable lateral flows into or out of the model area) or to be sufficiently far from the main areas of interest so that the boundary would have little effect on simulation results.

Vertically, the model was discretized into five layers of variable thickness that represent different aquifer sediments as shown in figure 10. Layer 1 represents the top $10 \mathrm{ft}$ of sediment below the land surface, except in a few areas noted below. Layers 2 through 4 have varying thicknesses representing aquifer sediments that collectively are as much as $261 \mathrm{ft}$ deep. Layer 2 represents permeable sand and gravel deposits near the surface. Layer 3 represents fine lacustrine deposits separating the coarser, more permeable sediments in layers 2 and 4. Layer 4 represents permeable sand and gravel deposits deeper in the aquifer, including those below the fine deposits found at depth in the Lake Cochituate area. In areas where the hydrogeologic units that layers 2-4 represent are absent, a $0.5 \mathrm{ft}$ thickness was assigned to these layers to meet model input requirements. At the margins of the active model area, the total thickness of layers $2-4$ is as little as $1.5 \mathrm{ft}$. Layer 5 (the bottom layer) represents the top $80 \mathrm{ft}$ of bedrock and the mostly thin layer of till over the bedrock. The upper bedrock was included in the model because it is generally more fractured than the deeper bedrock and is considered a zone of active groundwater flow.

Layers 2 and 4 define the principal aquifer in the study area and in some areas are hydraulically separated by the fine deposits represented in layer 3 . The fine-grained component of layer 3 is most extensive in the southern part of the model area under and around Lake Cochituate, pinches out to the north of Lake Cochituate, and does not extend to the Birch Road wells. Layer 3 also represents extensive fine deposits in the northern part of the model area.

Elevations of the land surface at the top of layer 1 were determined for each cell by interpolation of point elevation data derived from 1:5,000 orthophotos (MassGIS, 2003). Layer 1 extends to a depth of $10 \mathrm{ft}$, except in areas where bedrock is close to the surface or where Lake Cochituate is present. Layer 1 thins to $0.5 \mathrm{ft}$ where bedrock is near the surface, mostly along the eastern edge of the active model area. Lake Cochituate, which is up to $65 \mathrm{ft}$ deep, is represented in layer 1 with the thickness determined from bathymetric data.

Layer 2 ranges from 0.5 to $125 \mathrm{ft}$ thick and is thinnest where low-permeability sediments are at the surface in the northern and middle parts of the active model area, at the bedrock island, and in eastern and southwestern boundary cells where bedrock is near the land surface. Layer 3 ranges from 0.5 to $104 \mathrm{ft}$ thick, with the thickest parts in the southern model area. In the northern model area, layer 3 is as much as $86 \mathrm{ft}$ thick. Layer 4 ranges from 0.5 to $208 \mathrm{ft}$ thick and is thickest in the bedrock valley in the southern part of the model. Where layer 3 is $0.5 \mathrm{ft}$ thick, indicating an absence of fines, layers 2 and 4 were assigned a thickness equal to one-half of the remainder of the thickness of the glacial stratified deposits. 


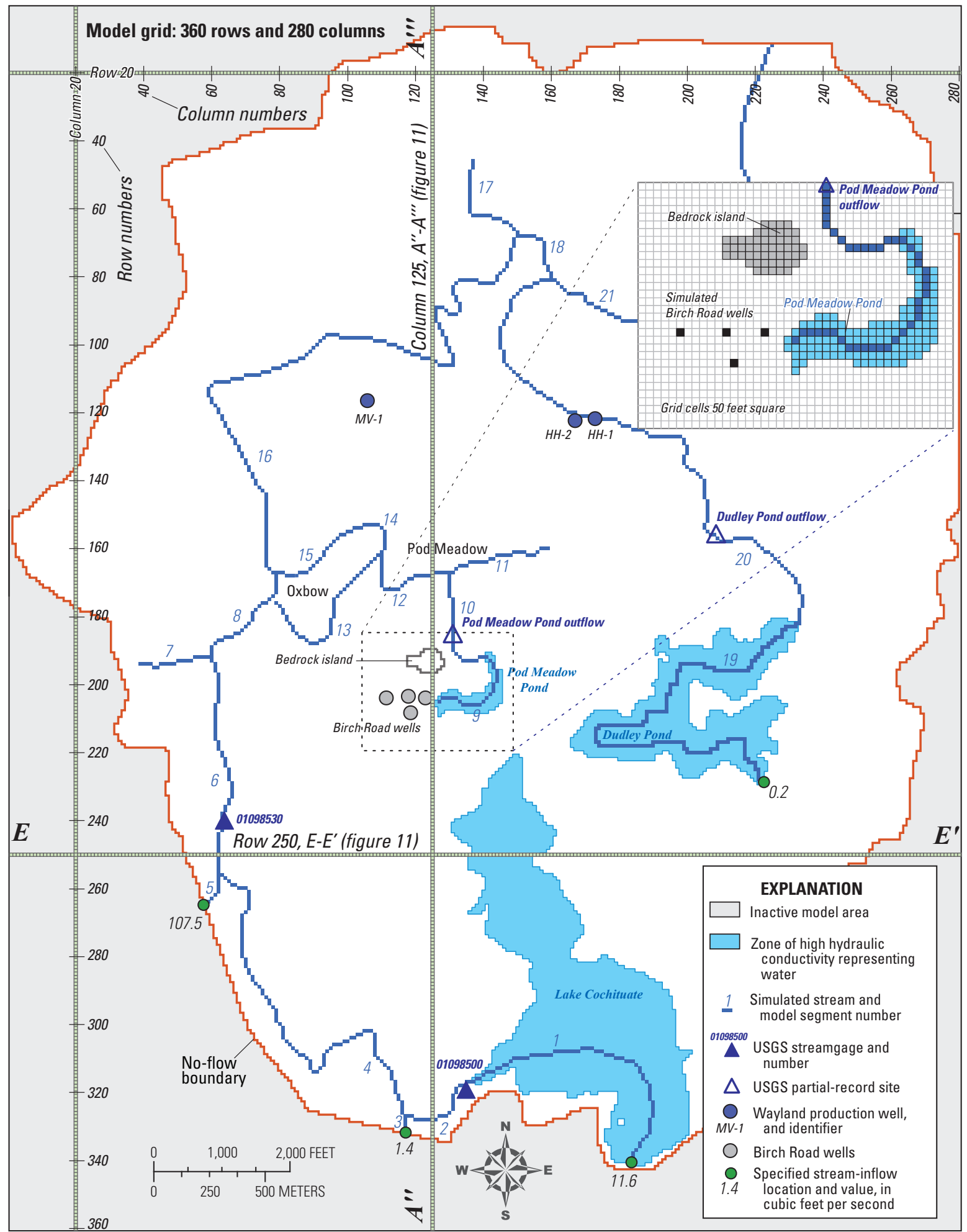

Base from U.S. Geological Survey and Massachusetts Geographic Information System data sources, Massachusetts State Plane Coordinate System, Mainland Zone

Figure 9. Active model area and boundary conditions, east central Massachusetts. 


\section{A. Layer 1}

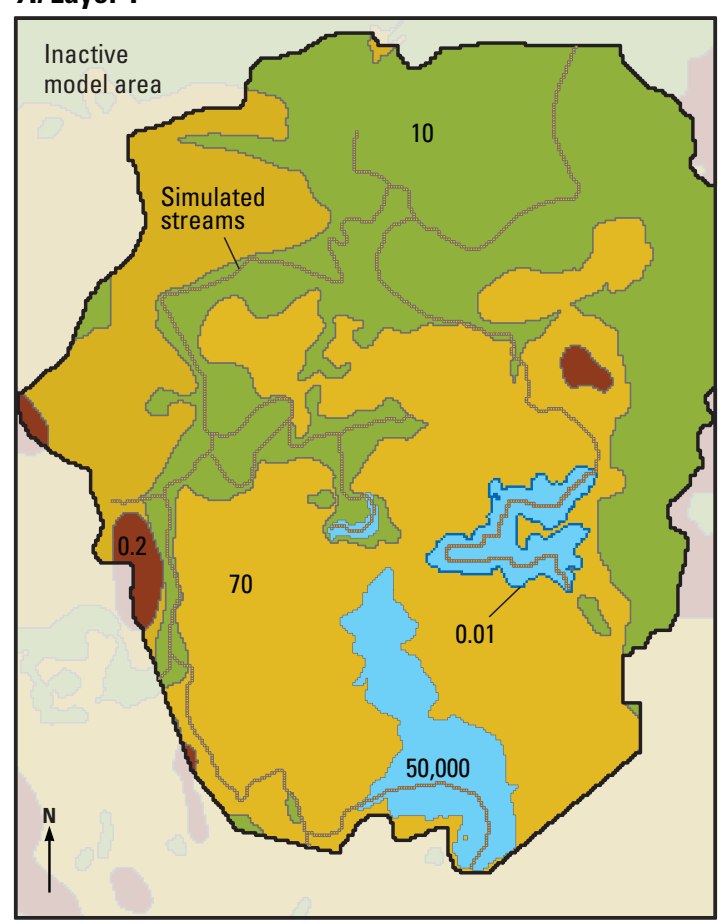

\section{Layer 3}

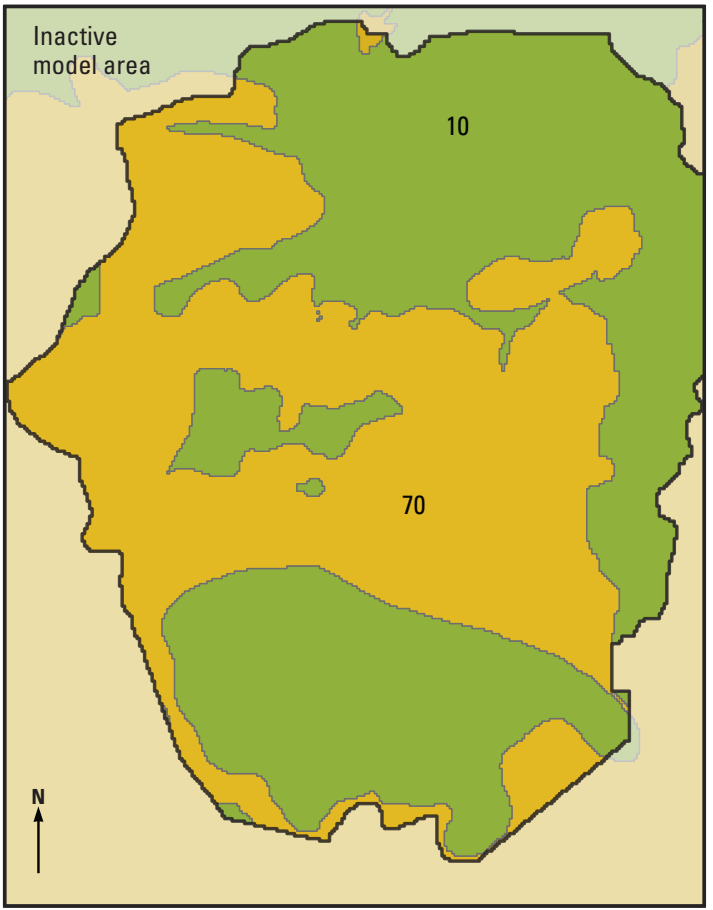

\section{B. Layer 2}

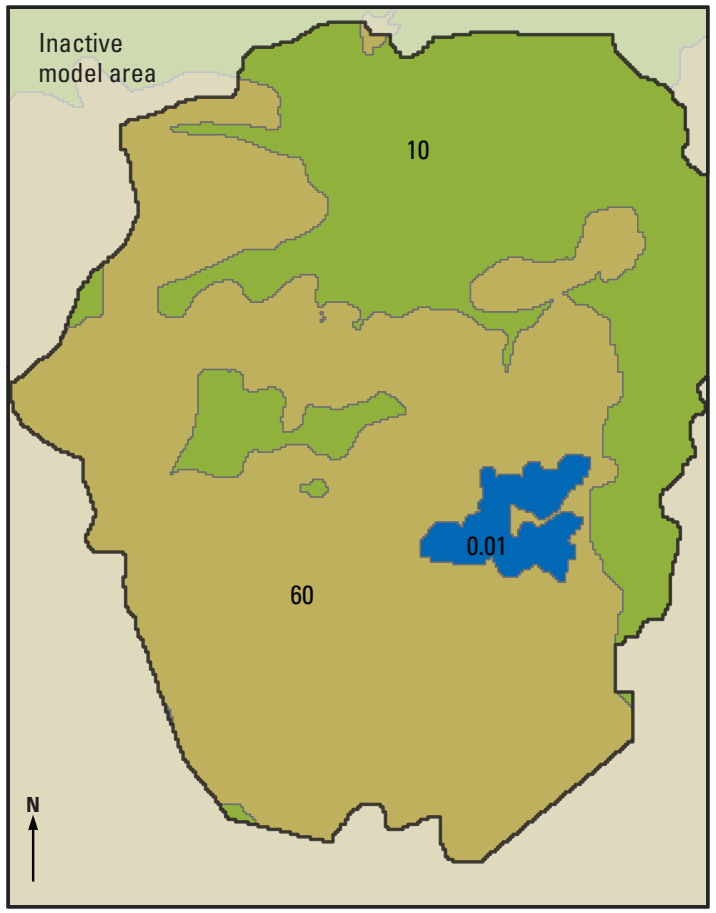

\section{Layer 4}

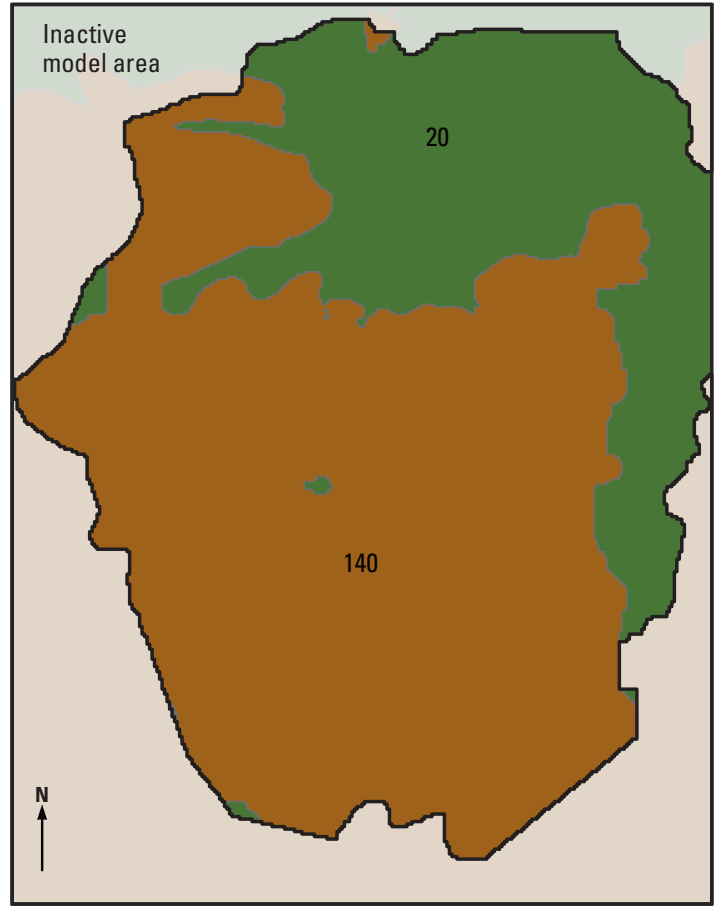

EXPLANATION

Hydraulic conductivity values, in feet per day

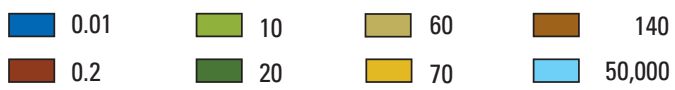

Layer 5 (not shown), constant value of 0.2 feet per day

Figure 10. Variability of hydraulic conductivity values of groundwater-model layers 1-4 used in the calibrated model, east central Massachusetts. Zones defined based on sediment morphosequences (figs. 5, 6), borehole data, and geospatial interpolation. 
Time is discretized in transient simulations to represent month-to-month variability of the annual hydrologic cycle. Transient simulations of the annual cycle were repeated for 5 years to remove the effects of initial conditions and establish a dynamic equilibrium, in which simulated monthly water levels and fluxes are very nearly the same from year to year. Sixty monthly stress periods, representing 5 years of average monthly conditions, adequately established dynamic equilibrium conditions, as indicated by total storage changes of less than 1 percent in the fifth year. Simulation results were reported for the fifth year (months 49-60); results from the first 4 years (months $1-48$ ) were used only to establish a dynamic equilibrium. The one exception to monthly stress periods is a simulation of a 20-day aquifer test, which was used for the transient model calibration described later in the report.

\section{Model Boundaries}

The active model area is surrounded by a no-flow boundary (fig. 9) that generally coincides with surface-water divides and areas of thin sediment. Bedrock is not near the surface at the southwestern and northeastern boundaries, where the Sudbury River enters and exits the model, or at the southern boundary where Lake Cochituate is located. Groundwater flows were assumed to be negligible through sediments underlying the Sudbury River at the model boundaries. At both the southwestern and northeastern boundaries, where the Sudbury River respectively enters and exits the model area, sediments are relatively thin and have relatively low permeability (fig. 4). At the northeastern boundary, surface water gradients are low over a wide wetland area, suggesting that groundwater gradients, and hence flow rates, are also low across the boundary. Further, these areas are far enough from the area of interest that the likely limited groundwater flows through them would have minimal effect on the model simulations.

Inflows to Lake Cochituate were assumed to be fully represented by the assigned stream inflow at the southern end of the lake. Lateral groundwater flow in the sediments beneath Lake Cochituate across the southern model boundary is not likely to be significant because north-south surface-water gradients are low in this area. However, there were few groundwater level observations available to make a full assessment of groundwater flow under the lake. Groundwater flow across the northern boundary is likely small as indicated by the low groundwater table gradient (fig. 7). Further, the potential for this boundary to affect simulation results near the Birch Road wells is minimal because of the large distance between the boundary and the wells. On the basis of observed groundwater levels (fig. 7), the Sudbury River acts as a hydraulic boundary having no groundwater flow beneath it and hydraulically isolating the pumping wells from areas to the west and north of the river. The bottom of layer 5, which is $80 \mathrm{ft}$ beneath the top of bedrock and thin till, is considered an impermeable noflow boundary.
The only exceptions to no-flow boundaries around the perimeter of the active model area are inflows and outflows to streams represented by the streamflow-routing package (SFR2; Niswonger and Prudic, 2005). Flows were specified at the first upstream cell representing the Sudbury River, Dudley Pond (to account for the small drainage area to the pond that is outside the active model area), and a small tributary to Cochituate Brook that has a small drainage area outside the model boundary. Recharge from precipitation was applied uniformly over the model surface through the recharge package (RCH) in MODFLOW-NWT to the highest active model cells. Outflow from the model includes discharge of the Sudbury River at the northeastern boundary, groundwater withdrawals by the Wayland production wells in the northern part of the model, and for some simulations, hypothetical groundwater withdrawals from the Birch Road wells. Outflow by evapotranspiration was not explicitly simulated but was incorporated into the net recharge values used in the model.

\section{Hydraulic Conductivity}

The rate of groundwater flow is determined by hydraulic conductivity and water-level gradients. Hydraulic conductivity of aquifer material was assigned on the basis of sediment lithology (table 4; figs. 10,11). Values were initially adopted from previous studies (DeSimone and others, 2002; Masterson and others, 2009) and then adjusted during model calibration. Each model layer can contain a variety of sediment types in this complex glacial-sediment aquifer, so hydraulic conductivity varied somewhat but was generally uniform within a layer (fig. 10). The ratio of horizontal to vertical hydraulic conductivity (anisotropy) varied by layer from 5 to 20 (table 4). Vertical anisotropy values were initially assigned based on previous studies (DeSimone and others, 2002; Masterson and others, 2009) and then were adjusted during model calibration.

Sand and gravel are the most permeable sediments in the aquifer and were assigned the highest hydraulic conductivity values. Sediments are slightly coarser in layer 4 than in layer 2 and were assigned a hydraulic conductivity value higher in layer 4 than layer 2 . Fine sediment deposits represented by layer 3 contain a wide mix of sediment types but commonly consist of fine sand with silt; hence, these deposits do not represent an aquitard (impermeable boundary to groundwater flow) but rather a more restrictive layer to groundwater flow than the coarse-grain deposits. Bedrock and till in layer 5 were considered slightly permeable for groundwater flow and were assigned a hydraulic conductivity equal to that of fine deposits. The gyttja deposits are generally impermeable and were assigned a low hydraulic conductivity. Gyttja deposits were represented in the model by a low-conductivity layer below Dudley Pond on the basis of the coring study (IEP, Inc., 1983). However, a low-conductivity gyttja layer was not modeled below Lake Cochituate; although gyttja deposits may be present in some areas, no data were available to guide the areal distribution of the layer. 
Table 4. Hydraulic conductivity of aquifer material and storage coefficients by layer in the calibrated model, east central Massachusetts.

[--, no value assigned; bold values indicate the dominant type in the layer]

\begin{tabular}{|c|c|c|c|c|c|}
\hline & Layer 1 & Layer 2 & Layer 3 & Layer 4 & Layer 5 \\
\hline & \multicolumn{5}{|c|}{$\begin{array}{l}\text { Horizontal hydraulic conductivity } \\
\text { (feet per day) }\end{array}$} \\
\hline Sand and gravel & 70 & 60 & 70 & 140 & -- \\
\hline Fines (fine sand, silt, and clay) & 10 & 10 & 10 & 20 & -- \\
\hline Till at surface & 0.2 & -- & -- & -- & -- \\
\hline Bedrock at surface & 10 & 10 & 10 & 20 & -- \\
\hline Bedrock and till at depth & -- & -- & -- & -- & 0.2 \\
\hline Pond muck (gyttja) & 0.01 & 0.01 & -- & -- & -- \\
\hline \multirow[t]{2}{*}{ Lake and pond cells } & 50,000 & -- & -- & -- & -- \\
\hline & \multicolumn{5}{|c|}{ Ratio of horizontal to vertical hydraulic conductivity } \\
\hline \multirow[t]{2}{*}{ Anisotropy } & 5 & 10 & 20 & 10 & 5 \\
\hline & \multicolumn{5}{|c|}{ Storage coefficients } \\
\hline Specific yield (fractional percent) & 0.15 & 0.15 & 0.15 & 0.15 & 0.15 \\
\hline Specific storage ( $1 /$ feet $)$ & 0.00001 & 0.00001 & 0.00001 & 0.00001 & 0.00001 \\
\hline
\end{tabular}

Model cells representing Dudley Pond, Pod Meadow Pond, and Lake Cochituate (layer 1) were assigned a high hydraulic conductivity value of $50,000 \mathrm{ft} / \mathrm{d}$. The high conductivity allows groundwater to move with little resistance between cells, causing groundwater levels to be nearly uniform within the cells, mimicking an open water body. This method of simulating surface water bodies has been analyzed in other studies (Hunt and others, 2003) and used in groundwater models of other northeastern glacial sediment aquifers (Masterson and others, 2009; DeSimone, 2004). In Dudley Pond, where gyttja deposits are well documented (IEP, Inc., 1983), model cells beside and beneath the pond in layers 1 and 2 were assigned a low hydraulic conductivity value of $0.01 \mathrm{ft} / \mathrm{d}$ to maintain a constant water level that matched observed conditions.

\section{Storage Coefficients}

The storage coefficients, specific storage $(S s)$ and specific yield $(S y)$, define the volume of water going in or out of aquifer storage as groundwater levels rise and fall under transient flow conditions. When a model cell is saturated, Ss in units of inverse feet $\left(\mathrm{ft}^{-1}\right)$ is used to define the volume of water released per unit volume of aquifer per unit of groundwater level change. When a model cell is partially saturated, $S y$ (percent) is used and is defined as the volume of water that drains by gravity per unit volume of aquifer. MODFLOW-NWT automatically determines which storage coefficient to use from the simulated water level and top and bottom elevations of each cell. Uniform values were used to define $S s\left(0.00001 \mathrm{ft}^{-1}\right)$ and $S y$ (15 percent) over all model layers (table 4$)$. The values were initially assigned based on aquifer test results (SEA, 1992) and later modified during model calibration.

\section{Streams}

Streams are represented in layer 1 with the StreamflowRouting Package (SFR2) by Niswonger and Prudic (2005). SFR2 simulates flow between streams and the aquifer as a head-dependent flux and tracks streamflow as it moves downstream. Modeled streamflows represent baseflow, the groundwater component of streamflow, and do not include surface runoff or interflow components of streamflow. Simulated streamflow in the model is the combination of specified upstream inflows and groundwater gains or losses to the stream computed by the model. Streams lose water to the aquifer when groundwater levels are below the stream level and gain water when groundwater levels are above the stream level. A stream reach can become dry if stream infiltration into the aquifer exceeds inflow from upstream reaches.

Streams in the model area were defined by 21 segments comprising 1,219 cells in layer 1 that represent the Sudbury River, Cochituate Brook, and minor tributaries, as well as outflows from Dudley and Pod Meadow Ponds and Lake 

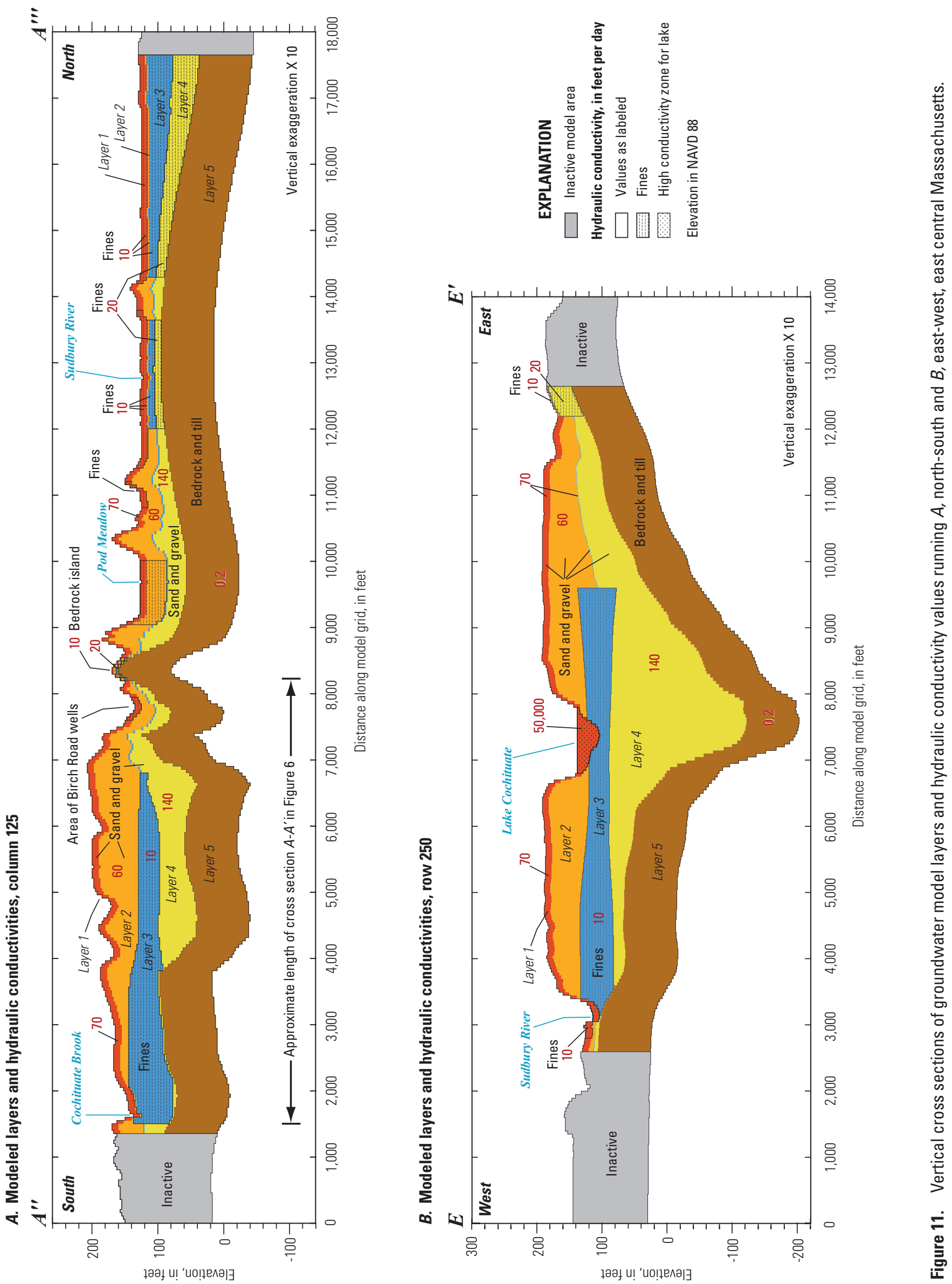
Cochituate (fig. 9). Segments 5, 6, 8, 16, 18, and 21 define the Sudbury River, segments 1, 2, and 4 define Lake Cochituate and its outlet, segments 9-15 define Pod Meadow Pond and its outlet and wetland areas, and segments 19 and 20 define Dudley Pond and its outlet (table 5). Stream cell bottom elevations were determined from the digital elevation data of the land surface minus $1.0 \mathrm{ft}$ to ensure that the channel bottoms were below land surface. Stream cell lengths are equal to the uniform model grid cell size of $50 \mathrm{ft}$, streambed thickness values were set to $1.0 \mathrm{ft}$, while stream widths and streambed hydraulic conductivity varied by stream (table 5). The hydraulic conductivity of the Sudbury River streambed downstream of the oxbow was increased by a factor of 10 relative to hydraulic conductivity upstream of the oxbow to simulate the groundwater/surface-water exchange in the adjoining wetlands and the diffuse shallow stream network in the wetlands. Depths of water in the streams were calculated by the SFR2 package by using a uniform Manning's roughness coefficient of 0.03 .

Stream cells were assigned across the high conductivity zones representing Dudley Pond, Pod Meadow Pond, and Lake Cochituate (fig. 9). These stream cells were assigned streambed elevations equal or close to the average water level of $138.5 \mathrm{ft}$ for Lake Cochituate, $125.8 \mathrm{ft}$ for Pod Meadow Pond, and $153.0 \mathrm{ft}$ for Dudley Pond. Stream cells traversing the lake and ponds drain groundwater when it rises above the stream level but provide a source of recharge to the aquifer when stream levels exceed adjacent groundwater levels.

Inflows were specified to streams entering the active model area on the basis of daily flow records from the
Saxonville streamgage (01098530) from January 1980 through December 2010. For the steady-state model, inflows of 107.5, 11.6, and $1.4, \mathrm{ft}^{3} / \mathrm{s}$ were assigned to the Sudbury River, Lake Cochituate, and the tributary to Cochituate Brook, respectively (fig. 9). These values total slightly less than the median daily flow observed at Saxonville $\left(148 \mathrm{ft}^{3} / \mathrm{s}\right)$ and were proportioned by the drainage area to each boundary inflow point. A small inflow of $0.2 \mathrm{ft}^{3} / \mathrm{s}$ was assigned to Dudley Pond based on the small drainage area to the pond outside of the active model area. Streamflow exits the model through the Sudbury River.

In the transient model simulations, stream inflows were the same for all scenarios and were assigned to represent monthly low-flow conditions. The 75-percent daily flow duration (flow value exceeded 75 percent of the time) was determined for each month of the year from recorded daily flows at the Saxonville streamgage from January 1980 through December 2010. The 75-percent daily flow durations by month at Saxonville were proportioned by drainage area, as previously described, to specify inflows at the model boundary. No inflow was assigned to Dudley Pond for transient simulations. The 75-percent daily flow duration was chosen to represent conservative monthly low-flow conditions throughout the year in addition to the normal seasonal variations in flows. For example, the Sudbury River at Saxonville (01098530) streamgage had a 75-percent daily flow duration for September of $18.0 \mathrm{ft}^{3} / \mathrm{s}$, whereas the 90 -percent daily flow duration for the entire period of record, a commonly used low-flow stress indicator threshold, is 44 percent greater $\left(26.0 \mathrm{ft}^{3} / \mathrm{s}\right)$.

Table 5. Stream segments and properties in the groundwater flow model, east central Massachusetts.

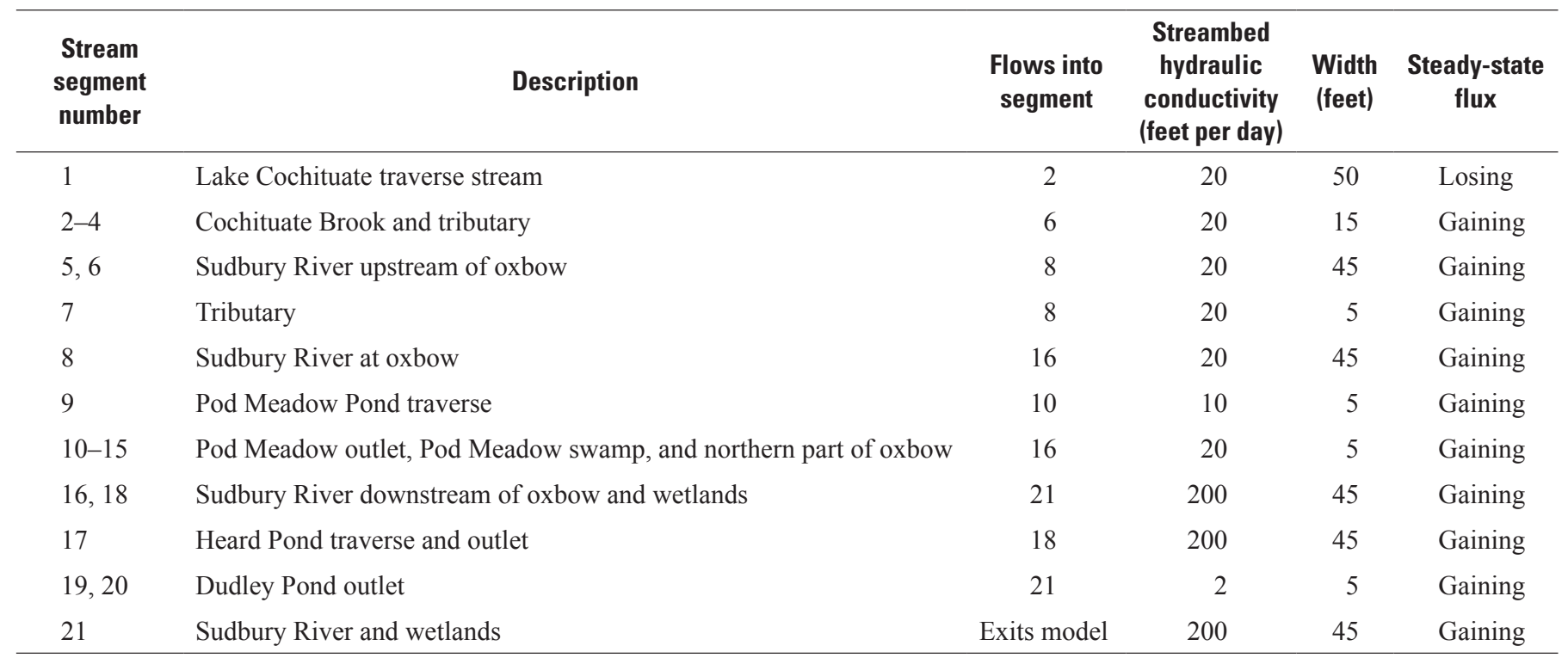




\section{Recharge}

Recharge from precipitation is the primary inflow to the aquifer and was simulated by using the MODFLOWNWT RCH package. Recharge in the steady-state model was assigned a spatially uniform value of $22 \mathrm{in} / \mathrm{yr}$ based on reported values for nearby watersheds (Zarriello and others, 2010; DeSimone, 2004; DeSimone and others, 2002). Recharge was assigned to all active cells except the high conductivity cells representing Lake Cochituate, as these cells were already saturated from the surface-water inflow to the lake and the stream traversing the lake area.

For the transient model, recharge rates were varied monthly to reflect seasonal precipitation and evapotranspiration variability over the year. Monthly recharge rates, as percentages of annual recharge (table 6), were determined from soil moisture budgets calculated with WATBUG software (Wilmott, 1977) by using the Thornthwaite evaporation method from daily temperature and precipitation obtained from the Natick, Mass., weather station (NOAA-COOPID 195175). The recharge rates are similar to values from groundwater studies in a neighboring basin by DeSimone (2004).

\section{Pumping}

Groundwater withdrawal data that were included in all model simulations of the study area were from three production wells operated by the Town of Wayland. Longterm average and monthly average pumping rates (table 3 ) used in the steady-state and transient models were determined from reported 1996-2000 and 2002-2006 values. Hypothetical groundwater withdrawals from the Birch Road wells were included in the model for scenarios described later in the report.

\section{Model Calibration}

Hydraulic parameter values and boundary conditions were manually adjusted to improve the match between simulated and observed groundwater levels, lake levels, and streamflow. Adjustments of hydrologic parameter values and boundary conditions were made within a range of values determined from previous groundwater models of glacialsediment aquifers in Massachusetts. Adjustment of parameters in the NWT solver package also was required to achieve model convergence and reasonable run times (table 7). Calibration efforts were designed to determine the hydrologic controls on groundwater-surface water interaction and to determine areas of data need, rather than to obtain an optimum parameter fit.

\section{Steady-State Calibration}

Steady-state calibration focused on streambed hydraulic conductivity and vertical and horizontal aquifer hydraulic conductivity to reduce simulation errors in pond levels, groundwater levels, and streamflows. Water levels in Dudley Pond, Pod Meadow Pond, and Lake Cochituate were used as calibration targets for the steady-state model (table 8). Lake and pond surface levels were determined from digital landsurface elevation data (MassGIS, 2003) so that they would be consistent with the land-surface elevations used in the model. These levels were given particular attention during calibration of streambed hydraulic conductivity for streams traversing the ponds. Measured streamflows coming out of Dudley and Pod Meadow Ponds (table 9) were also used in calibration of the steady-state model.

For steady-state groundwater model calibration, the mean water-level observations from 65 wells (table 2) were used as calibration targets, and model error was calculated from the simulated minus the observed mean groundwater levels. The variability of groundwater level measurements over different seasons and climatic conditions is a source of uncertainty in developing a long-term steady state representation of water levels. The lack of systematic groundwater observations over time is a source of uncertainty that increases with increased groundwater level variability, fewer observations, and shorter periods of record.

Model cell drying under steady pumping and climatic stresses presented a challenge and in some cases prevented the model from reaching a solution (converging). Convergence problems were addressed by changes to stress periods, time steps, and SFR and NWT input parameters. Under steady-state conditions, most cells in layer 1 dry except in low-lying areas; progressively fewer cells dry in lower layers 2-4 (fig. 12), and no cells dry in layer 5. In the transient model simulations, added pumping stresses and decreased recharge cause additional cells to dry, but cells can also rewet as appropriate.

Table 6. Monthly recharge rates used in the transient groundwater flow model.

\begin{tabular}{lrrrrrrrrrrrrr}
\hline & Jan. & Feb. & Mar. & Apr. & May & June & July & Aug. & Sep. & Oct. & Nov. & Dec. & Annual \\
\hline Inches & 2.3 & 2.4 & 2.8 & 2.5 & 1.6 & 0.8 & 0.7 & 0.3 & 0.6 & 2.5 & 2.1 & 3.3 & 22.0 \\
Percent of annual & 10.6 & 11.1 & 12.9 & 11.4 & 7.1 & 3.8 & 3.0 & 1.3 & 2.8 & 11.4 & 9.7 & 14.9 & 100 \\
\hline
\end{tabular}


Table 7. MODFLOW-NWT input file variable values for NWT package for transient simulations of current conditions (scenario 4).

\begin{tabular}{|c|c|}
\hline Parameter & Value \\
\hline HEADTOL & 0.01 (feet) \\
\hline FLUXTOL & 1,000 (feet per day) \\
\hline MAXITEROUT & 500 \\
\hline THICKFACT & 0.00001 \\
\hline LINMETH & 2 \\
\hline IPRNWT & 1 \\
\hline OPTIONS & Specified \\
\hline IBOTAV & 1 \\
\hline DBDTHETA & 0.7 \\
\hline DBDKAPPA & 0.00001 \\
\hline DBDGAMMA & 0 \\
\hline MOMFACT & 0.1 \\
\hline BACKFLAG & 0 \\
\hline MAXBACKITER & 20 \\
\hline BACKTOL & 2 \\
\hline BACKREDUCE & 0.6 \\
\hline IACL & 2 \\
\hline NORDER & 0 \\
\hline LEVEL & 3 \\
\hline NORTH & 3 \\
\hline IREDSYS & 0 \\
\hline RRCTOLS & $5.00 \mathrm{E}-04$ \\
\hline IDROPTOL & 0 \\
\hline EPSRN & $5.00 \mathrm{E}-04$ \\
\hline HCLOSEXMD & $1.00 \mathrm{E}-03$ \\
\hline MXITERXMD & 150 \\
\hline
\end{tabular}

Streambed vertical hydraulic conductivity influences the timing and magnitude of flows between streams and the aquifer. Reducing streambed conductivity decreases flow between the stream and the aquifer and increases the differences in water level between them. For each stream segment, long-term average groundwater levels in nearby observation wells were used to calibrate the streambed conductivity. For Pod Meadow Pond and Dudley Pond outflows (segments 9 and 19, respectively; fig. 9), the average measured flows (table 1) were also used to calibrate streambed and aquifer hydraulic conductivity values. Streambed conductivity (table 5) was the only stream property adjusted during calibration.

Aquifer hydraulic conductivity values (table 4) were adjusted during the calibration process by changing values according to aquifer material and the layer multiplication factor. Vertical hydraulic conductivity was set by the ratio to horizontal hydraulic conductivity and was fixed at 5.0 for layers 1 and 5 and calibrated for layers 2-4 (table 4). Vertical anisotropy was largely determined by calibration to water levels in paired wells screened in the upper and lower parts of the aquifer.

Pond levels were slightly oversimulated in the steady-state model (table 8). When streambed and aquifer conductivities were calibrated, there was a tradeoff between simulation errors in pond levels, groundwater levels, and outflows from Dudley and Pod Meadow Ponds. Minimizing differences between simulated and observed groundwater levels was given priority over doing the same for pond levels and outflows. The oversimulation of pond levels was considered acceptable because the differences between the simulated and observed levels were well within the observed ranges of natural variability.

Simulated streamflow was evaluated for the stream segments draining Dudley Pond and Pod Meadow Pond by comparing simulated steady-state baseflow in each stream to observed average discharge measurements made from March 2011 to March 2012 (table 1). Simulated flow is about 74 percent higher than observed outflow from Pod Meadow

Table 8. Hydrologic characteristics and observed and simulated water levels of Pod Meadow Pond, Dudley Pond, and Lake Cochituate, east central Massachusetts.

[Observed and simulated levels in North American Vertical Datum 1988. Pond locations are shown in figure 1]

\begin{tabular}{|c|c|c|c|c|c|c|}
\hline \multirow{2}{*}{ Pond } & \multirow{2}{*}{$\begin{array}{l}\text { Drainage area } \\
\text { (square miles) }\end{array}$} & \multirow{2}{*}{$\begin{array}{l}\text { Hydraulic conductivity } \\
\text { of bottom }\end{array}$} & \multicolumn{4}{|c|}{$\begin{array}{l}\text { Water level } \\
\text { (feet) }\end{array}$} \\
\hline & & & $\begin{array}{l}\text { Average } \\
\text { observed }\end{array}$ & $\begin{array}{l}\text { Average } \\
\text { simulated }\end{array}$ & $\begin{array}{c}\text { Difference, } \\
\text { simulated-observed }\end{array}$ & $\begin{array}{c}\text { Observed annual } \\
\text { variation }\end{array}$ \\
\hline Pod Meadow Pond & 0.23 & High & 125.8 & 128.0 & 2.2 & Unknown \\
\hline Dudley Pond & 0.58 & Low & 153.3 & 153.6 & 0.3 & Unknown \\
\hline Lake Cochituate & 17.5 & Mixed & 138.5 & 139.5 & 1.0 & \pm 2.1 \\
\hline
\end{tabular}


Table 9. Simulated flows between Pod Meadow Pond, Dudley Pond, and Lake Cochituate and the aquifer, east central Massachusetts.

[Negative values are outflows from pond]

\begin{tabular}{lccc}
\hline & \multicolumn{3}{c}{$\begin{array}{c}\text { Pond water fluxes } \\
\text { (cubic feet per second) }\end{array}$} \\
\cline { 2 - 4 } & Pod Meadow Pond & Dudley Pond & Lake Cochituate \\
\hline From groundwater & Steady-state current conditions \\
To groundwater & 1.23 & 0.02 & 0.27 \\
Net flux & -0.03 & -0.06 & -1.95 \\
\hline & 1.20 & -0.05 & -1.68 \\
\hline From groundwater & Birch Road wells pumping at 4.9 cubic feet per second \\
To groundwater & 0.93 & 0.01 & 0.17 \\
Net flux & -0.95 & -0.07 & -3.43 \\
Change caused by pumping & -0.02 & -0.05 & -3.26 \\
\cline { 2 - 4 } & -1.22 & -0.01 & -1.58 \\
\hline
\end{tabular}

Pond (1.22 and $0.7 \mathrm{ft}^{3} / \mathrm{s}$, respectively) and 16 percent lower than observed outflow from Dudley Pond $\left(0.67\right.$ and $0.80 \mathrm{ft}^{3} / \mathrm{s}$, respectively). As discussed previously, Pod Meadow Pond outflows are thought to be a result of focused groundwater discharge and, therefore, were a priority in the model calibration, although these flows were difficult to simulate accurately. Oversimulation of Pod Meadow Pond outflows was likely caused by poor model representation of local aquifer hydraulic conductivity patterns around the Birch Road wells and the pond. Outflows from Dudley Pond are largely affected by climatic conditions, as can be seen from the Dudley Pond outflow stream going dry in August 2011 (table 1). Furthermore, because simulated outflows from Dudley Pond reflect the simulation of baseflow but not runoff and interflow, the undersimulation of measured Dudley Pond outflows was not considered unreasonable. Overall, the accuracy of simulated baseflow was considered acceptable for the purposes of this study given the difference between baseflow and total streamflow and the short period of available observations.

Steady-state simulated groundwater levels are generally in agreement with the estimated groundwater table (fig. 14). Groundwater level simulations are acceptably accurate with a mean model error of $-0.45 \mathrm{ft}$, average absolute error of $2.8 \mathrm{ft}$, and a balanced distribution of oversimulated and undersimulated errors (fig. 13).

Not all model error is attributable to limitations of observed data. In some parts of the model area, steady-state simulated and observed groundwater levels did not agree as indicated by spatial patterns of simulation error around the Birch Road well area (fig. 14). The spatial patterns are likely caused by local hydraulic conductivity variations associated with the complex-sediment texture variability in this area. A previous single layer groundwater model of the Birch Road well area (SEA, 2008) included several zones of varying hydraulic conductivity near the Birch Road wells to reduce simulation errors. Hydraulic conductivity patterns assigned to the model in this current study were largely determined from sediment cores and glacial morphosequences, which did not indicate coherent patterns of local-scale hydraulic conductivity variations in the Birch Road well area. Local variations in hydraulic conductivity could be examined in future model modifications by using pilot point or regularization techniques to automate and optimize parameter value assignment. Efforts to remove local error patterns in the Birch Road well area by constructing and calibrating a detailed hydraulic conductivity field were not undertaken in this stage of the study because these errors are not expected to substantially affect answers to study questions.

The calibrated steady-state model also did not accurately reproduce high groundwater levels in some shallow observation wells close to Lake Cochituate that are seen in the map of observed water level measurements (fig. 7). Shallow wells F1W-85, -87, and WKW-27, -118, -120, -124 had high water levels; wells F1W-84 and F1W-88 did not. High observed water levels in some of these wells are thought to reflect locally perched water tables that could be reproduced in the model by lowering hydraulic conductivity values in cells in these areas, but doing so would come at the expense of increased model error at other locations. The borehole sediment logs for these areas did not justify changes to the model hydraulic conductivity values, but future refinements to spatial distribution of hydraulic conductivity could improve the model fit. 


\section{A. Layer 1}

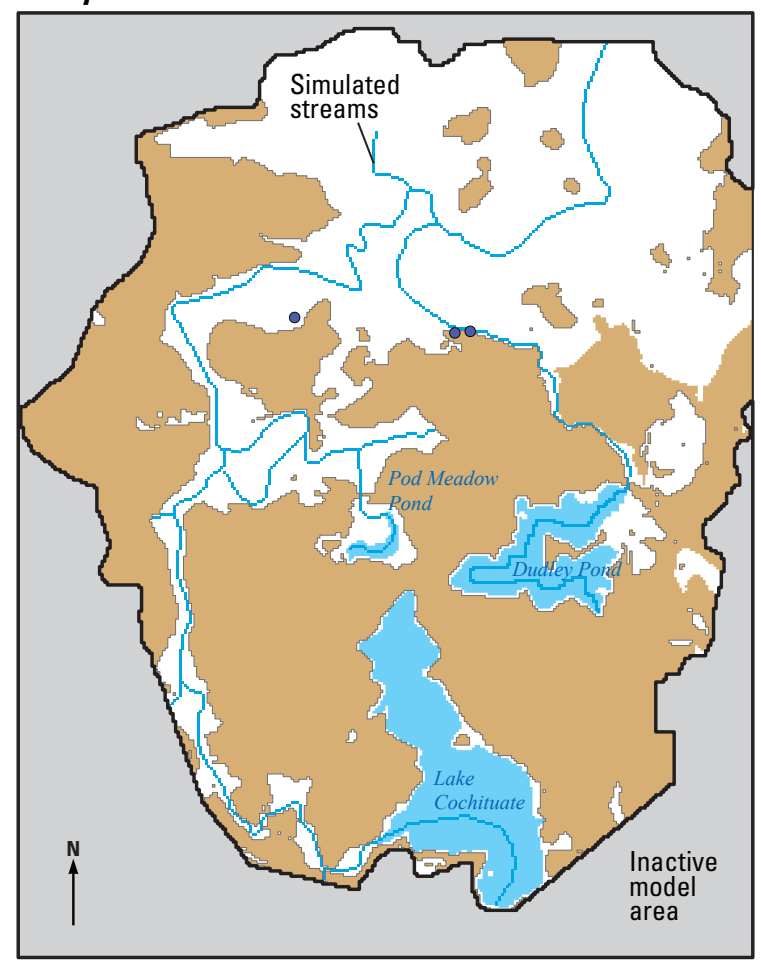

\section{Layer 3}

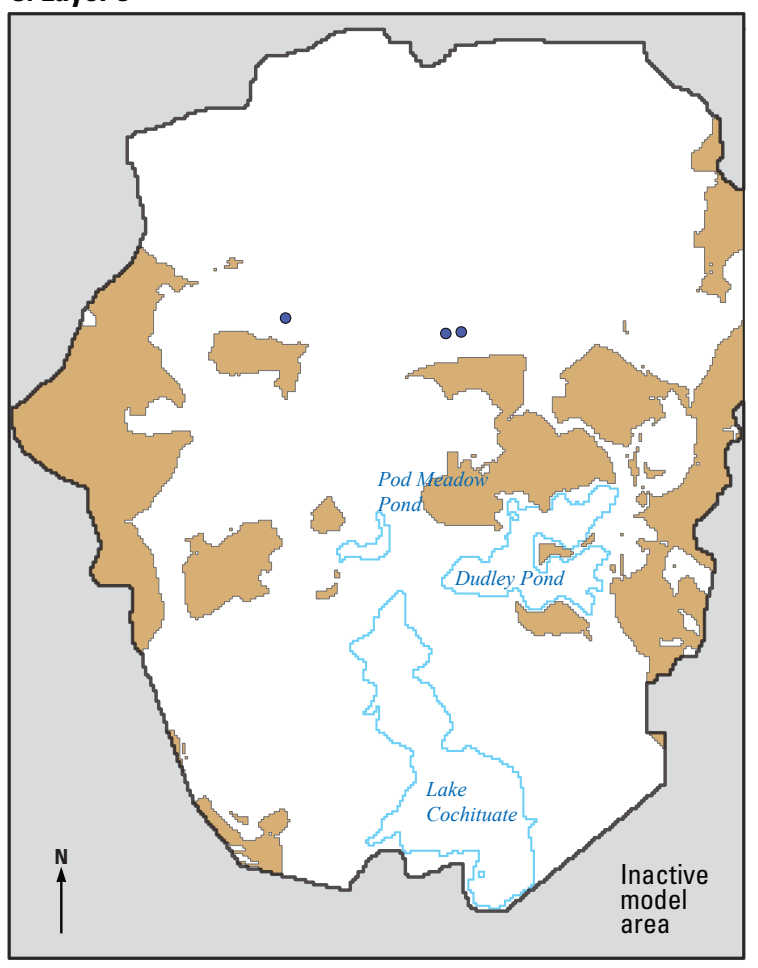

EXPLANATION

\section{B. Layer 2}

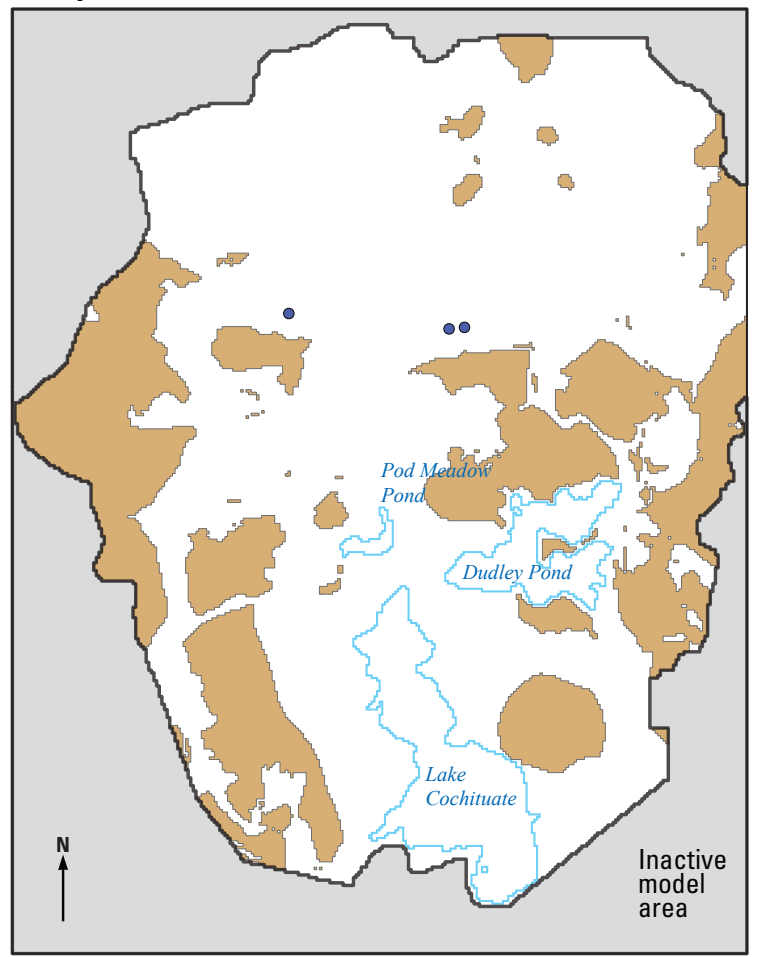

D. Layer 4

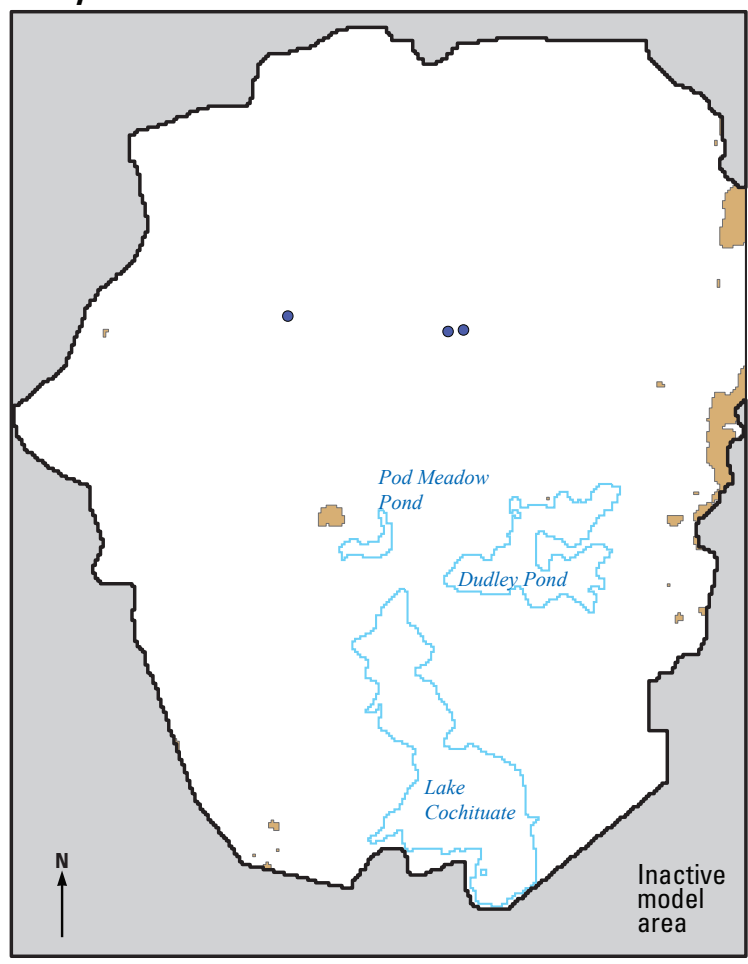

Water bodies in layers 2-4 shown for reference

Figure 12. Model cells in layers 1-4 that dry in the calibrated steady-state model, east central Massachusetts. 


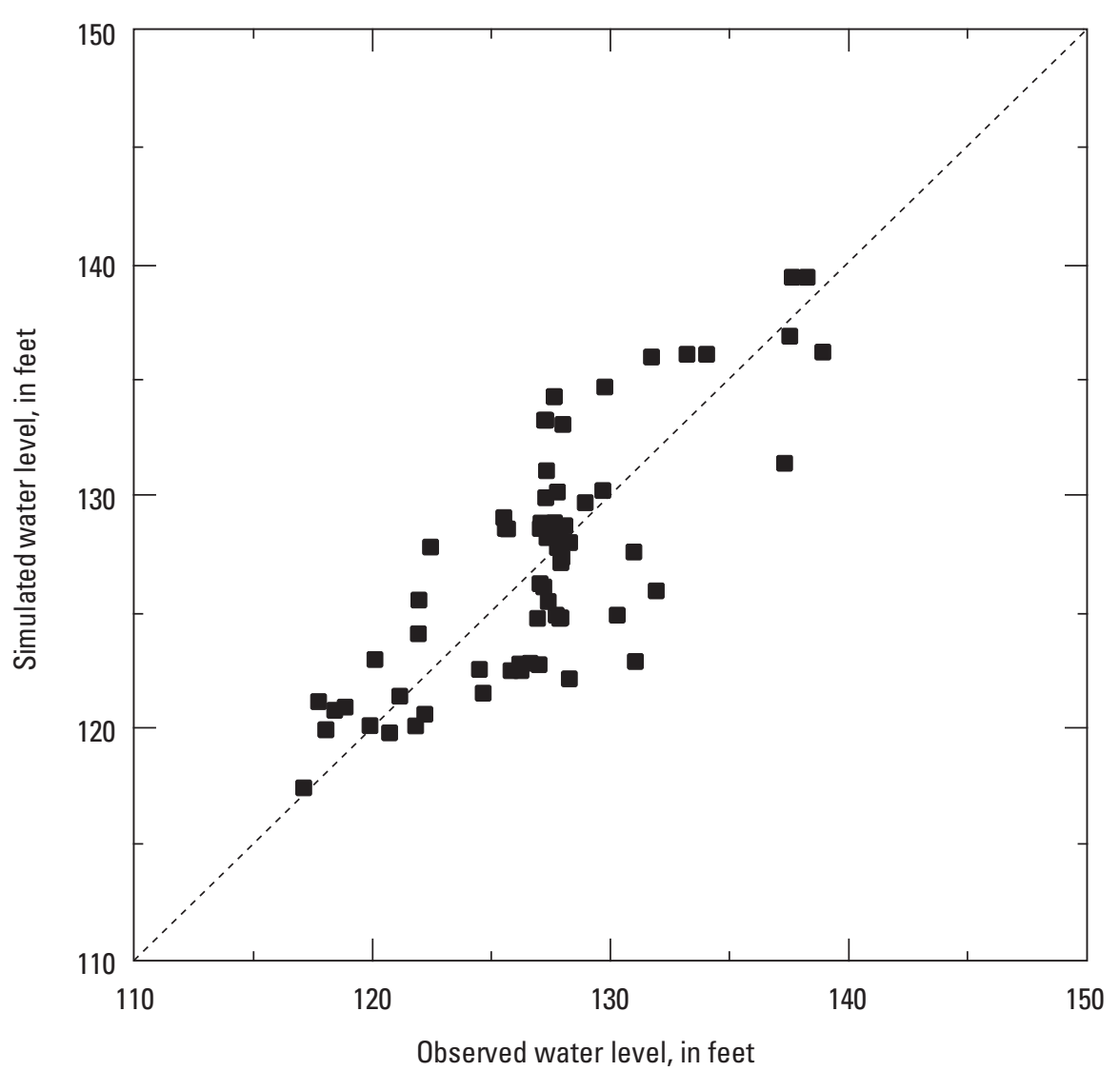

Figure 13. Observed and steady-state simulated groundwater levels, east central Massachusetts.

\section{Transient Model Calibration}

Transient model calibration used data for seasonal groundwater levels and pumping-influenced groundwater levels collected during the 2006 aquifer test, but lake and pond elevations were not used for the transient model calibration because they are strongly affected by surface runoff and evapotranspiration, which were not explicitly simulated. Storage coefficients $S s$ and $S y$ were adjusted during calibration but were assigned uniform values for all layers (table 4). Uniform storage values were assigned because available information does not show consistent relations between $S y$, which is the dominant storage parameter, and sediment texture or hydrogeologic unit.

The transient model was calibrated to observations of ambient groundwater levels made at 13 wells (table 2) that have a minimum of 6 water-level observations taken over a period of at least 150 days. The 13 wells (fig. 15) have a median of 10 observations per well and a median period of record of 346 days. The Head-Observation Package (HOB) by Hill and others (2000) was used to simulate groundwater levels at the times the observations were made, and differences between simulated and observed water levels define simulation error. Initial hydraulic head conditions for the transient simulation were based on steady-state simulated heads. Once the transient model was running, simulated hydraulic heads for the month of January under current conditions were assigned as initial conditions.

The transient model also was calibrated to groundwater level data collected during the April 26-May 15, 2006 aquifer test of the Birch Road wells (SEA, 2008). Transient simulation of the aquifer test (tn50m8) imposed the varying pumping rates of the four wells during the 20-day test. Similar to the other transient simulations, stress periods $1-40$ in run tn $50 \mathrm{~m} 8$ were used to establish only monthly dynamic equilibrium conditions; thereafter, a daily stress period was used (41 through $60)$ to represent the aquifer test. Model boundary conditions (stream inflows, recharge, pumping stresses) were assigned to reflect known conditions during the dates of the test. For example, average April and May recharge rates were applied on the appropriate days. Groundwater drawdowns measured in seven wells (fig. 15) at the end of the test were used for model calibration (table 10).

Simulated transient water levels with no pumping at the Birch Road wells (scenario 1 in table 13) have a mean simulation error of $-0.21 \mathrm{ft}$ and an absolute mean simulation error of $3.55 \mathrm{ft}$ measured by the difference between simulated and observed groundwater levels at 13 observations wells. 


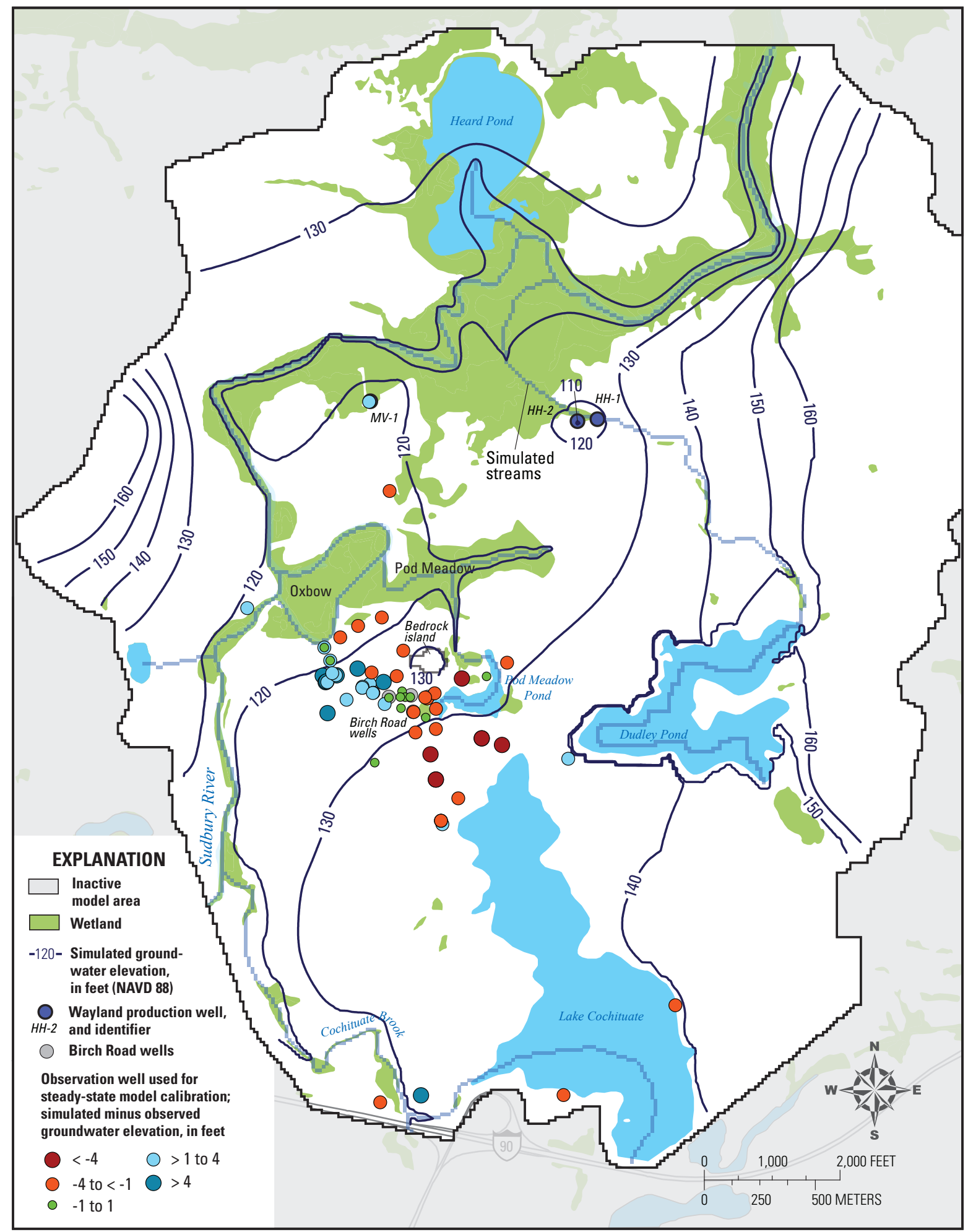

Base from U.S. Geological Survey and Massachusetts Geographic Information System data sources, Massachusetts State Plane Coordinate System, Mainland Zone

Figure 14. Simulated steady-state groundwater levels and errors, east central Massachusetts. 


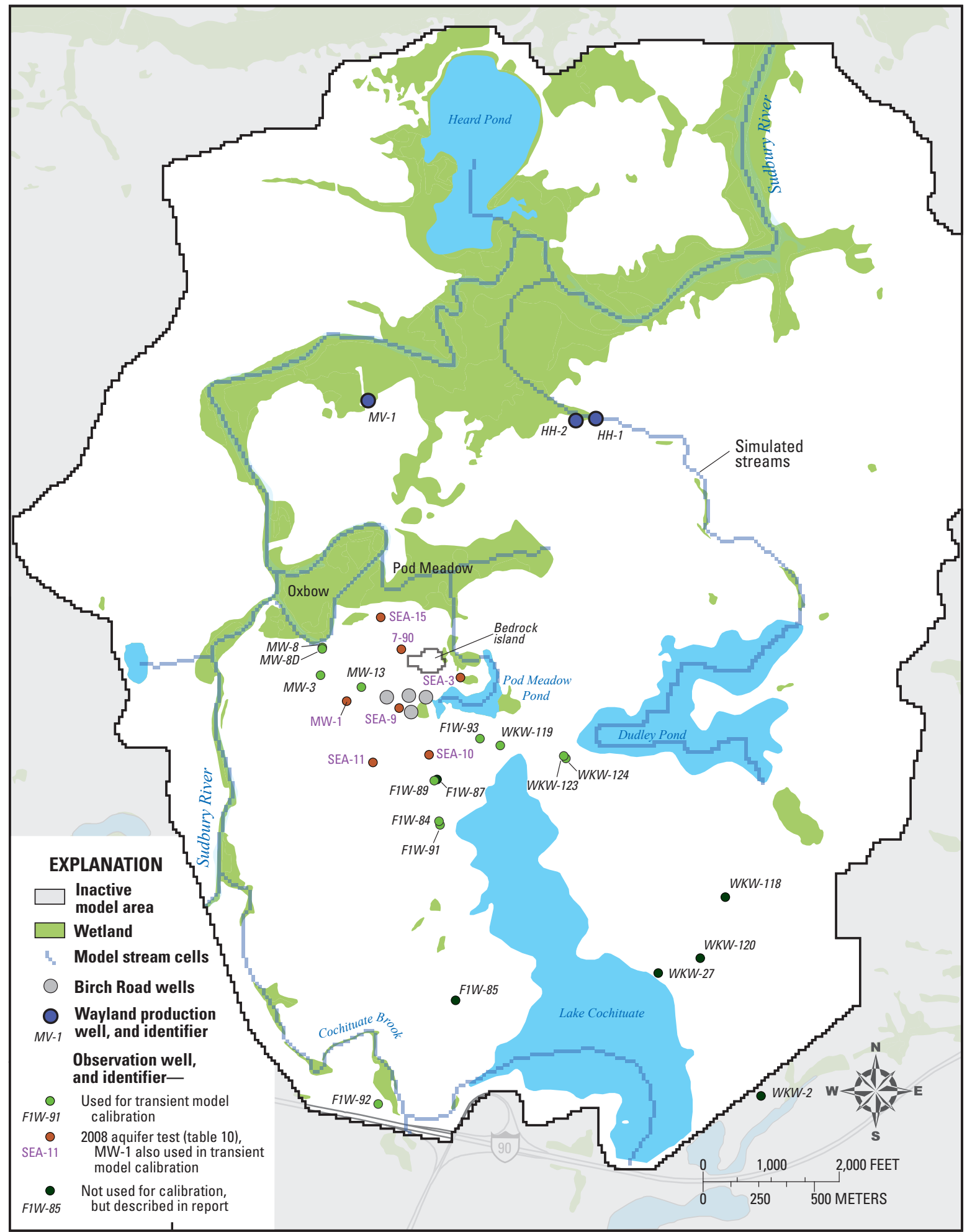

Base from U.S. Geological Survey and Massachusetts Geographic Information System data sources,

Massachusetts State Plane Coordinate System, Mainland Zone

Figure 15. Wells used for transient model calibration of a glacial-sediment aquifer model in east central Massachusetts. 
Table 10. Observed and simulated water levels and drawdowns from aquifer test of the Birch Road wells, east central Massachusetts.

[Aquifer test done in 2006 by SEA Consultants, Inc. (from SEA Consultants, Inc., 2008). Observed and simulated levels in North American Vertical Datum 1988. Well location shown in figure 15]

\begin{tabular}{|c|c|c|c|c|c|c|c|c|}
\hline \multirow[t]{2}{*}{$\begin{array}{l}\text { Observation } \\
\text { well }\end{array}$} & \multirow{2}{*}{$\begin{array}{l}\text { Distance to nearest } \\
\text { pumping well } \\
\text { (feet) }\end{array}$} & \multicolumn{2}{|c|}{$\begin{array}{c}\text { Water level at start of test } \\
\text { (feet) }\end{array}$} & \multicolumn{2}{|c|}{$\begin{array}{l}\text { Water level at end of test } \\
13 \text { days later } \\
\text { (feet) }\end{array}$} & \multicolumn{3}{|c|}{$\begin{array}{l}\text { Drawdown } \\
\text { (feet) }\end{array}$} \\
\hline & & Observed & Simulated & Observed & Simulated & Observed & Simulated & Error \\
\hline $7-90$ & 693.6 & 120.3 & 123.6 & 119.0 & 120.9 & 1.3 & 2.7 & -1.5 \\
\hline MW-1 & 630.4 & 128.3 & 126.6 & 122.4 & 124.2 & 5.9 & 2.4 & 3.5 \\
\hline SEA-10 & 667.1 & 127.9 & 132.6 & 121.8 & 130.3 & 6.1 & 2.3 & 3.8 \\
\hline SEA-11 & 936.7 & 129.5 & 130.4 & 126.6 & 127.6 & 2.9 & 2.7 & 0.2 \\
\hline SEA-15 & $1,193.8$ & 117.7 & 121.9 & 117.3 & 120.6 & 0.4 & 1.3 & -0.9 \\
\hline SEA-3 & 594.2 & 122.5 & 128.0 & 121.6 & 126.1 & 0.9 & 1.9 & -1.0 \\
\hline \multirow[t]{2}{*}{ SEA-9 } & 194.6 & 127.6 & 128.5 & 117.2 & 115.6 & 10.5 & 13.0 & -2.5 \\
\hline & & & & & Means & 4.0 & 3.8 & 0.2 \\
\hline
\end{tabular}

Hydrographs of 4 of the 13 observation wells with the most frequent measurements, 2 near Lake Cochituate and 2 near the well site, indicate reasonable matches to seasonal variability by the transient simulations (fig. 16). The average range of groundwater level variation at a well is simulated to be $1.9 \mathrm{ft}$, while the observed average range is $2.6 \mathrm{ft}$. The difference between the average simulated and observed range is considered acceptable because simulated levels are monthly averages and are expected to have less variation than observed instantaneous levels.

Simulation of the 2006 aquifer test produced groundwater drawdowns that match observations relatively well - water levels were oversimulated at four observation wells and undersimulated at three observation wells (table 10 and fig. 17). Simulated mean drawdown is $3.8 \mathrm{ft}$ as compared to observed mean drawdown of $4.0 \mathrm{ft}$. Mean simulated drawdown error is $0.2 \mathrm{ft}$, and the mean absolute drawdown error is $1.9 \mathrm{ft}$. There is no consistent correlation of simulated drawdown error with the distance from observation well to the nearest pumped well. However, there are spatial patterns in the errors, with wells to the south and southwest of the pumping wells generally having drawdowns simulated too low and wells to the north and northeast generally simulated too high. These patterns may be related to the complex structure of fine and coarse sediment deposits in this area. The simulated rate of drawdown also reasonably matched the observed (fig. 17).

These results indicate that the transient model can reproduce the aquifer test results reasonably well, but that local variability in hydraulic conductivity and perhaps storage coefficients could be improved in the model. Local variability patterns in hydraulic conductivity, particularly within about 1,500 ft to the south and west of Pod Meadow Pond, seem to be causing the spatial patterns of head errors in the steady-state simulations (fig. 14) and aquifer test simulations (table 10).

\section{Model Uncertainty and Sensitivity Analysis}

As with all models, uncertainties in the Framingham groundwater model are inherent because it is a simplification of a complex natural system. Knowledge of which model parameters contribute most to model uncertainty are useful for qualifying model results and the soundness of conclusions drawn from those results and for identifying future data needed to reduce uncertainties. With the research objectives in mind, two measures were chosen for assessing model uncertainty and parameter sensitivity - the rate of induced recharge from Lake Cochituate into the aquifer, and the timing of surface-water response to Birch Road well pumping.

Sensitivity tests included 28 model runs that varied hydraulic model parameters over likely value ranges (table 11). Model parameters were modified individually, with calibrated values multiplied by factors of $0.5,2$, or 10 , depending on their expected range. In some cases, the range of possible parameter values was limited by the model's ability to converge to a solution, in which case the parameter range was narrowed to achieve convergence. For each scenario, changes in induced recharge rate and surface water response time were calculated (table 12). 

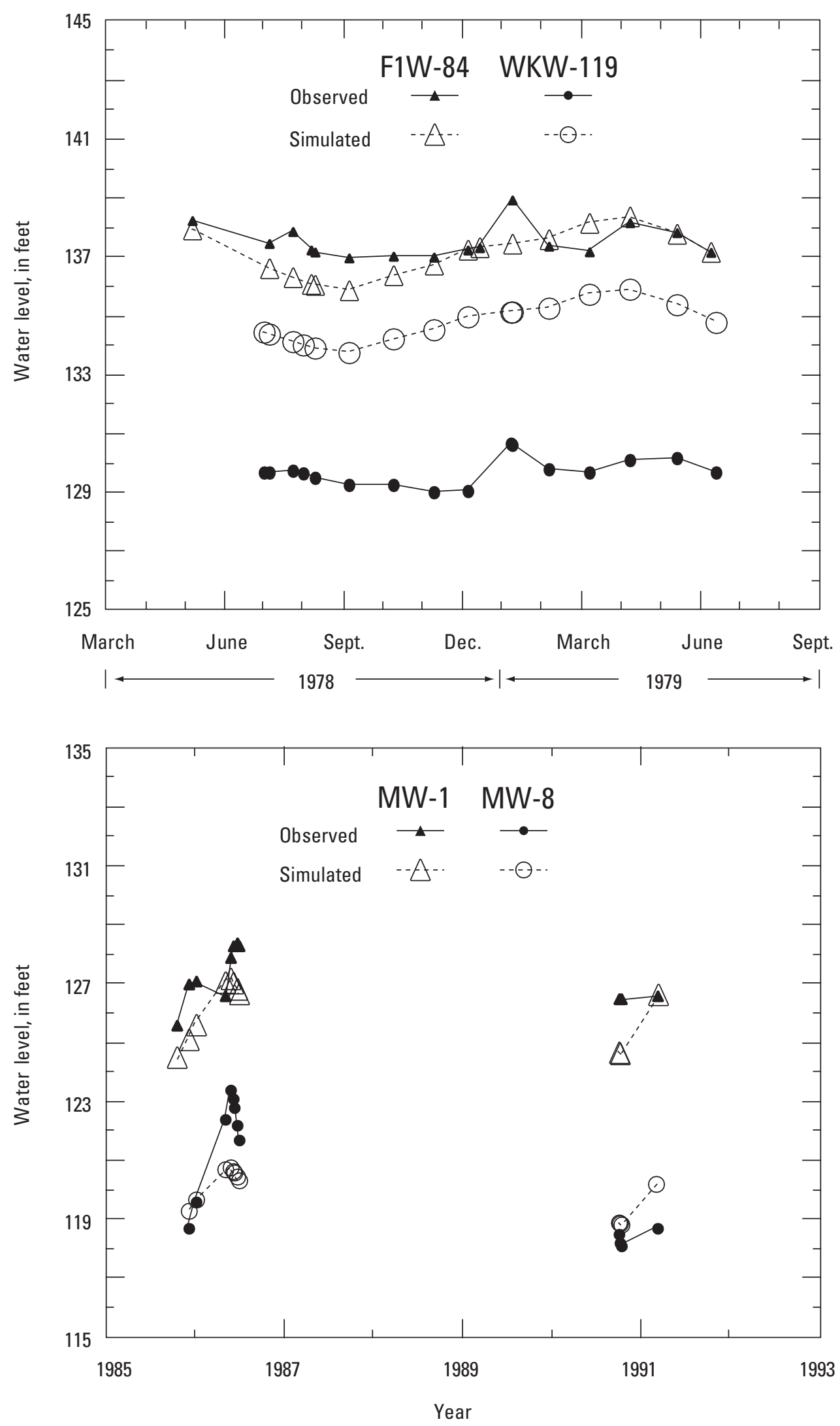

Figure 16. Simulated and observed groundwater hydrographs, under current conditions and no pumping at the Birch Road wells, east central Massachusetts. 


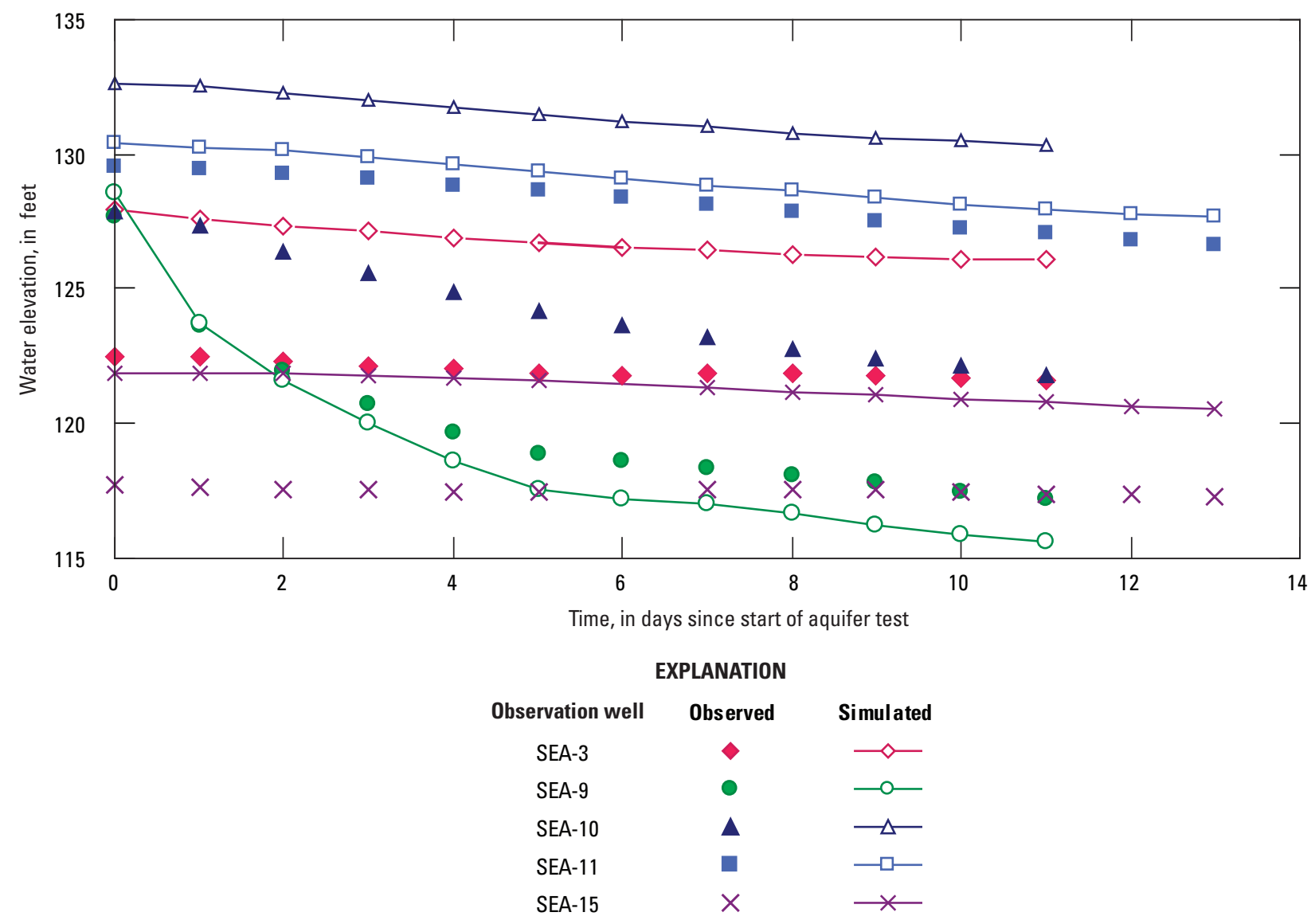

Figure 17. Transient simulation of a 2006 aquifer test made with a daily time step compared to groundwater observations, east central Massachusetts. (Aquifer test by SEA Consultants, Inc., 2008; well locations shown in figure 15)

The sensitivity of induced recharge from Lake Cochituate was calculated by using the steady-state model with long-term average climatic conditions and a hypothetical constant pumping rate of $4.9 \mathrm{ft}^{3} / \mathrm{s}(3.17 \mathrm{Mgal} / \mathrm{d})$ from the Birch Road wells (scenarios n40-n55). ZONEBUDGET (Harbaugh, 1990) was used to determine the rate of induced recharge, or flux, from the high-conductivity cells representing the lake to the surrounding aquifer cells. Variations of induced recharge caused by parameter value changes were calculated relative to the calibrated model (scenario $\mathrm{n} 33 \mathrm{~m} 2$ ).

The sensitivity of surface-water response time was calculated by using transient model simulations with monthly average conditions (scenarios tn52-tn69). Response time $\left(t_{50}\right)$ was defined as the number of days for 50 percent of streamflow depletion to occur following 1 month of pumping from the Birch Road wells at a hypothetical rate of $4.9 \mathrm{ft}^{3} / \mathrm{s}$ $(3.17 \mathrm{Mgal} / \mathrm{d})$. The transient model was run for 5 years (60 months) under average monthly conditions, and the pumps were turned on for 1 month, January of year 4 (month 37).
After the 1 month, the Birch Road wells were turned off and flows continued to be simulated through December of year 5 (month 60). Streamflow depletion in the Sudbury River was calculated at the exit of the model by subtracting each scenario's flow from the corresponding flow in the calibrated transient model with no Birch Road pumping (scenario tn $51 \mathrm{~m}$ ). Because the transient simulations use a 1-month stress period, a linear interpolation was made between monthly responses to estimate the number of days to reach the $t_{50}$ target. For example, if 40 percent of total stream depletion was seen by the end of January, the month of pumping, and 60 percent of total depletion was seen by the end of February, then the $t_{50}$ was interpolated to occur halfway through February and to equal 14 days. Although some slight variation in $t_{50}$ could be expected if the pumps were run in another month than January or under different recharge conditions, the goal here was to assess sensitivity. Transient simulations were also run for scenarios in which pumps are run in other months and under varying recharge conditions. 
Table 11. Model simulations used to determine sensitivity of induced recharge from Lake Cochituate and pumping response times to hydraulic parameter values, east central Massachusetts.

$\left[\mathrm{ft}^{-1}\right.$, inverse feet; --, not tested]

\begin{tabular}{|c|c|c|c|c|c|c|c|c|c|}
\hline \multirow{2}{*}{ Parameters changed } & \multicolumn{3}{|c|}{$\begin{array}{l}\text { Calibrated average model parameter } \\
\text { values and range of values tested }\end{array}$} & \multicolumn{6}{|c|}{ Name of model scenario used to test parameter change } \\
\hline & Calibrated & Lower & Upper & Calibrated & Lower & Upper & Calibrated & Lower & Upper \\
\hline $\begin{array}{l}\text { Average streambed conductance }{ }^{1} \\
\text { (feet per day) }\end{array}$ & 70 & 35 & 105 & $\mathrm{n} 33 \mathrm{~m} 2$ & $\mathrm{n} 40$ & n50 & $\operatorname{tn} 51 \mathrm{~m}$ & $\operatorname{tn} 52$ & $\operatorname{tn} 62$ \\
\hline \multicolumn{10}{|c|}{$\begin{array}{l}\text { Average aquifer hydraulic conductivity' } \\
\text { (feet per day) }\end{array}$} \\
\hline Sand and gravel & 113 & 85 & 226 & $\mathrm{n} 33 \mathrm{~m} 2$ & $\mathrm{n} 41$ & n51 & $\operatorname{tn} 51 \mathrm{~m}$ & $\operatorname{tn} 53$ & $\operatorname{tn} 63$ \\
\hline Fines & 12.5 & 6.25 & 25 & $\mathrm{n} 33 \mathrm{~m} 2$ & $\mathrm{n} 42$ & $\mathrm{n} 52$ & $\operatorname{tn} 51 \mathrm{~m}$ & $\operatorname{tn} 54$ & $\operatorname{tn} 64$ \\
\hline Dudley Pond gyttja & 0.01 & 0.001 & 0.1 & $\mathrm{n} 33 \mathrm{~m} 2$ & $\mathrm{n} 43$ & n53 & $\operatorname{tn} 51 \mathrm{~m}$ & $\operatorname{tn} 55$ & $\operatorname{tn} 65$ \\
\hline Bedrock and till at depth & 0.2 & 0.02 & 2 & $\mathrm{n} 33 \mathrm{~m} 2$ & n44 & n54 & $\operatorname{tn} 51 \mathrm{~m}$ & $\operatorname{tn} 56$ & $\operatorname{tn} 66$ \\
\hline Anisotropy & 10 & 5 & 20 & $\mathrm{n} 33 \mathrm{~m} 2$ & $\mathrm{n} 45$ & n55 & $\operatorname{tn} 51 \mathrm{~m}$ & $\operatorname{tn} 57$ & $\operatorname{tn} 67$ \\
\hline \multicolumn{10}{|c|}{ Storage coefficients changes } \\
\hline
\end{tabular}

${ }^{1}$ Values vary in the model but averages were used to indicate relative change.

Table 12. Changes in induced recharge from Lake Cochituate and streamflow response times resulting from changes in hydraulic parameter values, east central Massachusetts.

[Model parameter changes shown in table 11; --, not tested]

\begin{tabular}{|c|c|c|c|c|c|c|}
\hline \multirow{3}{*}{ Parameter values changed } & \multicolumn{6}{|c|}{ Change in model results in response to parameter value changes } \\
\hline & \multicolumn{3}{|c|}{$\begin{array}{l}\text { Induced recharge rate }{ }^{1} \\
\text { (cubic feet per second) }\end{array}$} & \multicolumn{3}{|c|}{$\begin{array}{c}\text { Streamflow response time }{ }^{2} \\
\text { (days) }\end{array}$} \\
\hline & Calibrated & Lower & Upper & Calibrated & Lower & Upper \\
\hline Streambed conductance & 1.58 & 1.55 & 1.58 & 8.3 & 10.6 & 1.9 \\
\hline \multicolumn{7}{|c|}{ Aquifer hydraulic conductivity } \\
\hline Sand and gravel & 1.58 & -0.33 & 3.94 & 8.3 & No solution & 0 \\
\hline Fines & 1.58 & 1.30 & 1.92 & 8.3 & 7.1 & 3.7 \\
\hline Dudley Pond gyttja & 1.58 & 1.62 & 1.37 & 8.3 & 7.9 & 5.8 \\
\hline Bedrock and till at depth & 1.58 & 1.57 & 1.63 & 8.3 & 10.9 & 0 \\
\hline Anisotropy & 1.58 & 1.58 & 1.25 & 8.3 & 2.6 & 12.9 \\
\hline \multicolumn{7}{|c|}{ Storage coefficients } \\
\hline Specific yield & 1.58 & -- & -- & 8.3 & 0 & 35.4 \\
\hline Specific storage & 1.58 & -- & -- & 8.3 & 16.6 & 7.8 \\
\hline
\end{tabular}

${ }^{1}$ Change from no pumping; negative values indicate reduced flow from lake to aquifer.

${ }^{2}$ Response time defined as time to reach 50 percent of streamflow depletion in the Sudbury River. 
Simulation results indicate that induced recharge from Lake Cochituate is most sensitive to hydraulic conductivity of the sand and gravel materials (induced recharge increases from 1.58 to $3.98 \mathrm{ft}^{3} / \mathrm{s}$ when the average hydraulic conductivity of sand and gravel is increased by a factor of 2) and mildly sensitive to the hydraulic conductivity of fine sediments and anisotropy (table 12). These sensitivities are consistent with the hydrogeologic structure of the model in which layer 1 cells representing Lake Cochituate are underlain by the sand and gravel of layer 2 and the fine sediment of layer 3 . The sensitivity of lake recharge to the hydraulic conductivity of sand and gravel indicates that future data collection efforts should look more closely at lake bed sediments and the sediment units underlying the lake. Information on sediment textures and hydraulic conductivities of deposits underlying Lake Cochituate could improve model accuracy and lessen model uncertainty.

The timing of surface-water response is most sensitive to $S y$, the storage coefficient for partially saturated aquifer cells. Increasing $S y$ from 15 percent, the calibrated value, to 30 percent caused $t_{50}$ to increase from 8.3 to 35.4 days. Decreasing $S y$ from 15 to 10 percent caused $t_{50}$ to decrease from 8.3 to 0 days, meaning that $t_{50}$ was reached within the same month as pumping (January). However, model calculations contained streamflow mass balance errors that were large enough to affect the calculation of $t_{50}$ for run tn58a, so the exact value of $t_{50}$ is uncertain. These mass balance errors were caused by numerical artifacts that, while not large relative to most flows in the model, were large relative to the small differences in streamflow used to calculate $t_{50}$. The timing of surface-water response is also sensitive to hydraulic conductivity of sand and gravel $\left(K_{\mathrm{sg}}\right)$. Increasing average model $K_{\mathrm{sg}}$ from 113 to $226 \mathrm{ft} / \mathrm{d}$ causes $t_{50}$ to decrease from 8.3 to 0 days. The effect of decreasing $K_{\mathrm{sg}}$ could not be assessed because the model becomes numerically unstable unless $K_{\mathrm{sg}}$ is close to or above the calibrated values (average $113 \mathrm{ft} / \mathrm{d}$ ). However, decreasing $K_{\mathrm{sg}}$ would likely cause $t_{50}$ to increase appreciably. The sensitivity of surface-water response time to pumping reinforces the finding that better determination of the hydraulic conductivity of sand and gravel deposits could improve the model accuracy and lessen the model uncertainty. This test also indicates that better information on Sy could improve the model simulation of surface-water response times to pumping.

\section{Model Limitations}

The groundwater model is an imperfect, although still useful, representation of the study area aquifer. The model, as currently configured, is not suited for simulating groundwater variability at spatial scales of less than $50 \mathrm{ft}$ or at time scales of less than 1 month. Variability at scales below these limits is averaged out in the model. However, there are some situations where it can be appropriate to modify the model for simulating finer spatial scales or time scales, as was done to simulate the 20-day aquifer test. Users should keep the following model limitations in mind when using the model to answer questions or design water resource management strategies.

The model simulates Lake Cochituate's exchange of lake water with the aquifer and the effects of groundwater pumping on this exchange through the representation of the lake as a high-conductivity zone. The model does not simulate other parts of Lake Cochituate's water budget and so, by itself, the model cannot simulate lake levels. The model was purposefully constructed without using the LAK package (Merritt and Konikow, 2000) because Lake Cochituate's hydrology is predominately controlled by inflow from its $17.5 \mathrm{mi}^{2}$ upstream watershed and a previous surface water model is available to explicitly simulate the lake (Zarriello, 2010). In addition, the conductivity of bed sediments of Lake Cochituate is not well known, which adds uncertainty to the estimation of the exchange of water between the lake and the aquifer. Future work that combines the groundwater model with the surface-water model of Zarriello and others (2010) could allow groundwater effects to be included in more temporally refined and realistic simulations of streamflows and surface water levels. Unlike other ponds in the model that are assigned $22 \mathrm{in} / \mathrm{yr}$ of recharge, Lake Cochituate is assigned zero recharge. If $22 \mathrm{in} / \mathrm{yr}$ of recharge were assigned to Lake Cochituate, an annual average flow of $0.5 \mathrm{ft}^{3} / \mathrm{s}$ would be added to simulated baseflow. Additionally, in the transient simulations no inflow is assigned to the stream traversing Dudley Pond to represent runoff from the pond's drainage area outside the active model area. These small unassigned recharge and runoff flows do not change the main findings of this study (sources of water to the wells, timing of streamflow response to pumping, and the potential for pumping schedules to ameliorate low flows). If the groundwater model is combined with the surface-water model of Zarriello and others (2010) to simulate full streamflow, assignment of these flows should be revisited. Use of the LAK package within MODFLOW-NWT could help improve simulation of Lake Cochituate's bottom sediments when more data are available to describe its hydraulic properties.

The assumption of no groundwater flow across the northern and southern boundaries of the model is a potential limitation of the model, but few groundwater level measurements are available to confirm the assumption. The balance of evidence indicates there are likely low rates of groundwater flow across these boundaries. This limitation is further tempered by the assignment of streams that provide an alternate route for water to move across these model boundaries. If the model misrepresents no-flow conditions at the boundaries, then pumping stress could potentially draw water through these boundaries and the model would oversimulate the effect of pumping on streamflow. Therefore, the no-flow boundaries are conservative, in terms of simulating the maximum induced streamflow.

Assignment of model parameter values, such as hydraulic conductivity, $S s$, and $S y$, could be improved by using automated parameter estimation methods (Poeter and others, 2005; 
Doherty and others, 2010), which could reduce or remove the spatial patterns in head simulation error around the Birch Road well site. This limitation should be kept in mind if a user wants to make detailed head predictions for this area. Refined hydraulic conductivity assignment around the well site would also likely reduce the oversimulation of baseflow from the Pod Meadow Pond drainage.

Model sensitivity to bedrock hydraulic conductivity perhaps indicates that permeable bedrock is too thick in the model. Future modeling efforts should include adjustment of bedrock thickness to improve calibration and reduce sensitivity. The model is also sensitive to $S y$, which adds uncertainty to findings about the timing of stream response to pumping.

\section{Simulated Aquifer and Streamflow Response}

The calibrated steady-state and transient groundwater models were used to simulate pumping scenarios that address the study objectives (table 13). Water balances and basic features of the hydrologic system were first described from steady-state simulations of average conditions (scenarios 1 and 2). Hypothetical pumping of the Birch Road wells was added to the steady-state model to examine the resulting long-term changes to the water balance and baseflow. Transient model simulations were used to examine the seasonal surface-water response to hypothetical pumping of the Birch Road wells under average (scenarios 3-8) and dry conditions (scenarios 9-13). Alternative pumping schedules were examined by using the transient model to determine how variable pumping schedules can reduce the effects of pumping on surface water.

Dry conditions simulated in scenarios 9-13 are imposed by setting recharge to zero for the months of July, August, and September. Under monthly average conditions, recharge to the aquifer during these three months totals $1.6 \mathrm{in}$. This is a reduction in total annual recharge of only 7.1 percent, but it occurs in the 3-month window before the critical low-flow month of September. The dry conditions, particularly in combination with the low stream inflow values that are specified for all transient simulations, create very low-flow ecologically conservative conditions.

Table 13. Groundwater model scenarios used to evaluate the aquifer and streamflow response to hypothetical withdrawals at the Birch Road wells, east central Massachusetts.

[Yellow shaded cells highlight months of maximum pumping]

\begin{tabular}{|c|c|c|c|c|c|c|c|c|c|c|c|c|c|}
\hline \multicolumn{2}{|c|}{ Scenario } & \multicolumn{12}{|c|}{$\begin{array}{l}\text { Hypothetical pumping of Birch Road wells } \\
\text { (cubic feet per second) }\end{array}$} \\
\hline Number & Name & Jan. & Feb. & Mar. & Apr. & May & June & July & Aug. & Sep. & Oct. & Nov. & Dec. \\
\hline & & \multicolumn{12}{|c|}{ Average recharge conditions } \\
\hline 1 & $\mathrm{n} 33 \mathrm{~m}$ & \multicolumn{12}{|c|}{0} \\
\hline \multicolumn{14}{|c|}{ Transient model scenarios } \\
\hline & & \multicolumn{12}{|c|}{ Average recharge conditions } \\
\hline 3 & $\operatorname{tn} 51 \mathrm{~m}$ & 4.9 & 0 & 0 & 0 & 0 & 0 & 0 & 0 & 0 & 0 & 0 & 0 \\
\hline 4 & $\operatorname{tn} 50 \mathrm{~m} 7$ & 0 & 0 & 0 & 0 & 0 & 0 & 0 & 0 & 0 & 0 & 0 & 0 \\
\hline 5 & $\operatorname{tn} 71$ & 4.9 & 4.9 & 4.9 & 4.9 & 4.9 & 4.9 & 4.9 & 4.9 & 4.9 & 4.9 & 4.9 & 4.9 \\
\hline & & \multicolumn{12}{|c|}{ Dry (low recharge) conditions } \\
\hline 9 & $\operatorname{tn} 85$ & 0 & 0 & 0 & 0 & 0 & 0 & 0 & 0 & 0 & 0 & 0 & 0 \\
\hline 10 & $\operatorname{tn} 81 \mathrm{a}$ & 4.9 & 4.9 & 4.9 & 4.9 & 4.9 & 4.9 & 4.9 & 4.9 & 4.9 & 4.9 & 4.9 & 4.9 \\
\hline 11 & $\operatorname{tn} 82 \mathrm{a}$ & 4.9 & 4.9 & 4.9 & 4.9 & 4.9 & 4.9 & 4.9 & 4.9 & 0.1 & 4.9 & 4.9 & 4.9 \\
\hline 12 & $\operatorname{tn} 83 a$ & 4.9 & 4.9 & 4.9 & 4.9 & 4.9 & 4.9 & 0.1 & 0.1 & 0.1 & 4.9 & 4.9 & 4.9 \\
\hline 13 & $\operatorname{tn} 84$ & 4.9 & 4.9 & 4.9 & 4.9 & 0.1 & 0.1 & 0.1 & 0.1 & 0.1 & 0.1 & 4.9 & 4.9 \\
\hline
\end{tabular}




\section{Steady-State Simulations}

The water balance of inflows and outflows under current and hypothetical conditions indicates the sources of water needed to satisfy withdrawals under average climatic conditions (table 14). Under current conditions (scenario 1), the total inflows to and outflows from the model are $11.5 \mathrm{ft}^{3} / \mathrm{s}$; 83 percent of the inflow is from recharge by precipitation, and the remainder (17 percent) is from stream recharge. Stream recharge is mostly from river cells that traverse Lake Cochituate and lose water to the high-conductivity cells representing the lake. Outflow is mostly discharge to streams ( 88 percent), and the remainder (12 percent) is from withdrawal by the Wayland production wells.

Under hypothetical steady-state pumping of the Birch Road wells (scenario 2), the total inflows to and outflows from the model are $13.1 \mathrm{ft}^{3} / \mathrm{s}$; inflow from recharge by precipitation is the same as before, but decreases as a percentage of the total inflow (73 percent), whereas recharge from streams increases (27 percent). Increased recharge from streams is mostly from induced infiltration of stream water from stream cells traversing Lake Cochituate (table 5, fig. 9). Most outflow from the model is still discharge to streams (52 percent) but decreases from 10.1 to $6.8 \mathrm{ft}^{3} / \mathrm{s}$ compared to no pumping of the Birch Road wells in scenario 1. Withdrawals from the Wayland and the Birch Road wells account for 11 and 37 percent of the total outflow from the model under average steady-state conditions, respectively. It should be noted that although pumping intercepts groundwater that would otherwise discharge to the

Table 14. Steady-state simulated water budgets with and without hypothetical Birch Road well withdrawals, east central Massachusetts.

\begin{tabular}{|c|c|c|}
\hline Water balance & $\begin{array}{c}\text { Current } \\
\text { conditions } \\
\text { (scenario 1) }\end{array}$ & $\begin{array}{c}\text { Birch Road wells } \\
\text { pumping at } \\
4.9 \text { cubic feet } \\
\text { per second } \\
\text { (scenario 2) }\end{array}$ \\
\hline \multicolumn{3}{|c|}{$\begin{array}{c}\text { Inflows } \\
\text { (cubic feet per second) }\end{array}$} \\
\hline Recharge from precipitation & 9.5 & 9.5 \\
\hline Recharge from streams & 2.0 & 3.6 \\
\hline Total & 11.5 & 13.1 \\
\hline \multicolumn{3}{|c|}{$\begin{array}{c}\text { Outflows } \\
\text { (cubic feet per second) }\end{array}$} \\
\hline Pumping & 1.4 & 6.3 \\
\hline Discharge to streams & 10.1 & 6.8 \\
\hline Total & 11.5 & 13.1 \\
\hline Mass balance error & 0.0 & 0.0 \\
\hline
\end{tabular}

stream system, average annual streamflow in the Sudbury River at the Saxonville streamgage (01098530) is $205 \mathrm{ft}^{3} / \mathrm{s}$. Hence, on average, the hypothetical $4.9 \mathrm{ft}^{3} / \mathrm{s}$ withdrawal from the Birch Road wells accounts for only a little over 2 percent of average daily Sudbury River streamflow. Concern arises during low-flow conditions when water use and regulation represent an increasingly large proportion of the total streamflow. The potential effects of the additional stress on Sudbury River low flows from Birch Road well withdrawals were addressed by transient model simulations.

Pumping induces additional recharge to the aquifer system from Lake Cochituate. Imposing a hypothetical constant pumping rate of $4.9 \mathrm{ft}^{3} / \mathrm{s}(3.17 \mathrm{Mgal} / \mathrm{d})$ at the Birch Road wells (scenario 2) induces additional recharge from Lake Cochituate at a rate of $1.6 \mathrm{ft}^{3} / \mathrm{s}$, which is about equal to 32 percent of the hypothetical pumping rate (table 9). Under constant pumping, Dudley Pond receives slightly less groundwater discharge from the aquifer, but more significantly, groundwater discharge to Pod Meadow Pond is almost entirely captured by the pumping wells.

A fundamental principle of the steady-state groundwater model is the requirement that inflows must equal outflows; in a transient model inflows must equal outflows plus or minus changes in storage. A natural consequence of this requirement, without a change to the boundary conditions, is that groundwater discharge to streams must decrease by the amount of groundwater pumped from wells in steady-state simulations. The extent to which a particular stream reach is affected by withdrawals depends on its relative location to pumping wells and on neighboring hydrologic and boundary conditions. Streams upgradient of pumping wells experience little or no baseflow reduction, whereas streams close to and downgradient from the pumping wells experience greater reduction. As a percentage of the imposed pumping $\left(4.9 \mathrm{ft}^{3} / \mathrm{s}\right)$, the reduction of baseflow in streams (scenario 2) is illustrated by the width of the stream lines shown in figure 18. Streamflow depletions in the Sudbury River, equal or nearly equal to the constant $4.9 \mathrm{ft}^{3} / \mathrm{s}$ pumping rate, occur downstream of the oxbow. The stream traversing Pod Meadow Pond (segment 9) experiences the greatest percentage of streamflow reduction (100 percent) as streamflow goes to zero under the steady-state imposed pumping rate of $4.9 \mathrm{ft}^{3} / \mathrm{s}$; this reduction is not visible on figure 18 because it falls below the display threshold value of $1.5 \mathrm{ft}^{3} / \mathrm{s}$.

\section{Transient Model Simulations}

Transient model simulations demonstrate the dynamic response of the groundwater and surface-water interaction to variable pumping rates under seasonal and low-flow recharge conditions. All the transient scenarios (scenarios 3-13) take a conservative approach to streamflow simulation by specifying inflow to stream segments at the model boundary as the 75-percent daily flow duration for each month. All transient scenarios also simulate each of the Wayland wells pumping 


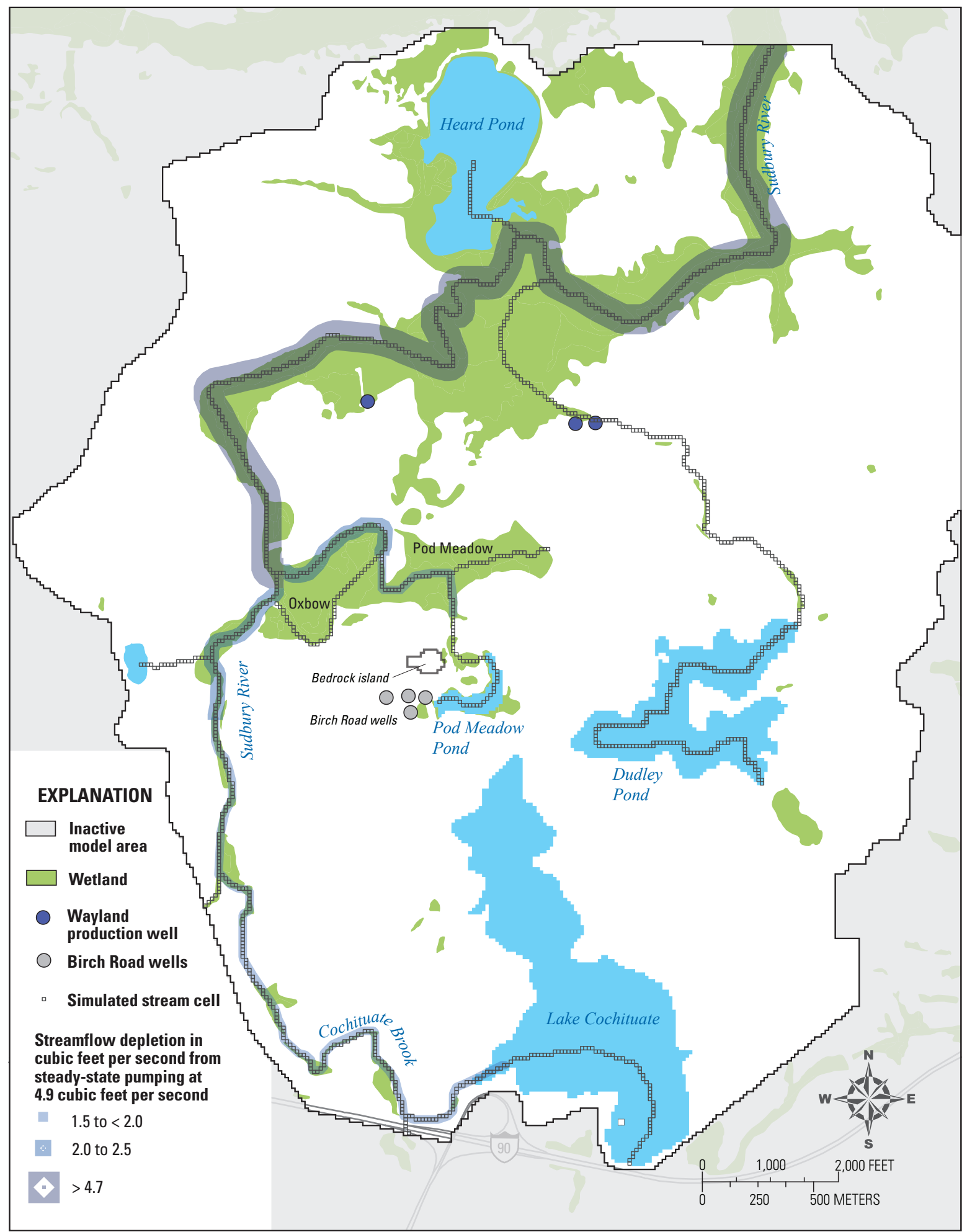

Base from U.S. Geological Survey and Massachusetts Geographic Information System data sources, Massachusetts State Plane Coordinate System, Mainland Zone

Figure 18. Baseflow reduction (streamflow depletion) in stream-channel segments in response to simulated pumping at the Birch Road wells at a constant rate of 4.9 cubic feet per second ( 3.17 million gallons per day), east central Massachusetts. 
at the average reported monthly rate. When applicable to the scenario, pumping of the Birch Road wells was distributed among the four wells developed for the 2006 aquifer test by SEA Consultants, Inc. (2008).

Under monthly average conditions, with no pumping of Birch Road wells (scenario 4), water is lost from aquifer storage from May through September and replenished from October through April (fig. 19). A few stream segments, primarily the stream traversing Lake Cochituate, provide recharge to the aquifer throughout the year from a maximum of 29 percent in September to a minimum of 10 percent in December, when recharge from precipitation is at its normal annual lowest and highest levels, respectively. Discharge to streams is the primary outflow from the aquifer, although in September pumping from Wayland wells accounts for 18 percent of total outflow from the aquifer when discharge from the aquifer to streams is at its seasonal low. Under average monthly recharge conditions, simulated discharge from the aquifer to streams is lowest during August and September and highest in April and May (fig. 19).

\section{Evaluation of Pumping Strategies to Reduce Low-Flow Stresses}

The transient model was used to determine the timing of surface-water response to pumping and to evaluate pumping strategies to reduce the effects of pumping during low-flow conditions. The timing of surface-water response to pumping is characterized by the results from scenario 3, in which the Birch Road wells are simulated as pumping at $4.9 \mathrm{ft}^{3} / \mathrm{s}$ for 1 month, and subsequent streamflow depletions are determined (fig. 20). Associated streamflow depletions start in the same month as pumping and dissipate quickly after the pumping stops because of the high permeability of the aquifer and the proximity of streams to the pumping wells. As soon as pumping stops, the reduction of baseflow, or in other

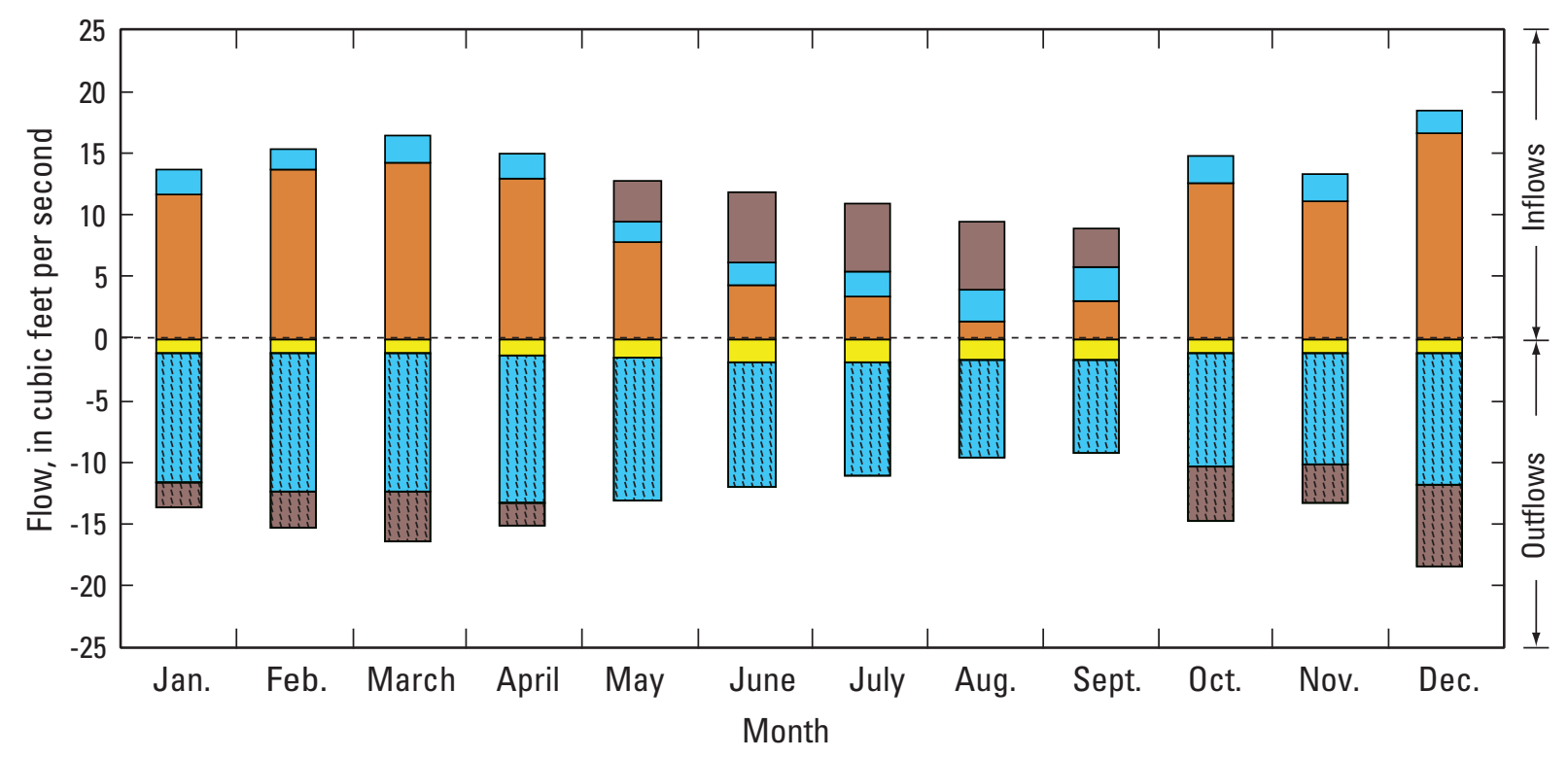

EXPLANATION

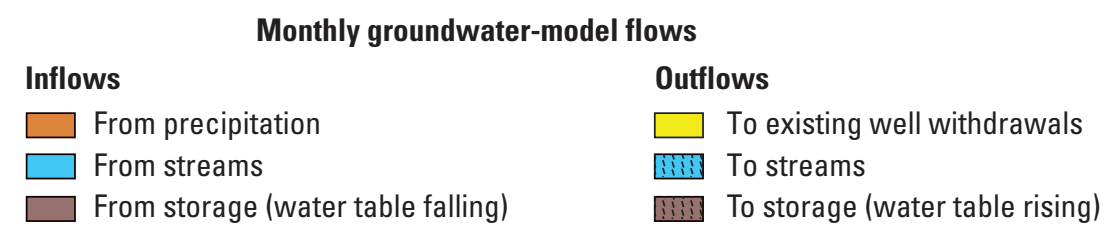

Note: As storage decreases (water table falls) it creates inflow to the active groundwater system, and as storage increases (water table rises), it creates an outflow from the active groundwater system. Inflows from precipitation are net, accounting for evapotranspiration losses.

Figure 19. Simulated transient monthly water budget under current average monthly conditions (no pumping of Birch Road wells), east central Massachusetts. 


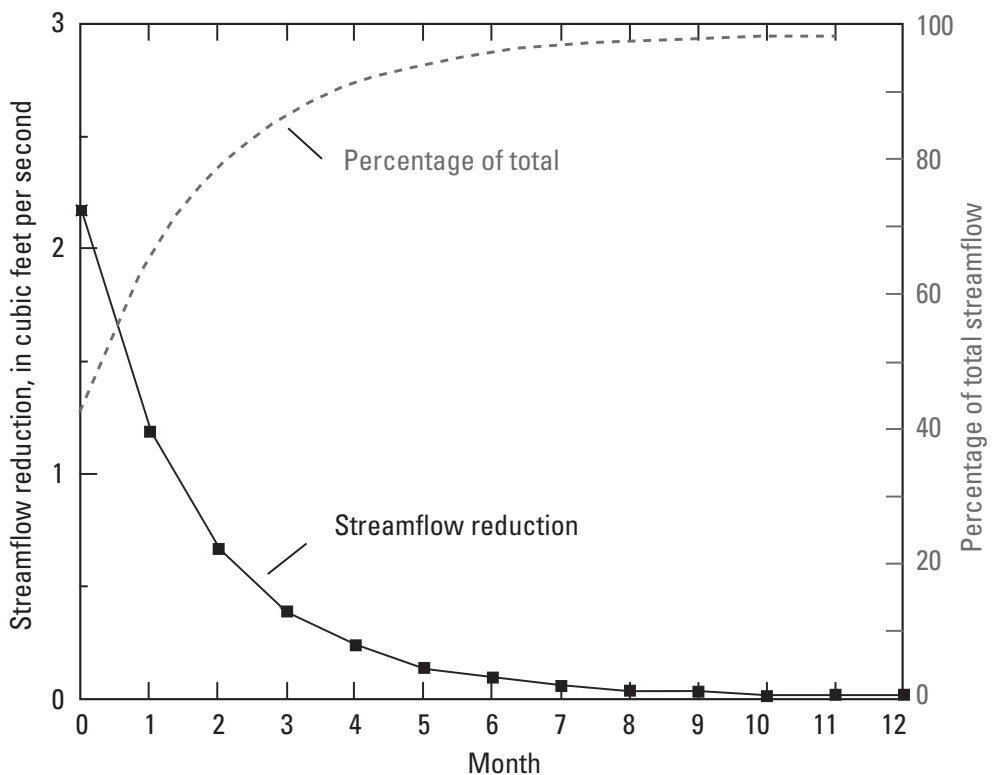

Figure 20. Simulated streamflow response of the Sudbury River after 1 month of pumping the Birch Road wells at 4.9 cubic feet per second $(3.17$ million gallons per day), east central Massachusetts. words streamflow depletion, decreases by about 40 percent. Within 2 months, the reduction of baseflow decreases by about 80 percent, and within 4 months, by about 90 percent (fig. 20). The fast response of surface water to pumping stresses indicates the potential for pumping to be managed to reduce streamflow depletions during periods of low flow.

Alternate pumping schedules and rates were simulated with the transient model (table 13) to evaluate possible strategies to reduce the impacts of pumping on surface water during average seasonal low flows (scenarios 4-8) and during more extreme dry conditions (scenarios 9-13). Scenarios 4 and 9 set baseline conditions for average and dry climatic conditions, respectively, in which there was no simulated pumping at the Birch Road wells. Scenarios 5 and 10 simulated the Birch Road wells pumping at a constant rate of $4.9 \mathrm{ft}^{3} / \mathrm{s}$. Scenarios 6-8 and 11-13 simulated a reduced pumping rate of $0.1 \mathrm{ft}^{3} / \mathrm{s}$ for 1,3 , and 6 months of the year and a pumping rate of $4.9 \mathrm{ft}^{3} / \mathrm{s}$ in the remaining months. A minimum pumping rate of $0.1 \mathrm{ft}^{3} / \mathrm{s}$ was used because the pumped water requires treatment, and this is the estimated minimum pumping rate required to keep a treatment facility operational without a major shutdown and startup (Peter Newton, Bristol Engineering Advisors, Inc., written commun., December 2011).

Alternative pumping schedules were chosen as examples of how these rates could affect the usual seasonal cycle of low summertime streamflows. In actual operation, pumping rates could be determined from streamflow, weather forecasts, upstream reservoir operations, or other criteria, but for this analysis reductions in pumping the Birch Road wells were limited to 1, 3, and 6 months of the year. Simulated monthly flows in the Sudbury River at the model exit under average monthly climatic conditions and various pumping scenarios (scenarios 5-8) show small changes between pumping and no-pumping scenarios during normal seasonal high recharge (December through May); however, changes are noticeable by September (table 15, fig. 21). The greatest reduction in streamflow occurs from July through September when pumping continues throughout most of the year (scenarios 5 and 6). Reduced pumping for 3 and 6 months of the year (scenarios 7 and 8) keeps baseflow nearly the same as without pumping. Simulated baseflow under dry recharge conditions is only slightly less than simulated baseflow under average recharge conditions.

Streamflow depletion increases going downstream in the Sudbury River as the effects of pumping accumulate (fig. 22). At approximately $1.0 \mathrm{mi}$ downstream from the model entrance, where drainage from the Pod Meadow area enters the Sudbury River, effects of pumping noticeably increase, and streamflow depletion nearly reaches its full extent.

Reducing the pumping rate in September and in prior months decreases streamflow depletion compared to constant pumping (fig. 23). Under average recharge conditions, reducing pumping for 1 month lowers September streamflow depletion from 4.4 to $3.1 \mathrm{ft}^{3} / \mathrm{s}$ (scenarios 5 and 6 ), reducing pumping for three months (scenario 7) lowers depletion to $0.8 \mathrm{ft}^{3} / \mathrm{s}$, and reducing pumping for 6 months (scenario 8) drops depletion to $0.3 \mathrm{ft}^{3} / \mathrm{s}$. In terms of percentages, lowering maximum pumping rates to near 0 during September reduces September streamflow depletion by 29 percent, and lowering pumping rates for 3 months (July through September) reduces streamflow depletion during September by 79 percent, as compared to constant pumping. Under dry conditions (low recharge), reducing year-round pumping by 1,3 , and 6 months (scenarios 11, 12, and 13) lowers streamflow depletion from 4.2 to $3.0,1.1$, and $0.5 \mathrm{ft}^{3} / \mathrm{s}$, respectively. 
Table 15. Simulated monthly flow in the Sudbury River under different hypothetical pumping scenarios for the Birch Road wells, east central Massachusetts.

[Scenarios 1, 4, and 9 represent simulations with no Birch Road pumping. Yellow shading highlights months of maximum pumping at a rate of 4.9 cubic feet per second]

\begin{tabular}{|c|c|c|c|c|c|c|c|c|c|c|c|c|c|}
\hline \multicolumn{2}{|c|}{ Scenario } & \multicolumn{12}{|c|}{$\begin{array}{c}\text { Sudbury River flow } \\
\text { (cubic feet per second) }\end{array}$} \\
\hline Number & Name & Jan. & Feb. & Mar. & Apr. & May & June & July & Aug. & Sep. & Oct. & Nov. & Dec. \\
\hline & & \multicolumn{12}{|c|}{ Average recharge conditions } \\
\hline 1 & $\mathrm{n} 33 \mathrm{~m}$ & \multicolumn{12}{|c|}{128.8} \\
\hline 2 & $\mathrm{n} 33 \mathrm{~m} 2$ & \multicolumn{12}{|c|}{123.9} \\
\hline \multicolumn{14}{|c|}{ Transient model scenarios } \\
\hline & & \multicolumn{12}{|c|}{ Average recharge conditions } \\
\hline 3 & $\operatorname{tn} 51 \mathrm{~m}$ & 134.6 & 147.4 & 226.7 & 205.9 & 128.6 & 64.4 & 36.2 & 26.3 & 23.1 & 42.2 & 82.1 & 128.9 \\
\hline 4 & $\operatorname{tn} 50 \mathrm{~m} 7$ & 136.8 & 148.6 & 227.4 & 206.2 & 128.8 & 64.5 & 36.3 & 26.4 & 23.2 & 42.3 & 82.1 & 129.0 \\
\hline 5 & $\operatorname{tn} 71$ & 131.7 & 143.5 & 222.2 & 201.1 & 123.9 & 59.8 & 31.7 & 21.9 & 18.8 & 37.3 & 77.1 & 123.8 \\
\hline 6 & $\operatorname{tn} 72$ & 132.0 & 143.7 & 222.4 & 201.3 & 124.0 & 59.9 & 31.8 & 21.9 & 20.1 & 38.4 & 77.8 & 124.3 \\
\hline 9 & $\operatorname{tn} 80$ & 136.3 & 148.2 & 227.0 & 206.0 & 128.6 & 64.4 & 35.0 & 25.4 & 21.7 & 41.3 & 81.4 & 128.3 \\
\hline 10 & $\operatorname{tn} 81$ & 131.3 & 143.2 & 222.0 & 200.9 & 123.5 & 59.5 & 30.4 & 20.8 & 17.5 & 36.4 & 76.5 & 123.3 \\
\hline 11 & $\operatorname{tn} 82$ & 131.6 & 143.4 & 222.2 & 201.0 & 123.6 & 59.6 & 30.4 & 20.8 & 18.7 & 37.6 & 77.2 & 123.8 \\
\hline 12 & $\operatorname{tn} 83$ & 131.9 & 143.6 & 222.3 & 201.1 & 123.6 & 59.6 & 32.4 & 23.8 & 20.6 & 38.5 & 77.8 & 124.2 \\
\hline 13 & $\operatorname{tn} 84$ & 132.0 & 143.7 & 222.4 & 203.1 & 126.7 & 63.3 & 34.3 & 24.8 & 21.2 & 38.9 & 78.0 & 124.4 \\
\hline
\end{tabular}

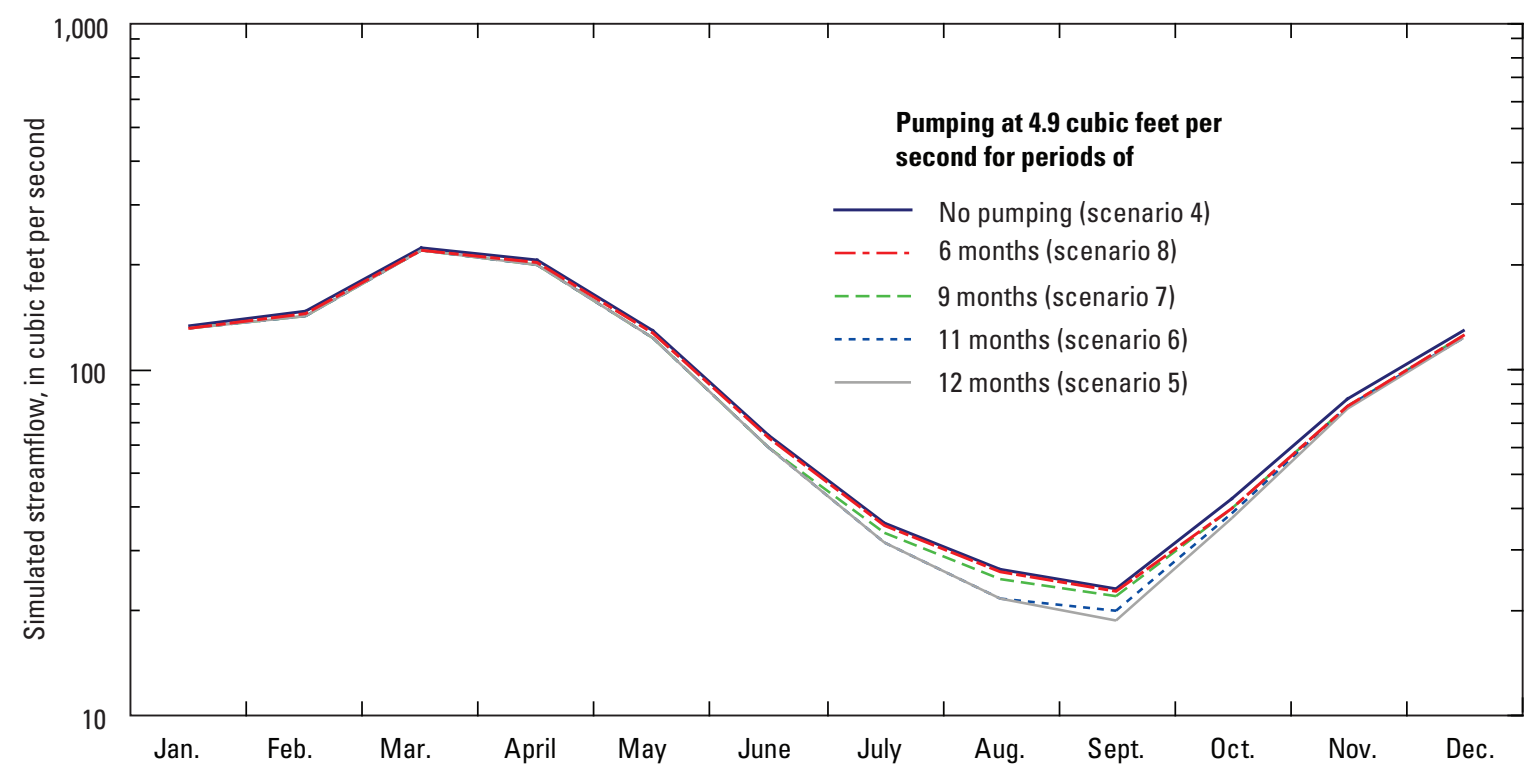

Figure 21. Simulated monthly streamflows in the Sudbury River at the model exit under five hypothetical pumping scenarios for the Birch Road wells, east central Massachusetts. 


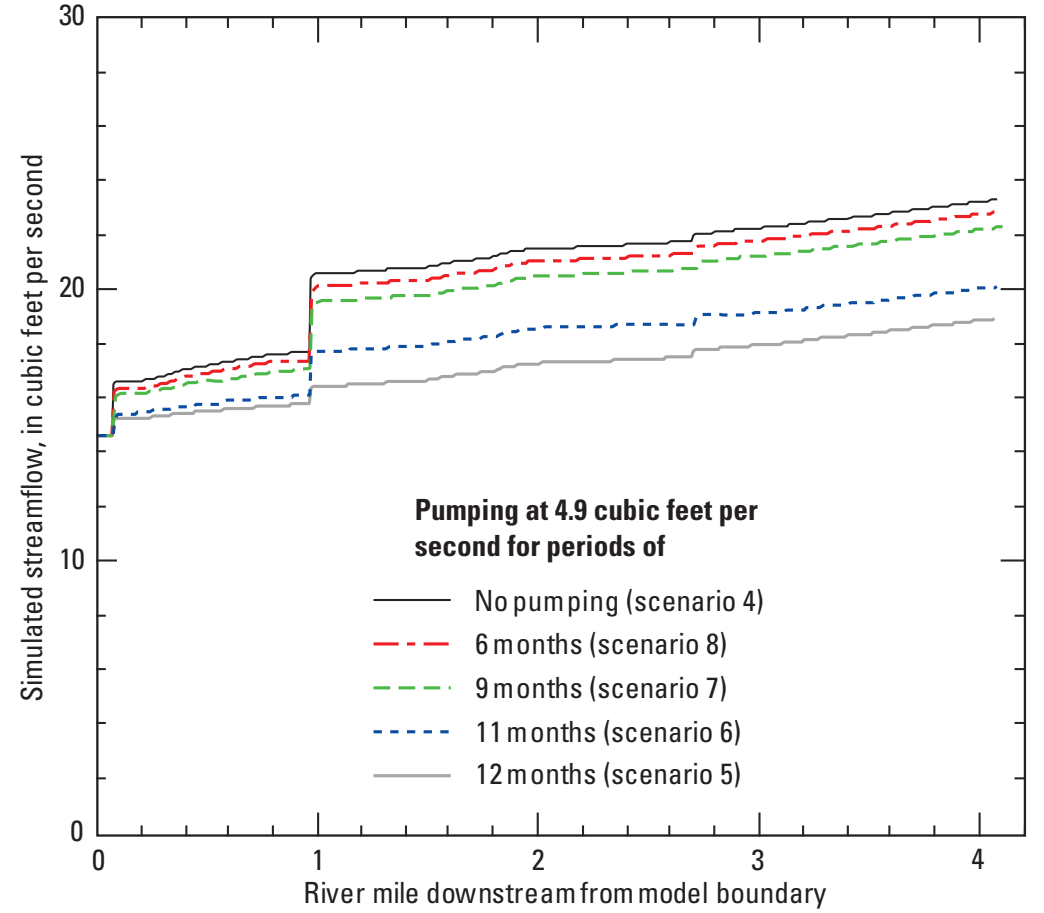

Figure 22. Simulated streamflow along the Sudbury River for the month of September under average recharge rates and various pumping durations at the Birch Road wells, east central Massachusetts.

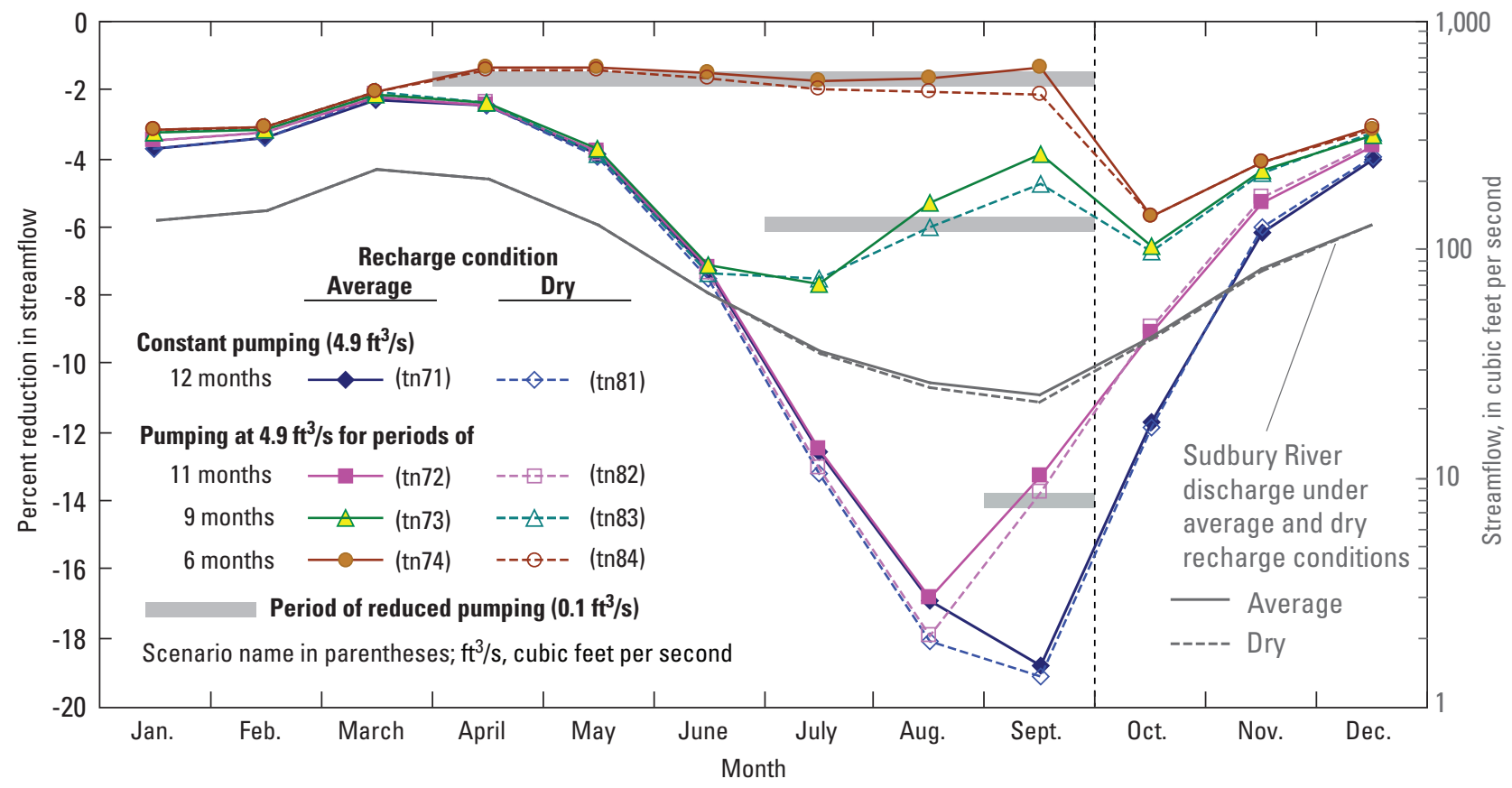

Figure 23. Percent reduction in Sudbury River simulated streamflow at the model exit in response to pumping under average and dry recharge conditions, east central Massachusetts. Streamflow depletion was determined relative to no pumping of the Birch Road wells. 
Under dry conditions, pumping causes a slightly larger percent decrease in streamflow than it does during average recharge conditions (fig. 23). Relative to streamflow under no pumping of the Birch Road wells, constant pumping of these wells at a combined rate of $4.9 \mathrm{ft}^{3} / \mathrm{s}$ decreases streamflow by 18.8 and 19.2 percent under average conditions and dry recharge conditions, respectively (blue lines in fig. 23). When pumping is reduced to near zero during September only, streamflow depletion is 13.3 and 13.7 percent of total streamflow under average conditions and under dry conditions, respectively (purple lines in fig. 23). The streamflow reduction decreases further when pumping is reduced for 3 and 6 months, decreasing to 3.9 and 4.8 percent and 1.3 and 2.2 percent under average and dry recharge conditions, respectively. It should be noted that the percent reduction in streamflow is based on assigned inflow values of 75 percent daily flow duration for each month, representing low-flow conditions. Under average monthly flow conditions, the percent streamflow reductions would be substantially less. Similar patterns of reduced streamflow depletion could be achieved during other periods if reduced pumping rates were applied at other times.

\section{Summary and Conclusions}

The Sudbury River Basin in eastern Massachusetts is an ecologically important resource housing the Great Meadows National Wildlife Refuge, one of the eight National Wildlife Refuges in the State. The Sudbury River is considered stressed by urban development, water withdrawals, and reservoir controls, particularly during periods of low flow when the stream ecology is the most vulnerable to water-management operations. During summer months and periods of low precipitation, the river is primarily fed by groundwater. Because of the river's close hydraulic connection with aquifers, groundwater withdrawals can reduce streamflow during low-flow periods. The Town of Framingham has proposed reactivating groundwater-supply wells along its northern border, near the Sudbury River and the adjacent towns of Wayland, Sudbury, and Natick. This proposal has raised concerns that these withdrawals may further reduce streamflows and adversely affect nearby State and Federal conservation areas and surface-water bodies, particularly Lake Cochituate and Great Meadows National Wildlife Refuge.

In response to these concerns, the U.S. Geological Survey, in cooperation with the Town of Framingham, undertook this investigation to improve the understanding of the hydrogeology of the local aquifer system and the potential effects of the proposed pumping on nearby surface-water features. The study also examined whether groundwater pumping could be managed to minimize the effects of withdrawals during critical low-flow periods. Goals of the investigation included improving understanding of hydrology in the study area, determining rates of flow of water from Lake Cochituate to the Birch Road wells, evaluating potential effects of pumping on surface waters, and assessing the potential for managing pumping to reduce stresses on the hydrologic system.

A numerical groundwater-flow model was developed for the study to simulate the hydrology of the glacial-sediment aquifer in northeastern Framingham and adjacent towns of Wayland, Sudbury, and Natick, by using MODFLOW-NWT. This model was chosen because it provides greater numerical stability than previous versions of MODFLOW for this type of hydrogeologic setting, where model cells are subject to drying because of their small saturated thickness and a fluctuating water table. The model is calibrated with geologic and hydrologic data compiled from prior studies and new data collected during this study. Simulated groundwater levels and streamflows have reasonably good agreement with observed values under various climatic and groundwater pumping stresses.

Steady-state and transient simulations reveal details about the effects of proposed pumping on groundwater and surface water in the vicinity of the Birch Road wells:

- Pumping the Birch Road wells captures groundwater from the surrounding aquifer and induces additional recharge from Lake Cochituate. Under constant (steady-state) pumping, the Birch Road wells induce recharge from Lake Cochituate at a rate of $1.6 \mathrm{ft}^{3} / \mathrm{s}$, which is equal to about 32 percent of the simulated $4.9 \mathrm{ft}^{3} / \mathrm{s}$ pumping rate.

- Groundwater withdrawals reduce flow in the Sudbury River and tributary streams. The Sudbury River downstream of the oxbow is depleted at a rate about equal to the rate of pumping of the Birch Road wells under steady-state conditions.

- Streams respond quickly to changes in pumping. When the Birch Road wells are pumped for 1 month and then stopped, streamflow depletions decrease by about 80 percent within 2 months and by about 90 percent within about 4 months.

- The fast response of surface water to pumping stresses provides the potential to substantially reduce streamflow depletions during periods of low flow by altering pumping rates appropriately for seasonal or anticipated flow conditions. Streamflow depletion during September, typically the month of lowest flow, could be reduced by 29 percent by lowering maximum pumping rates to near zero during September. Lowering pumping rates to near zero for 3 months (July through September) reduces streamflow depletion during September by 79 percent as compared to constant pumping.

- Sensitivity analysis of surface-water response times and rates of induced recharge from Lake Cochituate suggest that model uncertainty could be reduced by better knowledge of the spatial distribution and values of specific yield and hydraulic conductivity of the sand and gravel sediments. 
Model simulations made thus far have improved the understanding of groundwater/surface-water interactions in the study area. Additional data for calibrating the model could further improve the understanding of this complex system and, along with model simulations designed to achieve the most effective pumping strategies, could substantially reduce the effects of withdrawals on surface waters in the area.

\section{References Cited}

Balsam Environmental Consultants, Inc., 1986, Preliminary site investigation report, New England Sand and Gravel Company, Saxonville (Framingham), Massachusetts: Salem, N.H., Balsam Environmental Consultants, Inc., 123 p., accessed September 1, 2012, at http://public.dep. state.ma.us/fileviewer/Rtn.aspx?rtn=3-0000629.

Balsam Environmental Consultants, Inc., 1987, Volume I and II site investigation report, New England Sand and Gravel Company property Saxonville (Framingham), Massachusetts: Salem, N.H., Balsam Environmental Consultants, Inc., 115 p. and 215 p., accessed September 1, 2012, at http://public.dep.state.ma.us/fileviewer/ Rtn.aspx?rtn=3-0000629.

Balsam Environmental Consultants, Inc., 1992, Additional hydrogeologic investigation/ground water modeling, New England Sand and Gravel site, Saxonville, Massachusetts, Volumes I and II: Salem, N.H., Balsam Environmental Consultants, Inc., 123 p., accessed September 1, 2012, at http://public.dep.state.ma.us/fileviewer/ Rtn.aspx?rtn=3-0000629.

Boutt, D.F., Diggins, P., and Mabee, S.B., 2010, A field study (Massachusetts, USA) of the factors controlling the depth of groundwater flow systems in crystalline fractured-rock terrain, Hydrogeology Journal, v. 18, no. 8, p. 1839-1854, DOI: $10.1007 / \mathrm{s} 10040-010-0640-\mathrm{y}$.

Clapp, F.G., 1904, Relations of gravel deposits in the northern part of glacial Lake Charles, Massachusetts: Journal of Geology, v. 12, no. 3, p. 198-214.

DeSimone, L.A., 2004, Simulation of ground-water flow and evaluation of water-management alternatives in the Assabet River Basin, eastern Massachusetts: U.S. Geological Survey Scientific Investigations Report 2004-5114, 133 p. (Also available at http://pubs.usgs.gov/sir/2004/5114/.)

DeSimone, L.A., Walter, D.A., Eggleston, J.R., and Nimiroski, M.T., 2002, Simulation of ground-water flow and evaluation of water-management alternatives in the upper Charles River Basin, eastern Massachusetts: U.S. Geological Survey Water-Resources Investigations Report 02-4234, 93 p. (Also available at http://pubs.er.usgs.gov/publication/ wri024234.)
Doherty, J.E., Hunt, R.J., and Tonkin, M.J., 2010, Approaches to highly parameterized inversion: A guide to using PEST for model-parameter and predictive-uncertainty analysis: U.S. Geological Survey Scientific Investigations Report 2010-5211, 71 p. (Also available at http://pubs.usgs.gov/ $\operatorname{sir} / 2010 / 5211$.)

Friesz, P.J., and Church, P.E., 2001, Pond-aquifer interaction at South Pond of Lake Cochituate, Natick, Massachusetts: U.S. Geological Survey Water-Resources Investigations Report 01-4040, 42 p. (Also available at http://pubs.usgs. gov/wri/wri014040/.)

Gay, F., 1981, Hydrologic data of the Lake Cochituate drainage basin, Framingham-Natick, Massachusetts: U.S. Geological Survey Open-File Report 82-342, 70 p. (Also available at http://pubs.er.usgs.gov/publication/ofr82342/.)

Gay, F., 1985, Estimated water and nutrient inflows and outflows, Lake Cochituate, eastern Massachusetts, 1977-79: U.S. Geological Survey Water Resources Investigations Report 84-4315, 59 p. (Also available at http://pubs.er.usgs. gov/publication/wri844315/.)

Gleeson, T., Alley, W.M., Allen, D.M., Sophocleous, M.A., Zhou, Y., Taniguchi, M., and VanderSteen, J., 2011, Towards sustainable groundwater use - setting long-term goals, backcasting, and managing adaptively: Ground Water, v. 50, no. 1, p. 19-26, accessed September 1, 2012, at http://onlinelibrary.wiley.com/doi/10.1111/ j.1745-6584.2011.00825.x/full.

Goldsmith, Richard, 1991, Stratigraphy of the MilfordDedham Zone, eastern Massachusetts-An Avalonian Terrane, in Hatch, N.L., Jr., ed., 1991, The bedrock geology of Massachusetts: U.S. Geological Survey Professional Paper 1366-E, 62 p. (Also available at http://pubs.er.usgs. gov/publication/pp1366EJ.)

GZA GeoEnvironmental, Inc., Jacobs Associates, and Sverdrup Civil, Inc., 1995, MWRA contracts 6054, 6055, and 6059, Geotechnical data report, Metrowest watersupply tunnel, construction packages 1, 2, and 3: v. III of IX, variously paged.

Haley \& Aldrich, 1996, Response action outcome statement, 1455 Concord Street, Framingham, Massachusetts: Cambridge, Mass., Haley \& Aldrich, Inc., Mass DEP RTN-3-13162, 183 p., accessed September 1, 2012, at http://public.dep.state.ma.us/fileviewer/Rtn. aspx?rtn=3-0013162.

Hanson, B.P., and Simcox, A.C., 1994, Yields of bedrock wells in Massachusetts: U.S. Geological Survey Water-Resources Investigations Report 93-4115, 43 p. (Also available at http://pubs.er.usgs.gov/publication/wri934115/.) 
Harbaugh, A.W., 1990, A computer program for calculating subregional water budgets using results from the U.S. Geological Survey modular three-dimensional ground-water flow model: U.S. Geological Survey Open-File Report 90-392, 46 p. (Also available at http://pubs.er.usgs.gov/ publication/ofr90392/.)

Harbaugh, A.W., Banta, E.R., Hill, M.C., and McDonald, M.G., 2000, MODFLOW-2000, the U.S. Geological Survey modular groundwater model-User guide to modularization concepts and the ground-water flow process: U.S. Geological Survey Open-File Report 00-92, 121 p. (Also available at http://pubs.er.usgs.gov/publication/ofr200092/.)

Hill, M.C., Banta, E.R., Harbaugh, A.W., and Anderman, E.R., 2000, MODFLOW-2000, the U.S. Geological Survey modular ground-water model- - User guide to the observation, sensitivity, and parameter-estimation processes and three post-processing programs: U.S. Geological Survey Open-File Report 00-184, 210 p. (Also available at http://pubs.er.usgs.gov/publication/ofr00184/.)

Hunt, R.J., Haitjema, H.M., Krohelski, J.T., and Feinstein, D.T., 2003, Simulating ground water-lake interactionsApproaches and insights: Ground Water, v. 41, no. 2, p. 227-237.

Ibs-von Seht, Malte, and Wohlenberg, Jtirgen, 1999, Microtremor measurements used to map thickness of soft sediments: Bulletin of the Seismological Society of America, v. 89 , p. $250-259$.

IEP, Inc., 1983, Diagnostic feasibility study Dudley Pond Wayland, Massachusetts, Town of Wayland Massachusetts: Surface Water Quality Study Committee, April 1983, 145 p.

Kennedy, E.J., 1983, Techniques of water-resources investigations of the United States Geological Survey: chap. Al3, book 3, Computation of continuous records of streamflow, p. 47. (Also available at http://pubs.er.usgs.gov/publication/ twri03A13/.)

Koteff, Carl, and Pessl, Fred, 1981, Systematic ice retreat in New England: U.S. Geological Survey Professional Paper 1179, 20 p. (Also available at http://pubs.er.usgs.gov/ publication/pp1179/.)

Lane, J.W., White, E.A., Steele, G.V., and Cannia, J.C., 2008, Estimation of bedrock depth using the horizontal-to-vertical $(\mathrm{H} / \mathrm{V})$ ambient-noise seismic method, in Symposium on the Application of Geophysics to Engineering and Environmental Problems, April 2008, Philadelphia, Pa., Proceedings: Denver, Colo., Environmental and Engineering Geophysical Society, $13 \mathrm{p}$.

Mabee, S.B., Curry, P.J., and Hardcastle, K.C., 2002, Correlation of lineaments to groundwater inflows in a bedrock tunnel: Ground Water, v. 40, no. 1, p. 37-43.
MassGIS, 2003, Digital orthophoto elevation, Commonwealth of Massachusetts Executive Office for Administration and Finance: accessed November 22, 2010, at http://www.mass.gov/mgis/p.htm.

Massachusetts Department of Conservation and Recreation (MassDCR), 2006, Public access management plan update-Quabbin Reservoir watershed system: 18 p., accessed March 22, 2012, at http://www.mass.gov/dcr/ watersupply/watershed/documents/quabbinaccessch1.pdf.

Masterson, J.P., Carlson, C.S., and Walter, D.A., 2009, Hydrogeology and simulation of groundwater flow in the Plymouth-Carver-Kingston-Duxbury aquifer system, southeastern Massachusetts: U.S. Geological Survey Scientific Investigations Report 2009-5063, 110 p. (Also available at http://pubs.usgs.gov/sir/2009/5063/.)

Merritt, M.L., and Konikow, L.F., 2000, Documentation of a computer program to simulate lake-aquifer interaction using the MODFLOW ground-water flow model and the MOC3D solute-transport model: U.S. Geological Survey WaterResources Investigations Report 00-4167, 146 p. (Also available at http://pubs.er.usgs.gov/publication/wri004167.)

Nelson, A.E., 1974a, Bedrock geologic map of the Natick quadrangle, Middlesex and Norfolk Counties, Massachusetts: U.S. Geological Survey Geologic Quadrangle Map GQ-1208, scale 1:24,000, accessed September 1, 2012, at http://ngmdb.usgs.gov/Prodesc/ proddesc_10746.htm.

Nelson, A.E., 1974b, Surficial geologic map of the Framingham quadrangle, Middlesex and Worcester Counties, Massachusetts: U.S. Geological Survey Geologic Quadrangle Map GQ-1176, scale 1:24,000, accessed September 1, 2012, at http://ngmdb.usgs.gov/Prodesc/ proddesc_10691.htm.

Nelson, A.E., 1974c, Surficial geologic map of the Natick quadrangle, Middlesex and Norfolk Counties, Massachusetts: U.S. Geological Survey Geologic Quadrangle Map GQ-1151, scale 1:24,000, accessed September 1, 2012, at http://maps.ngmdb.us/dataviewer/.

Nelson, A.E., 1975, Bedrock geologic map of the Framingham quadrangle, Middlesex and Worcester Counties, Massachusetts: U.S. Geological Survey Geologic Quadrangle Map GQ-1274, scale1:24,000, accessed September 1, 2012, at http://maps.ngmdb.us/dataviewer/.

Niswonger, R.G., Panday, S., and Ibaraki, M., 2011, MODFLOW-NWT, A Newton formulation for MODFLOW-2005: U.S. Geological Survey Techniques and Methods 6-A37, $44 \mathrm{p}$. (Also available at http://pubs.er.usgs.gov/publication/ tm6A37/.) 
Niswonger, R.G., and Prudic, D.E., 2005, Documentation of the Streamflow-Routing (SFR2) package to include unsaturated flow beneath streams-A modification to SFR1: U.S. Geological Survey Techniques and Methods 6-A13, $50 \mathrm{p}$. (http://pubs.er.usgs.gov/publication/tm6A13)

Poeter, E.P., Hill, M.C., Banta, E.R., Mehl, Steffen, and Christensen, Steen, 2005, UCODE_2005 and six other computer codes for universal sensitivity analysis, calibration, and uncertainty evaluation: U.S. Geological Survey Techniques and Methods 6-A11, 283 p.

SEA Consultants, Inc., 1992, Report on prolonged pumping test for the Concord/Sudbury river basin Cochituate well supply-water supply feasibility study, Framingham, Massachusetts: SEA Consultants, Inc., Cambridge, Mass., $38 \mathrm{p}$.

SEA Consultants, Inc., 2008, Source final report, Birch Road well re-activation, Framingham, Massachusetts: SEA Consultants, Inc., Cambridge, Mass., 73 p.

SEA Consultants, Inc., 2009, Final environmental impact report and notice of project change, EEA No. 14197, for Birch Road well site reactivation and water treatment plant, Town of Framingham: SEA Consultants, Inc., Cambridge, Mass., 201 p.

Sovereign Consulting, Inc., 2009, Phase I initial site investigation, tier classification, and phase II scope of work-Mass. DEP RTN 3-27985: Sovereign Consulting, Inc., Mansfield, Mass., accessed May 2011, at http://public.dep.state.ma.us/ fileviewer/Default.aspx?formdataid=0\&documentid $=51762$.
Stone, J.R., and Stone, B.D., 2006, Surficial geologic map of the Clinton-Concord-Grafton-Medfield quadrangle area in east central Massachusetts: U.S. Geological Survey Open-File Report 2006-1260-A, 1 pl. (Also available at http://ngmdb.usgs.gov/Prodesc/proddesc_80659.htm.)

URS Corporation, 2003, Response action outcome statement, New England Sand and Gravel site, Saxonville, Massachusetts, RTN 3-0629, HQ AFCEE: URS Corporation, Portland, Maine, $62 \mathrm{p}$.

Wayland Wellhead Protection Committee, and Young, B.W., 2011, Wayland wellhead protection plan: Wayland, Mass., Wayland Wellhead Protection Committee, 86 p., accessed September 1, 2012, at http://www.wayland.ma.us/ Pages/WaylandMA_DPW/WellheadProtectionPlan6MB2June2011.pdf.

Wilmott, C.J., 1977, WATBUG-A Fortran IV algorithm for calculating the climatic water budget: Climatology, v. 30, p. 2-4.

Zarriello, P.J., Parker, G.W., Armstrong, D.S., and Carlson, C.S., 2010, Effects of water use and land use on streamflow and aquatic habitat in the Sudbury and Assabet river basins, Massachusetts: U.S. Geological Survey Scientific Investigations Report 2010-5042, 160 p. (Also available at http://pubs.usgs.gov/sir/2010/5042/.)

Zen, E-an, Goldsmith, Richard, Ratcliffe, N.M., Robinson, Peter, Stanley, R.S., Hatch, N.L., Shride, A.F., Weed, E.G.A., and Wones, D.R., 1983, Bedrock geologic map of Massachusetts: U.S. Geological Survey, scale 1:250,000, accessed September 1, 2012, at http://ngmdb.usgs.gov/ Prodesc/proddesc_16357.htm. 
THIS PAGE INTENTIONALLY LEFT BLANK 
Prepared by the Pembroke Publishing Service Center.

For more information concerning this report, contact:

Director

U.S. Geological Survey

Massachusetts-Rhode Island Water Science Center

10 Bearfoot Road

Northborough, MA 01532

dc_ma@usgs.gov

or visit our Web site at:

http://ma.water.usgs.gov 


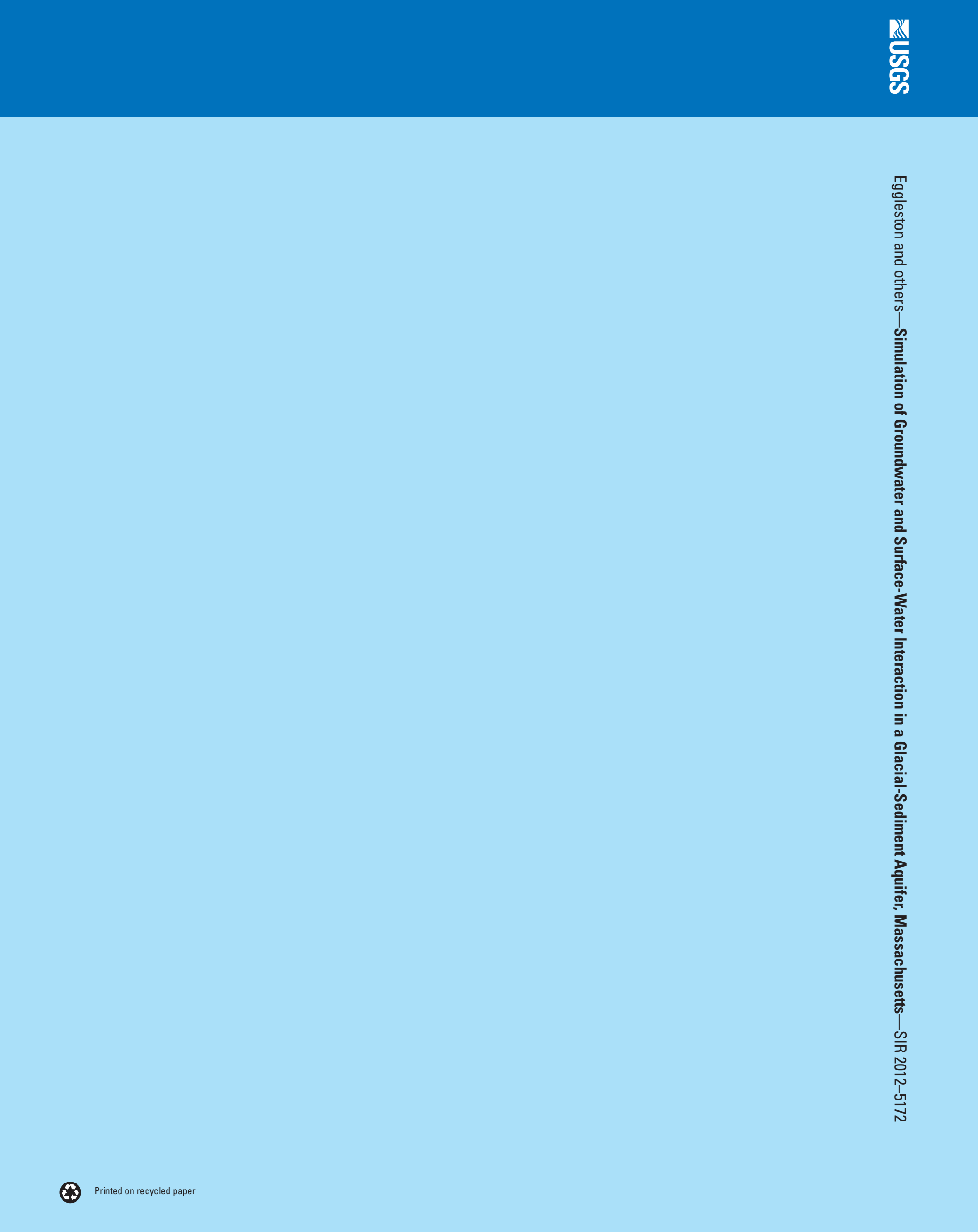

